
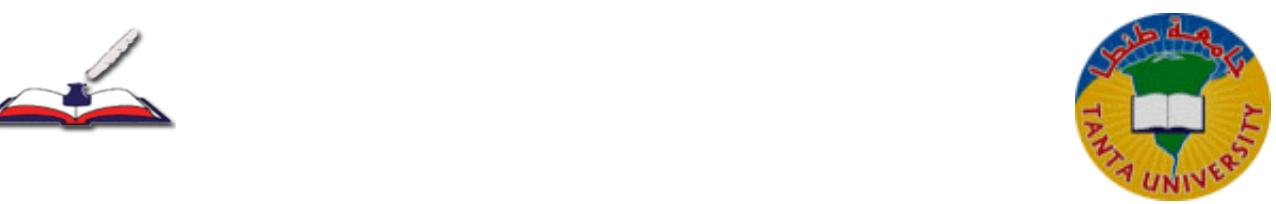

الصوفية وموقفهم من السنة النبوية

إعداد

د/ عطية بن نوري بن محمد آل خلف الفقيه الشريف

أستاذ الحديث و علومه بالكلية الجامعية

بمحافظة القنفذة فرع جامعة أم القرى

المجلد (9 ؟) العدد (الأول) الجزء (الثاني) يناير / ^l • r م 


\section{$\wedge r$}

\section{بسم الله الرحمز الرهيم}

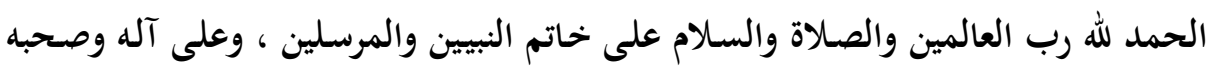

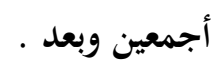
فهذا بحث بعنوان ( الصوفية وموقفهم من السنة النبوية ) وإليك بيان خطة البحث وهي كالتالي:

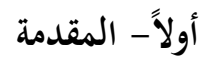

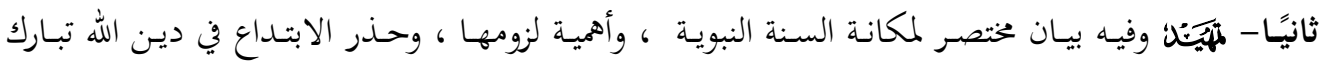

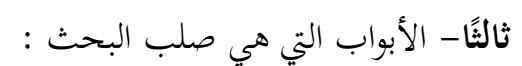
الباب الأول: الصوفية ونشأتها الأولى ، وفيه ثمانية فصول :

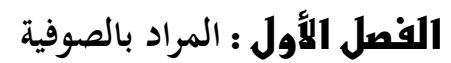
الفصل الثاني : نشأتها الأولى الفى الفيه

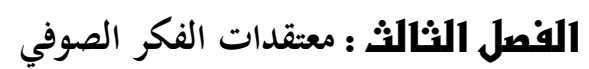

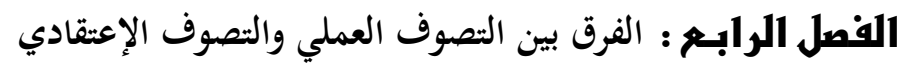
الفصل الفامسر : علاقة الصوفية بالشيعة

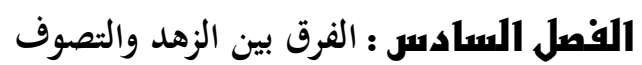
الفصل السابر : مصطلحات الصوفية الفصل الثامز : مصادر التلقي عند الصوفية الباب الثاني : موقف الصوفية من السنة النبوية ، وفيه فصول : 1الفصل الأول : موقف الصوفية من الصحابة

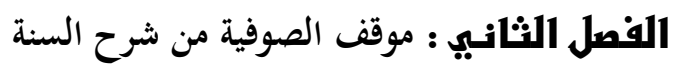
الفصل الثالث : موقف الصوفية من إسناد الحديث

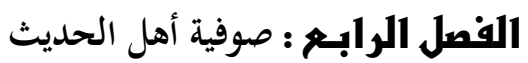
الفصل الخامسر : شبه الصوفية الفصل السادسر : موقف علماء السنة من التصوف الفاتمة : وبهما أهم التوصيات

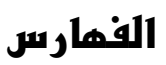
فهر ست المصادر فهر ستت المواضيخ 
الحمد لله رب العالمين، شرع لنا الدين القويم وهدانا صراطه المستقيم، أرسل إلينا خير رسله

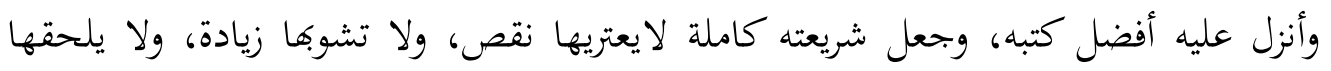

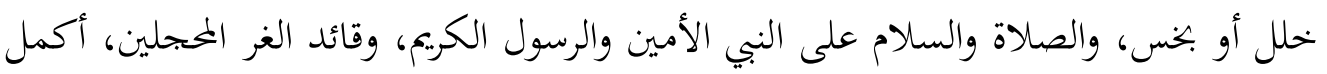

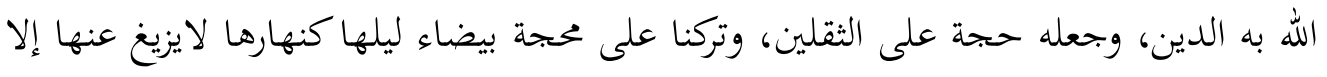

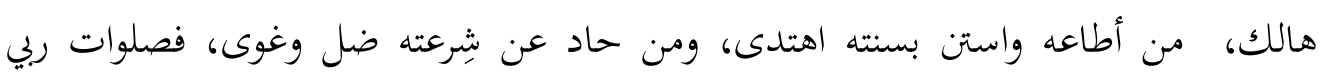

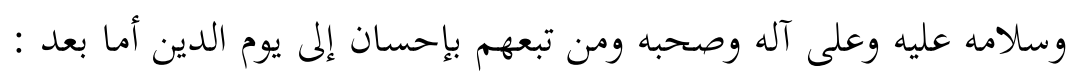

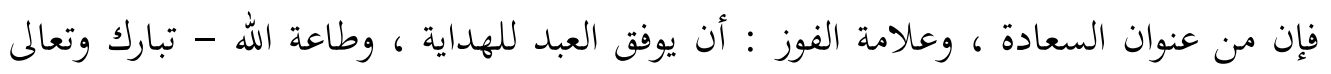

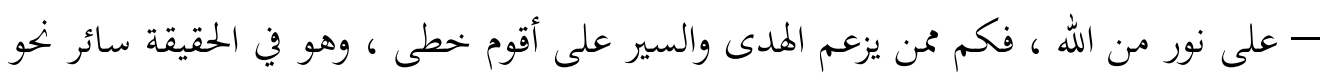

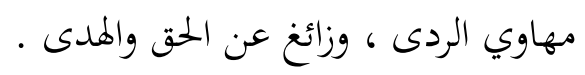

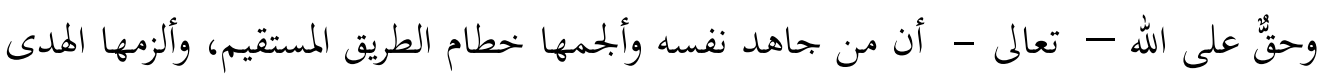

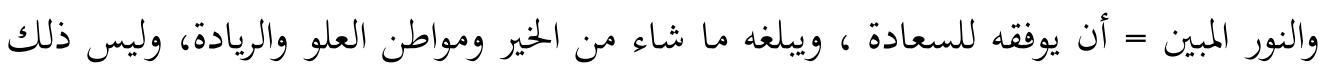

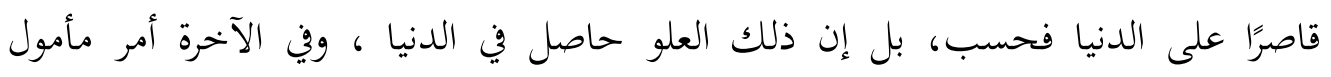
،وصاحبه بالمكرمات موصول.

وإن من سيئ الأمور وشرها : أن يقع العبد في شباك إبليس ، وغوائله التي لا منتهى لها ولا إلا

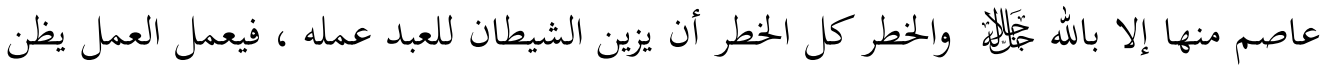

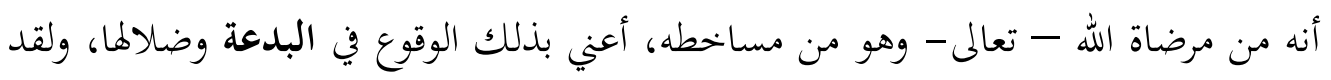

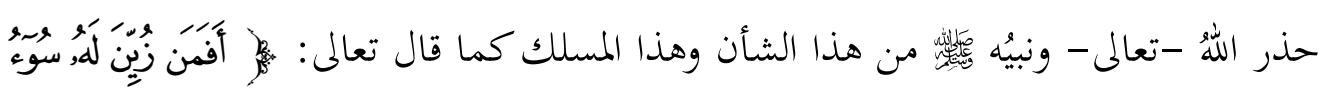

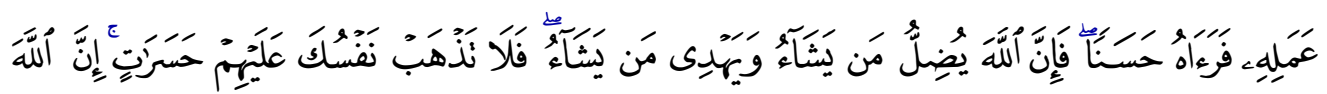

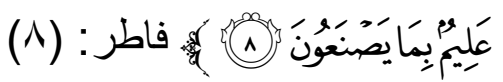

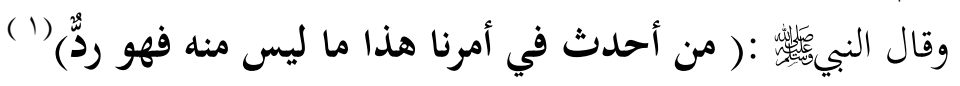

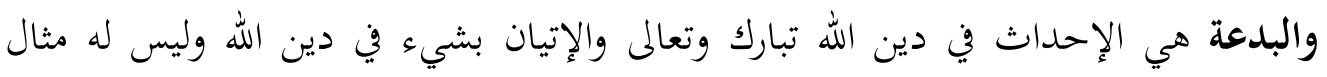

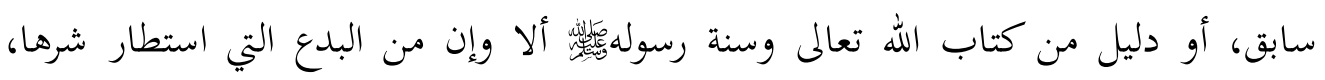
وعظم خطرها، بدعة التصوف هذه الضلالة التي بدأت في عصور مبكرة، على نوع من التعبد

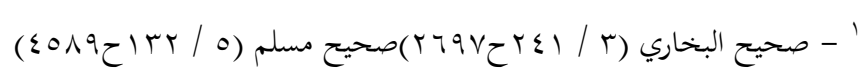




\section{^०}

والتقشف في أمر الدنيا، ثم انخرفت الأمور ، وابتعد أقوام عن جيل الهدى، وشطت بهم الآراء الاجتهادية في العبادة، حتى وقعوا فيما يشبه الغلو الذي هو في أصله باب يصطاد الشيطان

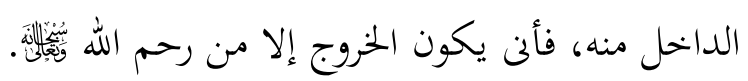

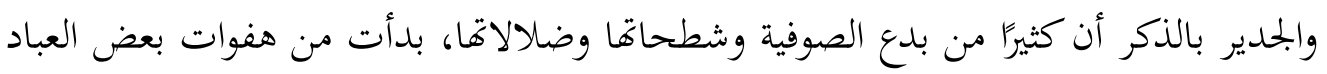

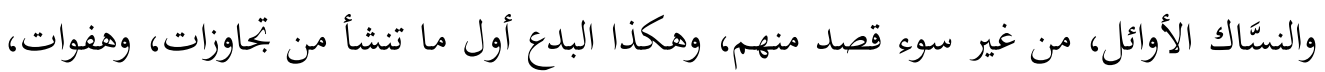

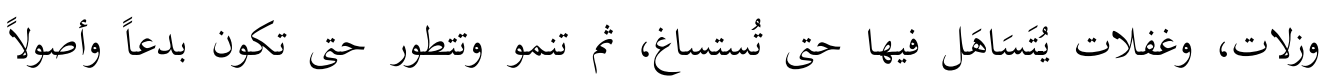
ومناهج في سبيل الضلالة والغواية.

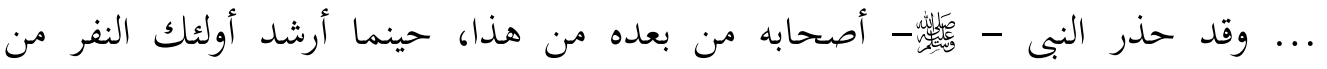

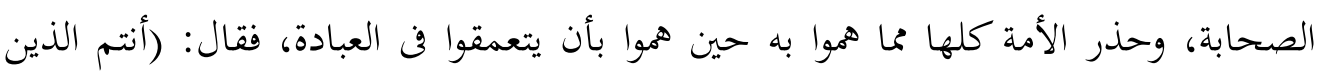

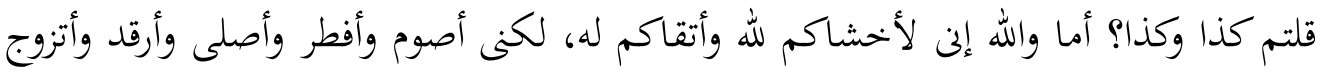

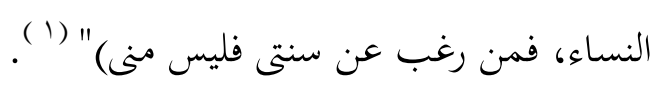

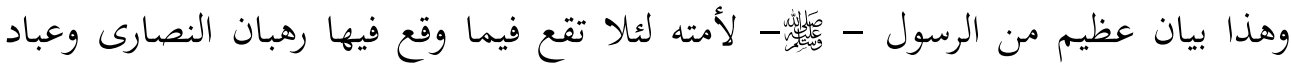

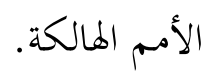

وفن القرن الثانى وما بعده زادت البدع في العبادات وغيرها لدى طائفة من العباد والنساك

$$
\text { والجهلة، وأنكر عليهم السلف ذلك. }
$$

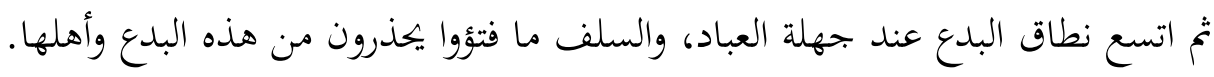

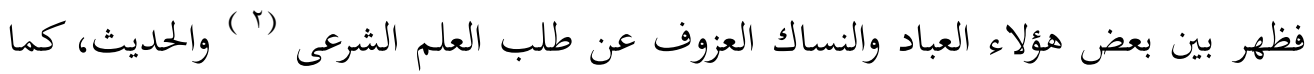

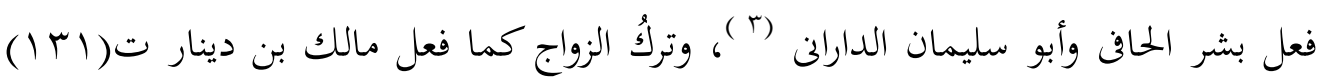

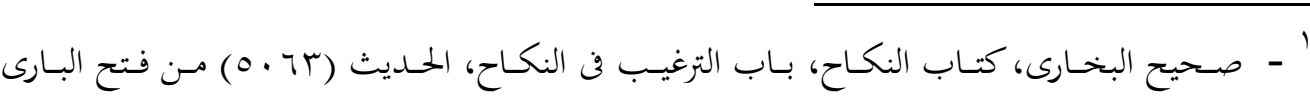

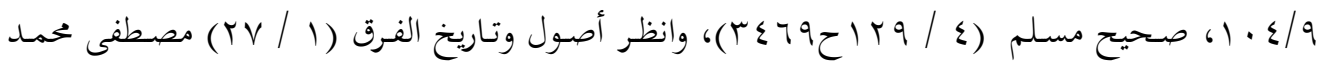

$$
\begin{aligned}
& \text { مصطفى . }
\end{aligned}
$$

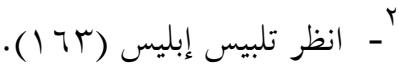

$$
\begin{aligned}
& \text { ك }
\end{aligned}
$$

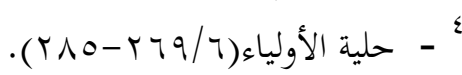




\section{$\wedge 7$}

والعزلةُ ومصاحبةُ الكلابِ كما فعل مالك بن دينار كذلك.

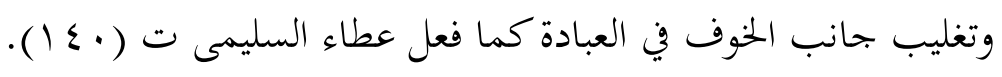

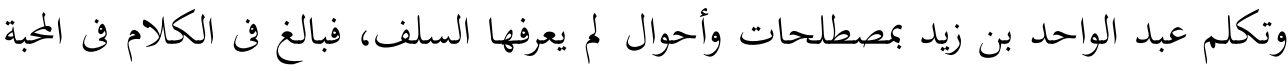

والشوق والأنس على نحو لم ترد به السنة، واتكأت عليه الصوفية المنحرفة فيما بعد.

$$
\text { وتكلمت رابعة العدوية ت (• (1) اهـ) بما يشبه الحلول). }
$$

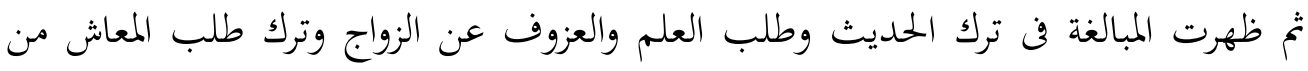

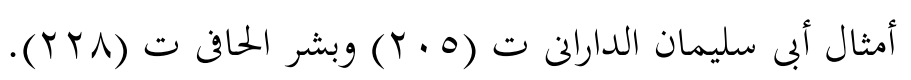

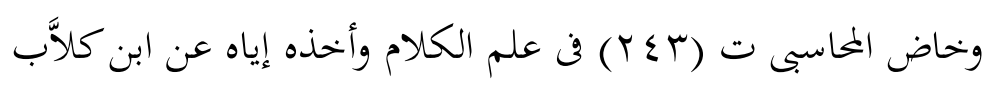$$
\text { وتكلم السرى السَّقطى ت (Yor) فن مسألة (الحقائق والإشارات). }
$$

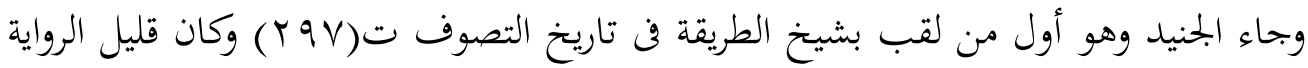

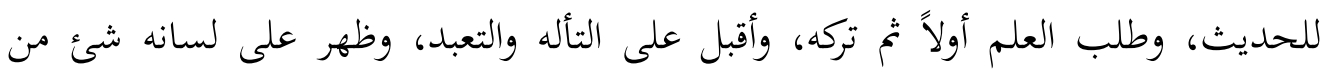

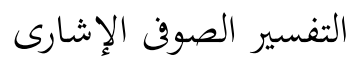

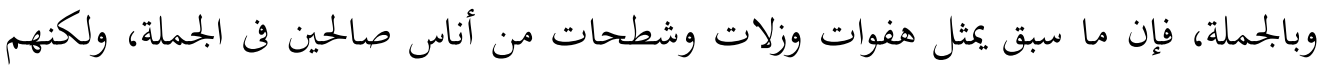

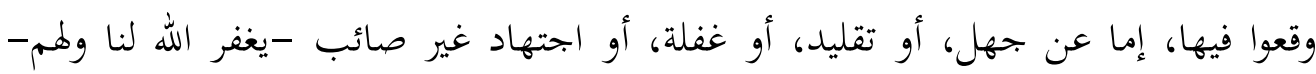

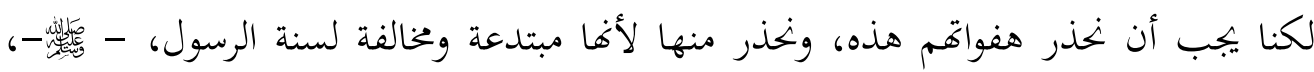

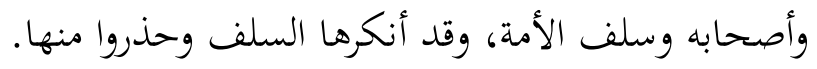

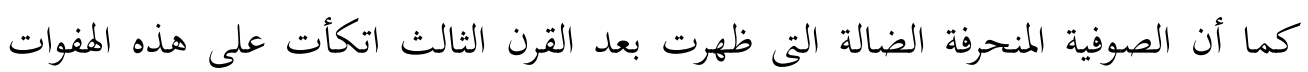

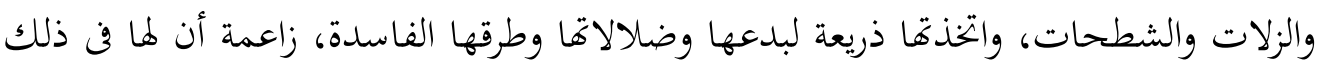
قدوة من الصالحين، وهذا من تلبيس الشيطان وأتباعه (1).

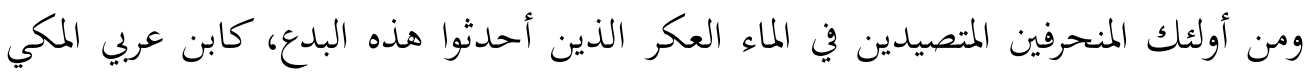

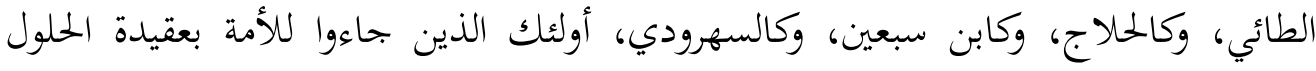

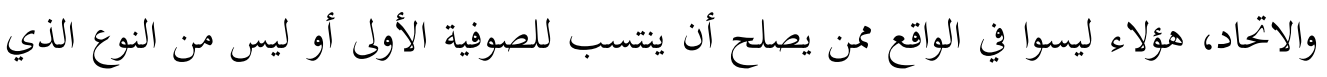

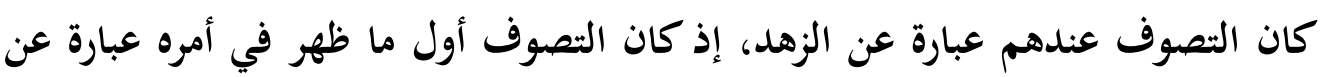


AV

الزهد والانقطاع عن الدنيا، ولم يختلط بالمفاهيم الفلسفية؛ إلا في وقت متأخر؛ ولهذا

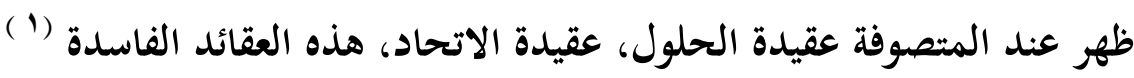




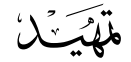

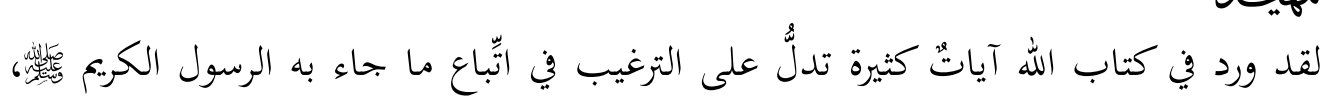
والحث على ذلك والتحذير من مخالفة الرسول ثلئلي فيما جاء به من الحق والهدى والوقوع في

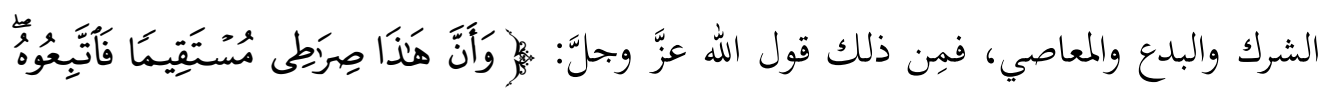

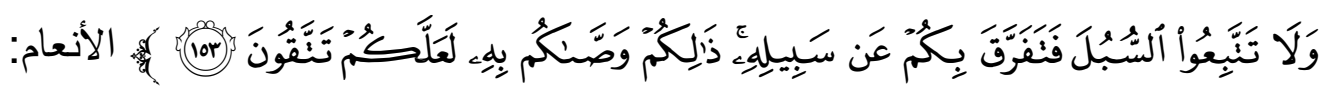

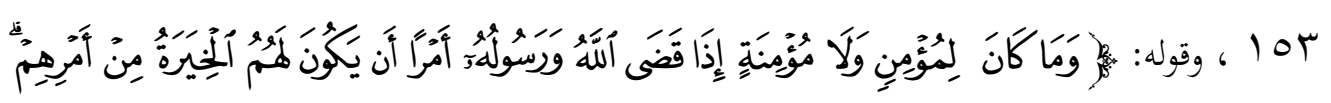

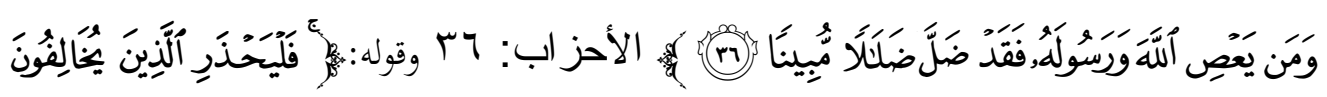

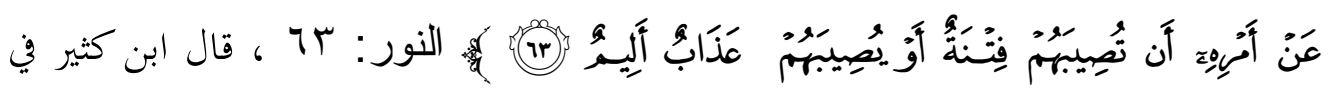

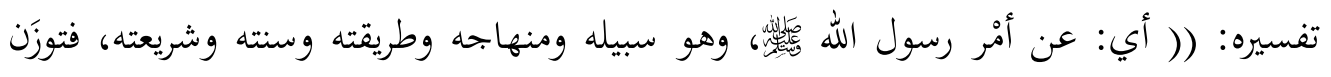

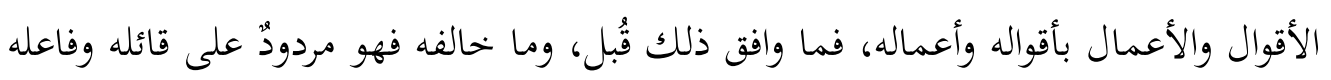

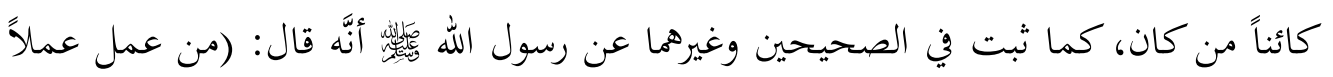
ليس عليه أمرنا فهو رد) (1)، أي: فليحذر وليخش مَن خالف شريعة الرسول باطناً وظاهراً (آَن

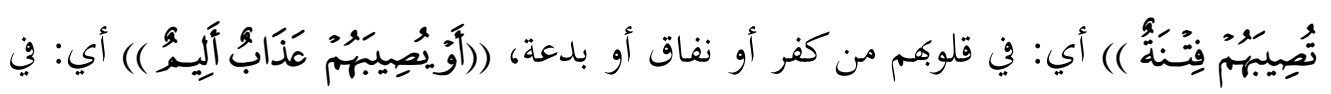

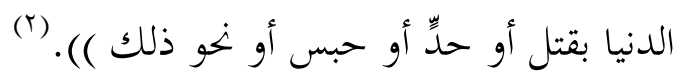

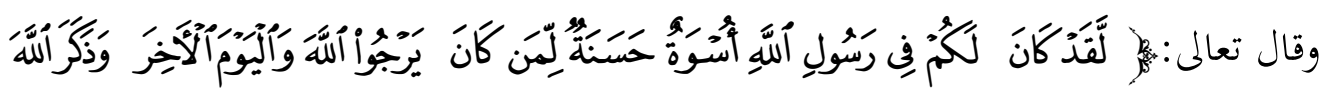

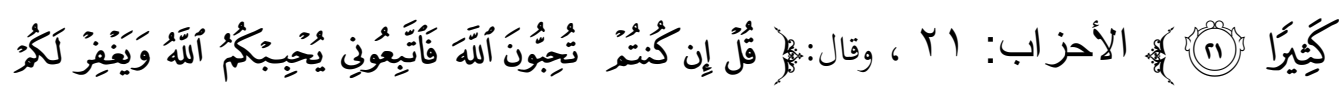

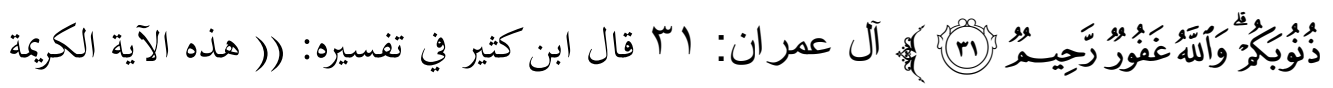

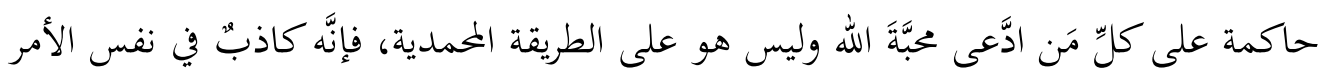

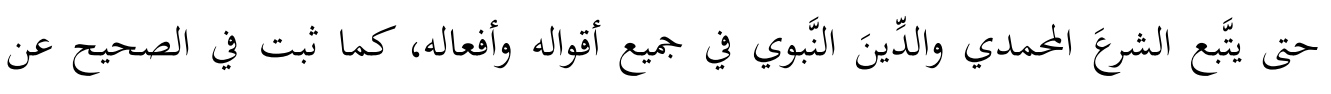

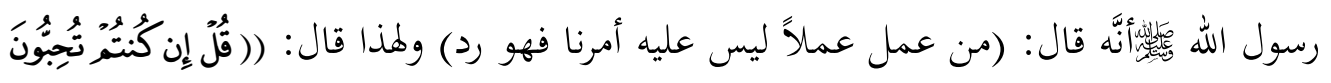

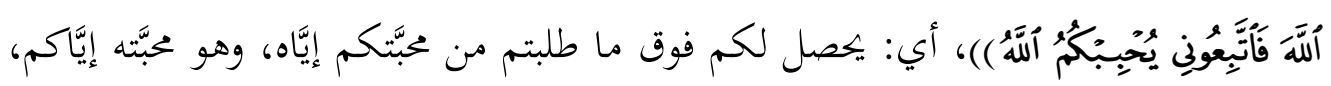

' - مبق تخريجه .

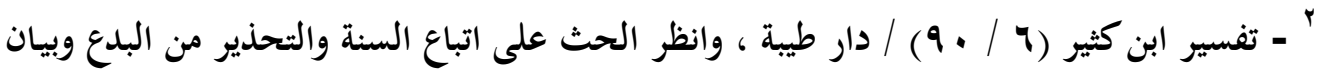
خطرها (1 / • (1) عبد المحسن البدر . 


\section{9}

وهو أعظم من الأول، كما قال بعض العلماء الحكماء: ليس الشأن أن تُحِبَّ، إنَّما الشأن أن

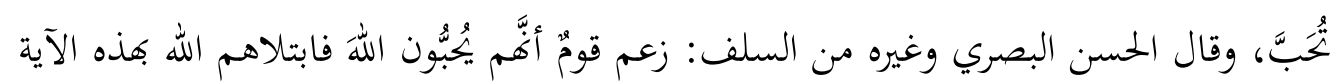

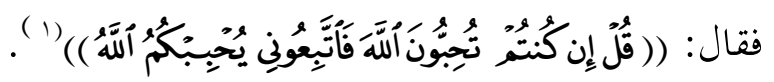

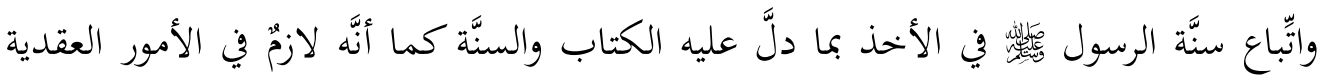

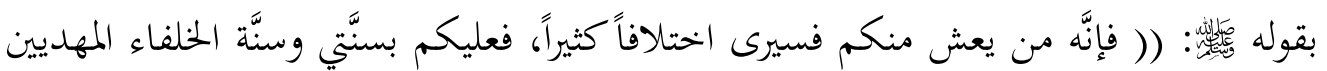

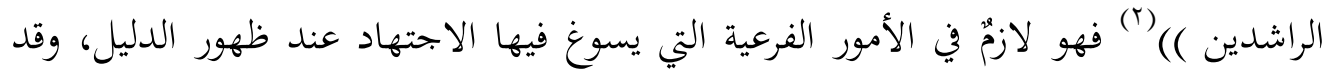

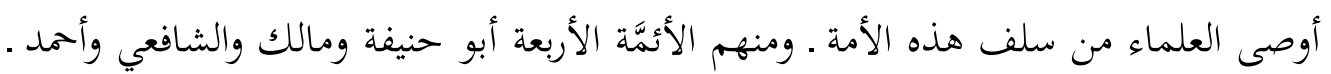

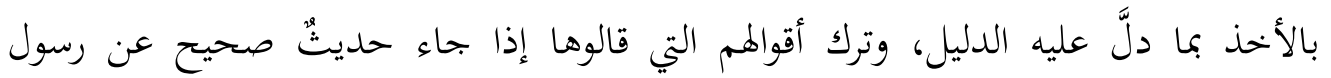

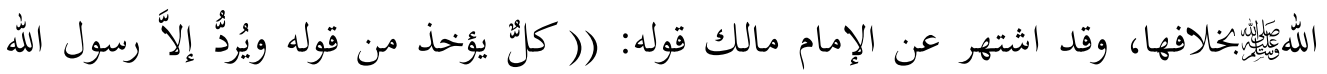

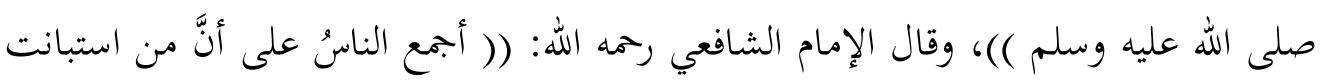

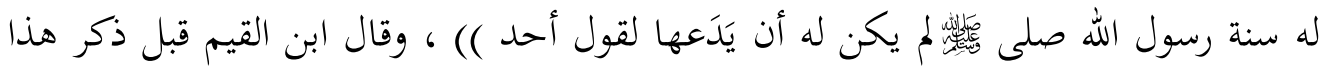

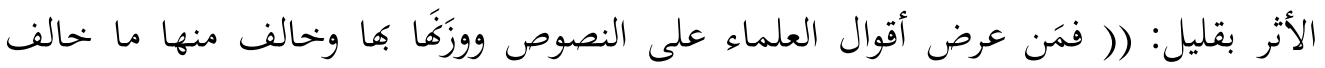

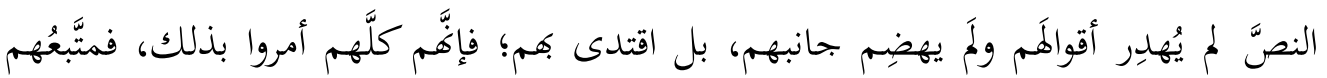

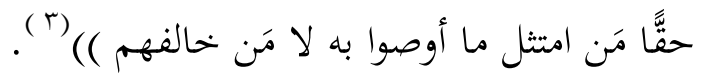

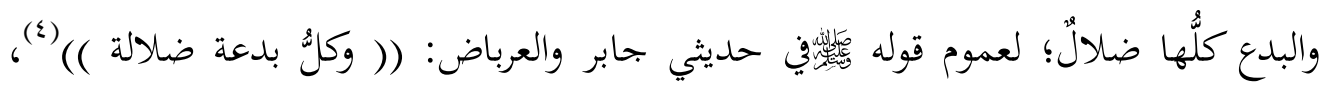

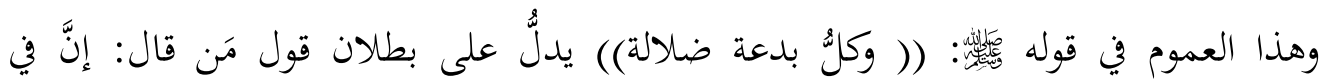

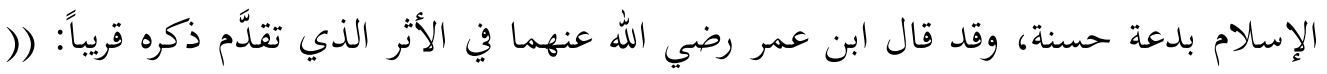

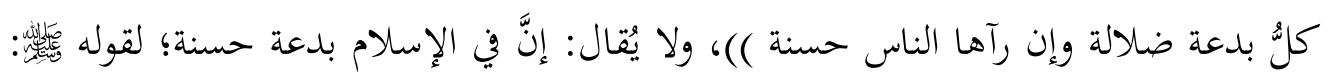

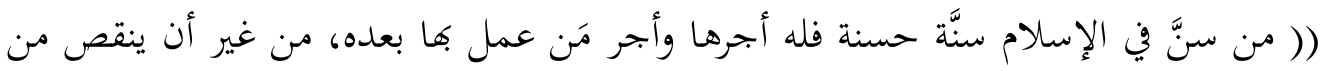

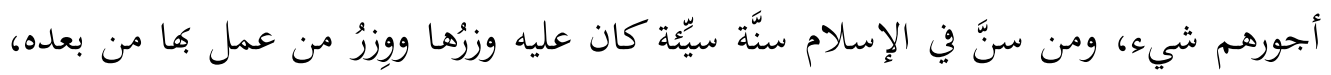

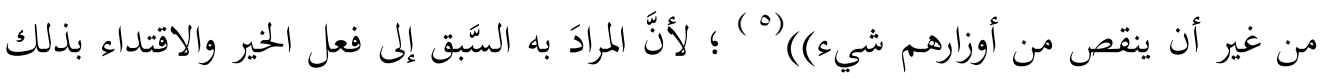

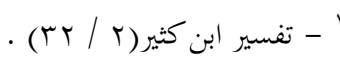

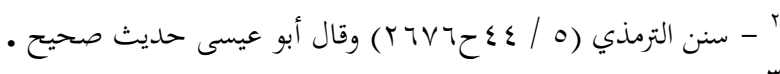

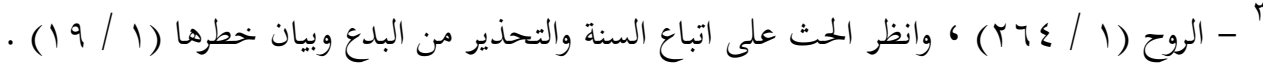

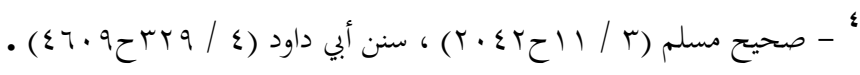

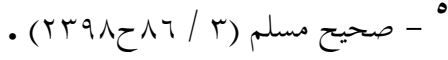




\section{9.}

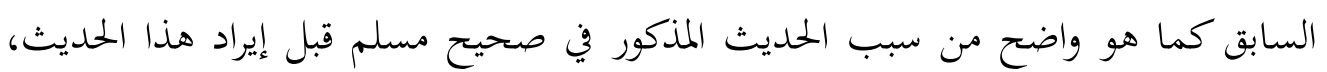

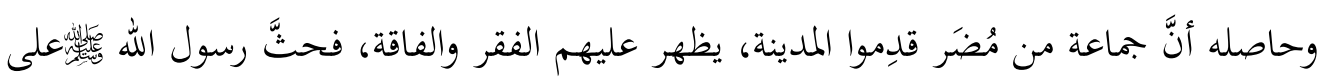

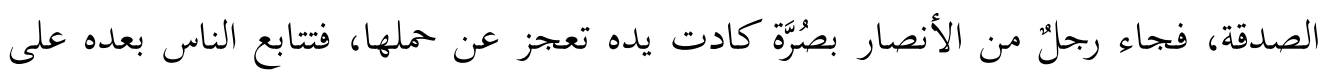

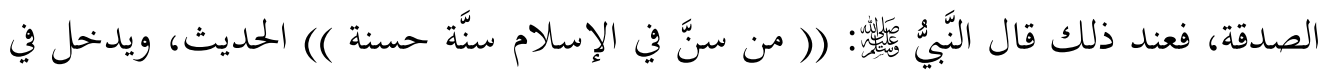

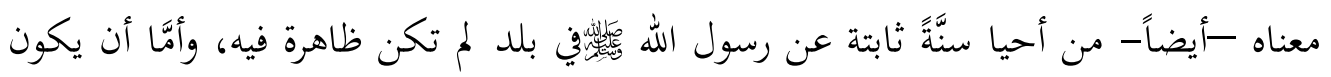

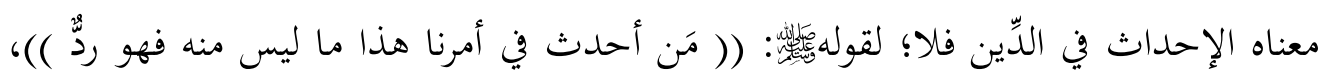

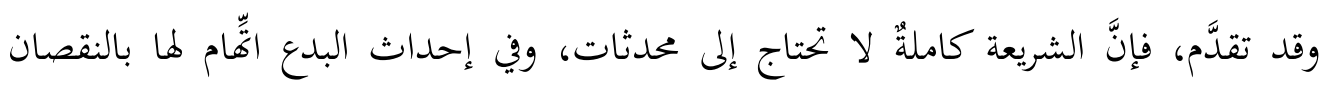

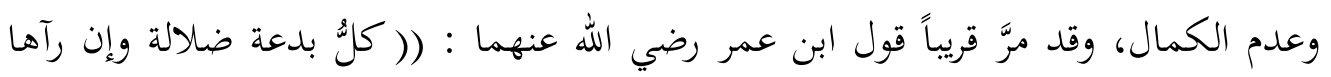
الناس حسنة ))، وقول مالك: (( من ابتدع في الإسلام بدعة يراها حسنة فقد زعم أنَّ محمداً

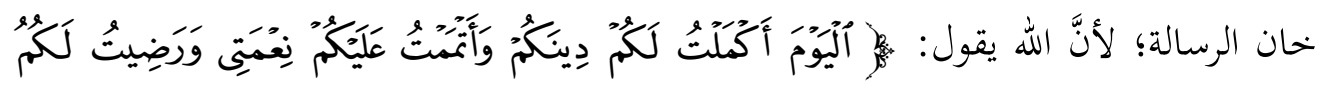

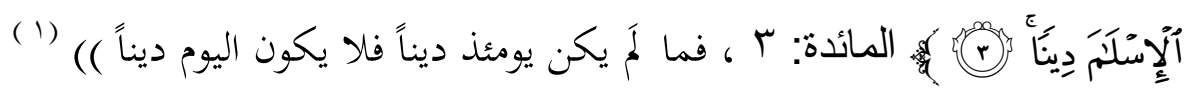

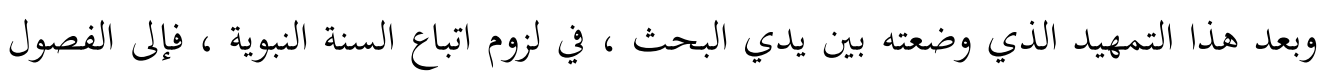

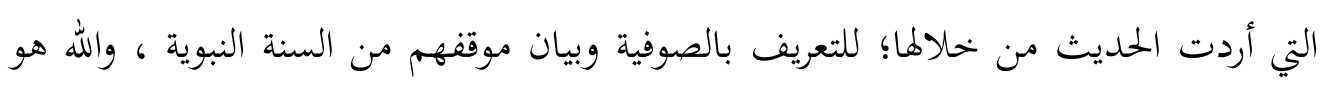
المستعان ولا حول ولا قوة إلا بالله. 


\section{الباب الأول}

الصوفية ونشأتها الأولى وفيه ثمانية فصول : 
الفصل الأول : المراد بالصوفية

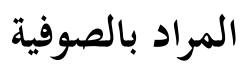

حينما نأتي إلى تعريف الصوفية وبيان المراد بها ، بند كمًا هائلاً من التعريفات والتوضيحات التهات

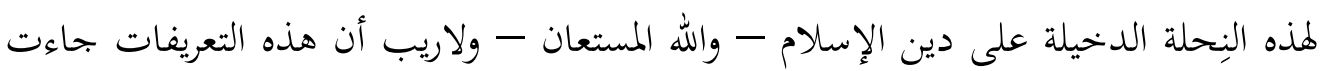

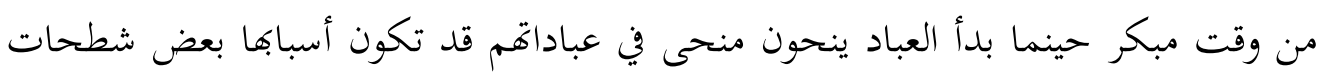

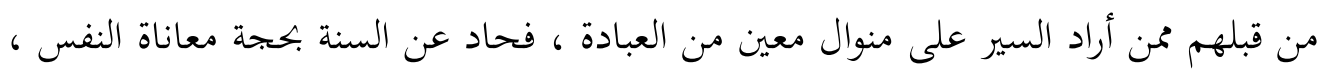

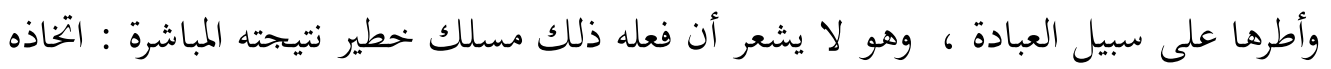

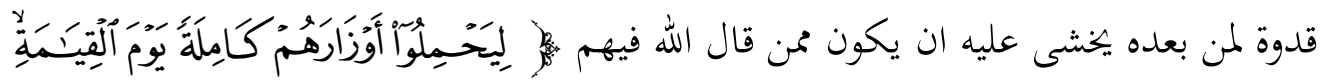

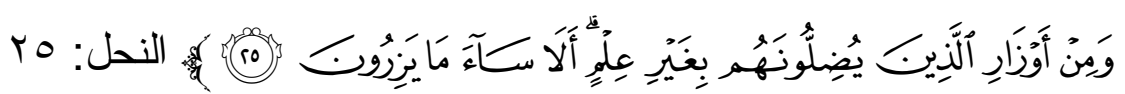

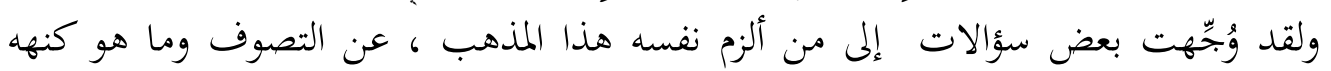

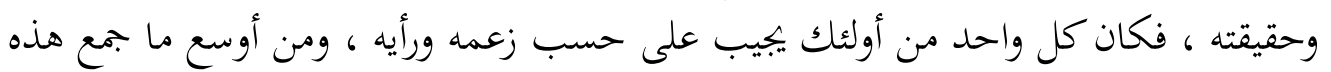

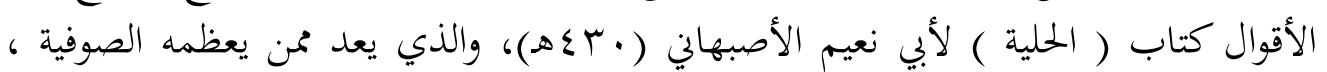
وينتسبون إليه .

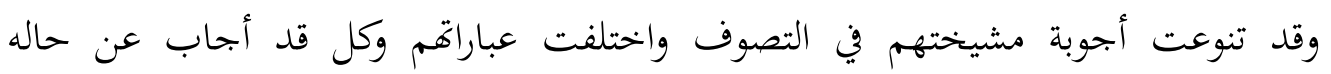

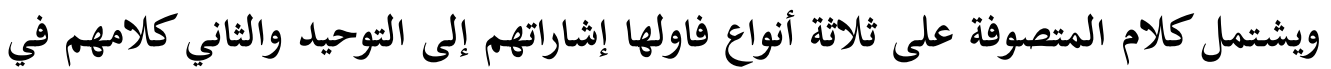

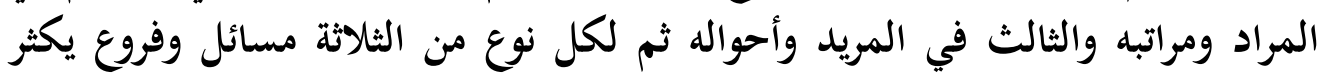

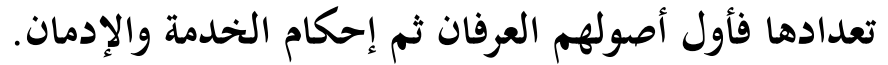

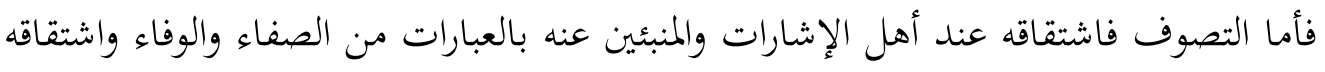

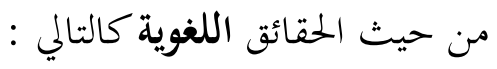
فانه تفعل من أحد أربعة أشياء:

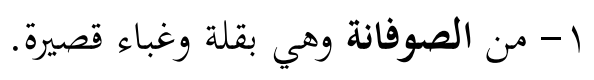

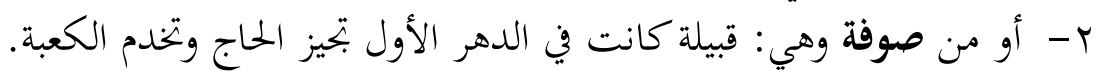
ب- أو من صوفة القفا وهي الشعرات النابتة في متأخره.

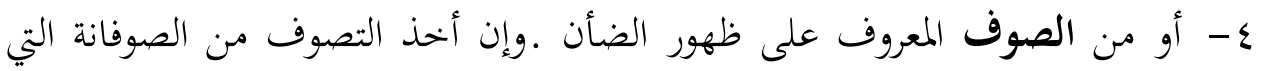

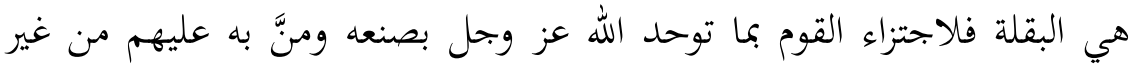

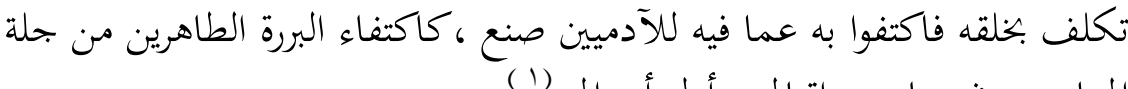
المهاجرين في مباديء إقبالهم وأول أحواهم (1) فئل

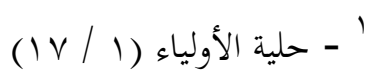




\section{4}

وأما تعريفاته الاصطلاحية عند أهله الأوائل ، فهو ما سأذكره عنهم من خلال أسئلة تعرض عليهم ، أوردها أبو نعيم في ( الحلية).

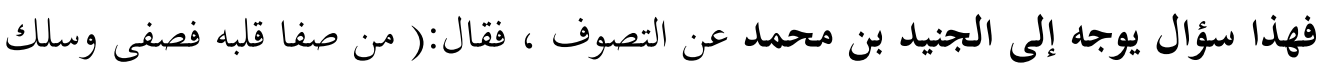

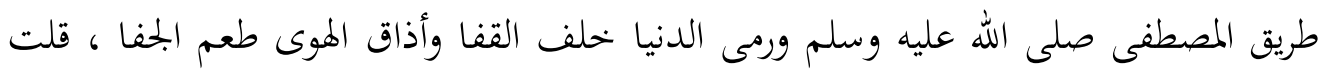

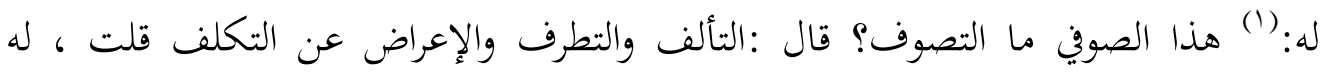

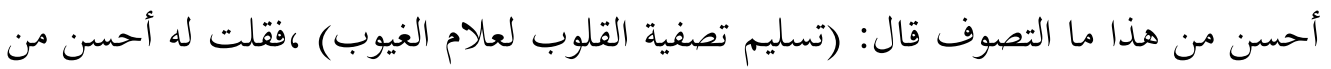

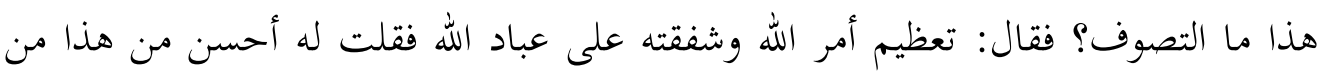

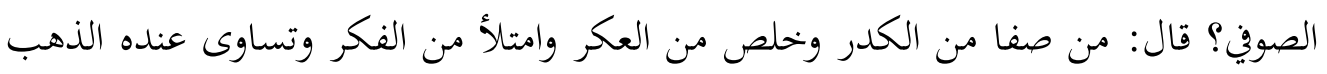

وقال الجنيد بن محمد رممة الله عليه-أيضًا- وسئل عن التصوف فقال: اسم جامع لعشرة

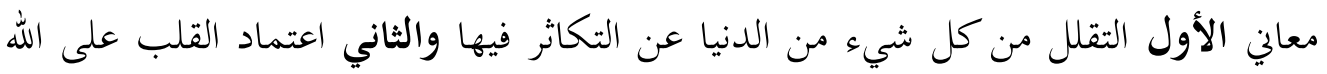

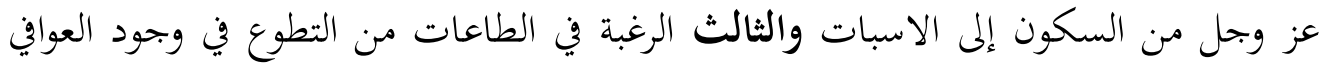

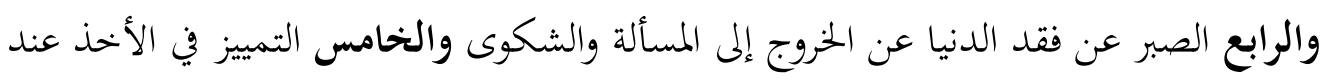

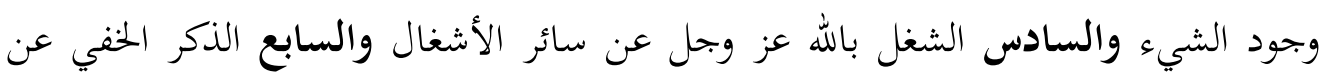

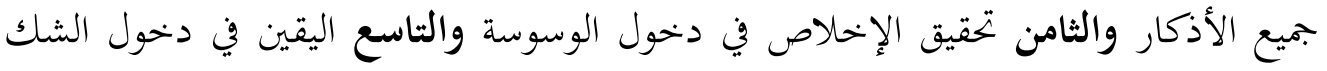

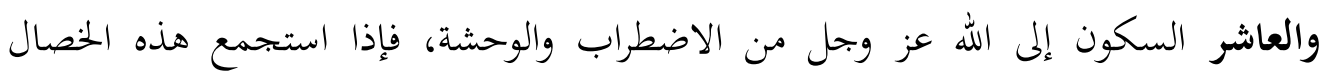
(استحق بها الاسم وإلا فهو كاذب) الستون

وسئل السرى السقطي عن التصوف فقال:( التصوف خلق كريم يخرجه الكريم إلى قوم كرام)

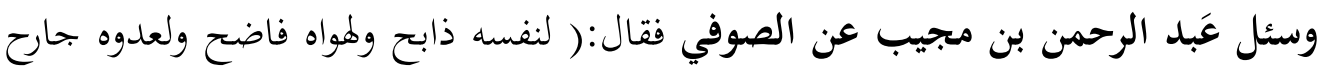

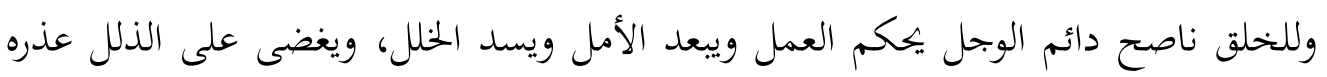

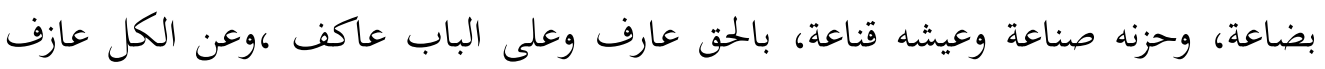

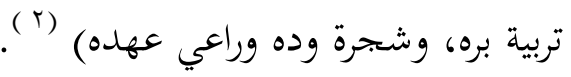

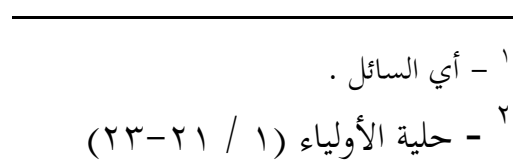


وقال ذو النون- رمة الله عليه- حينما سئل عن الصوفي فقال:( من إذا نطق أبان نطقه عن

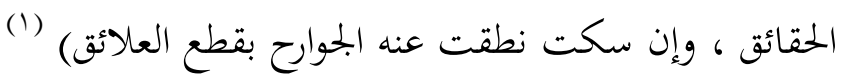
وقد قيل: (إن التصوف تطليق الدنيا بتاتا والإعراض عن منالها ثباتا) (r) '.

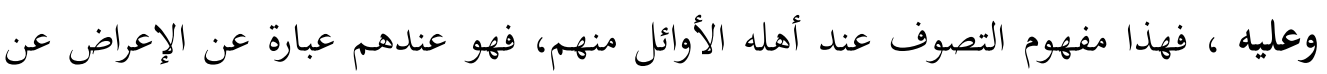

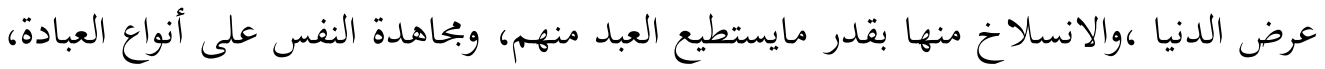

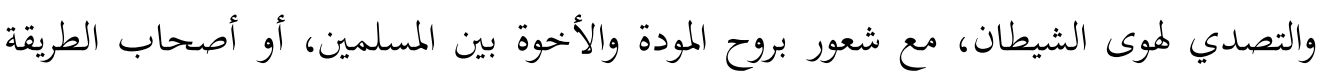

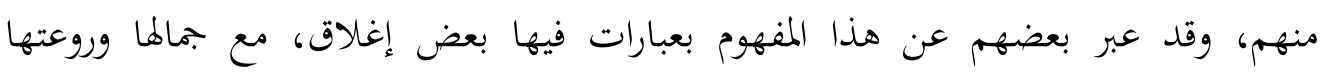

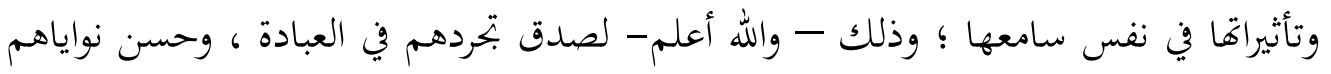

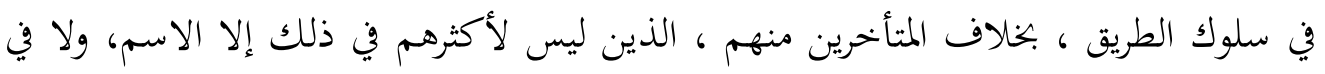
تحليهم بالصوفية إلا الرسم، عقائدهم وأفكارهم منكوسة، وبواطنهم مطموسة، وآراؤهم بتحاه

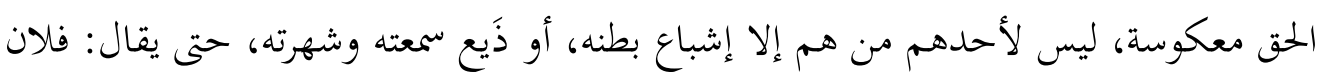
الصويف الزاهد ، وليس له من ذلك حظ ولا نصيب.

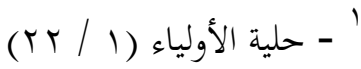

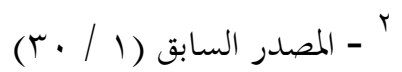


الفصل الثاني : نشأتها الأولى

إن الإسلام دين اليسر ودين الفطرة التي فطر الناس عليها ، أنزله الله على قلب سيد الملى الخلق

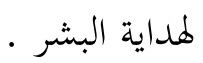

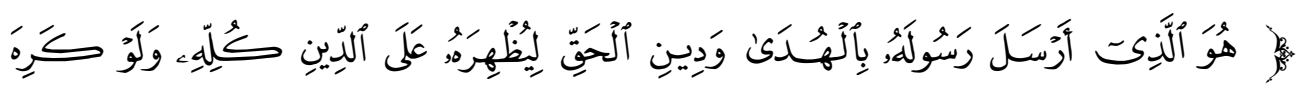

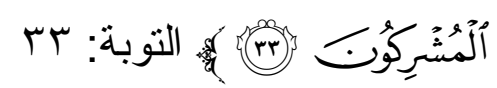
وأمر سبحانه جل وعلا أن يتمسك بك به ، ويقدمه إلى الناس ليعرفوه ويتمسكوا به بدورهم .

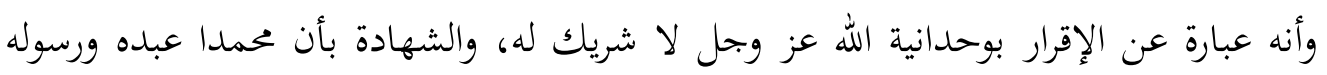

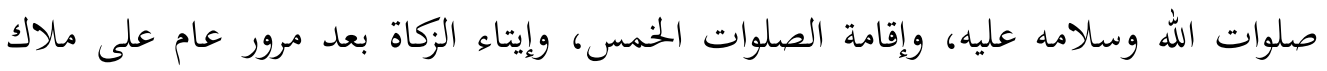

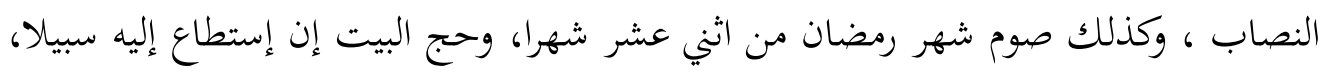

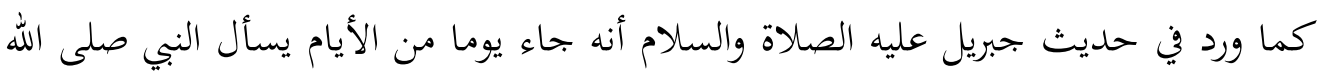

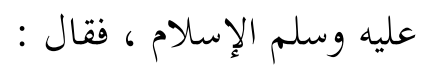
( الإسلام أن تشهد أن لا إله إلا الله وأن محمد رسول الله ، وتقيم الصلاة، وتؤتي الزكاة،

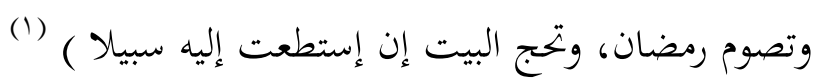

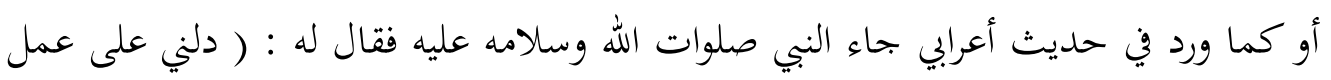
إذا عملته دخلت الجنة). قال : ( تعبد الله ولا تشرك به شيئا ، وتقيم الصلاة المكتوبة ، وتؤتي الزكاة المفروضة ، وتصوم

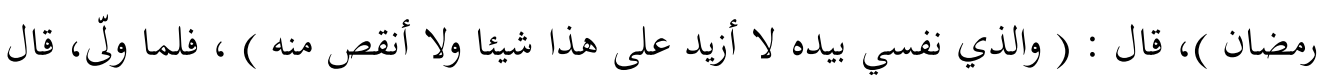
النبي أس

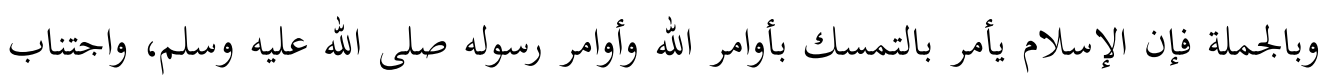
ما فى الله عنه ورسوله صلى الله عليه وسلم ،وقضاء حياة مثل ما قضاها رسول الله، واختيار

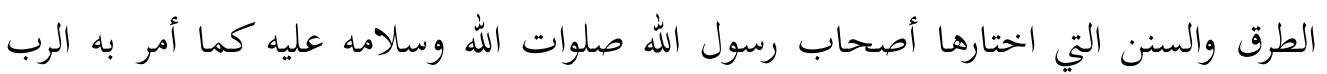
تبارك وتعالى في كلامه المحكم :

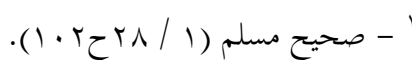

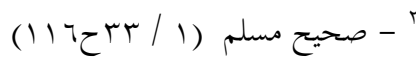




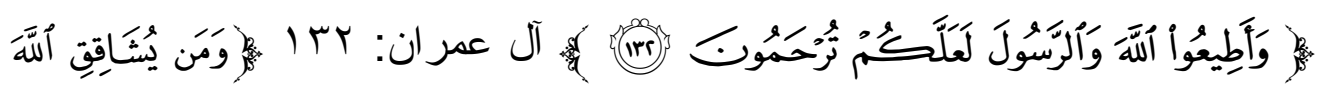

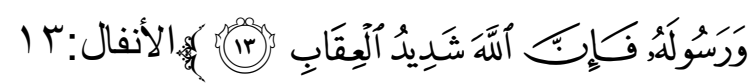

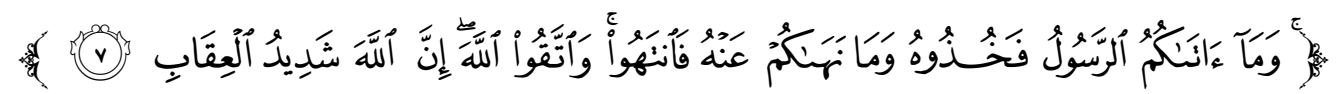

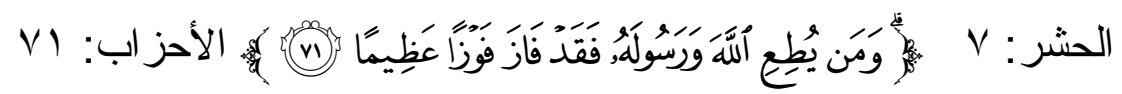

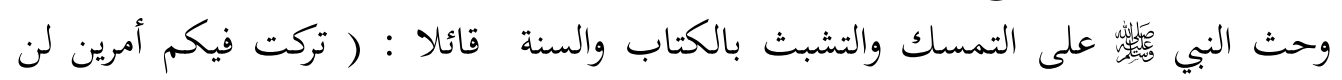
تضلوا ما تمسكتم بكما كتاب الله وسنة رسوله ) (1).

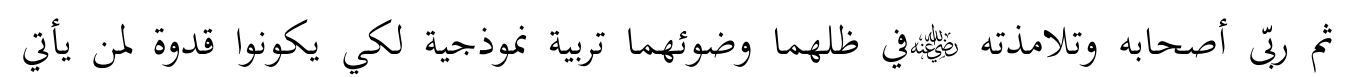

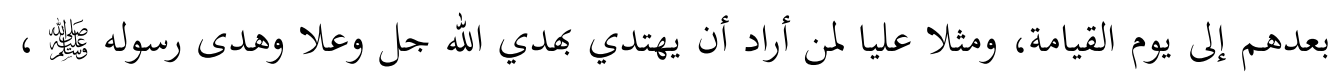

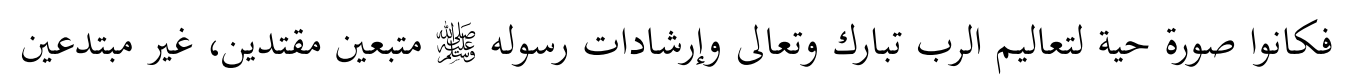

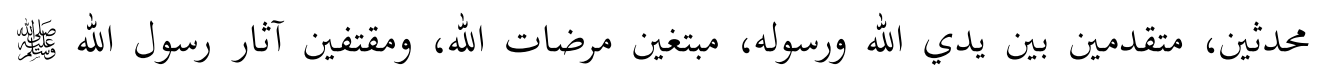

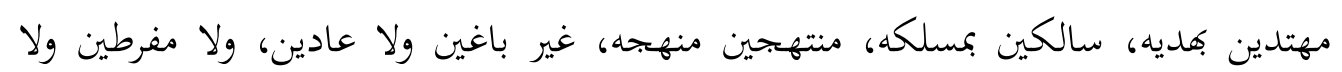

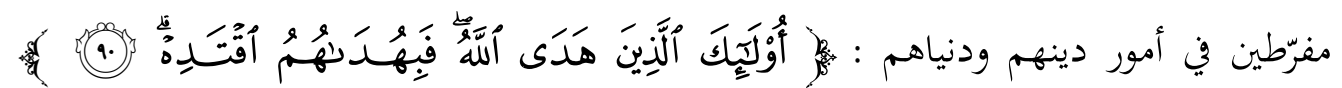
الأنعام: .9 9 وكان خيار هؤلاء كلهم - وكلهم خيار الخلق أجمعين - أصحاب بيعة الرضوان الذين بايعوا

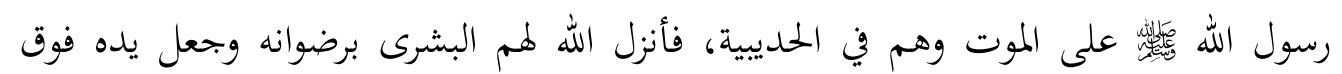

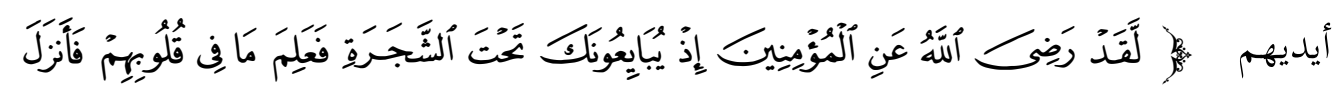

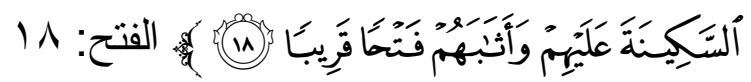

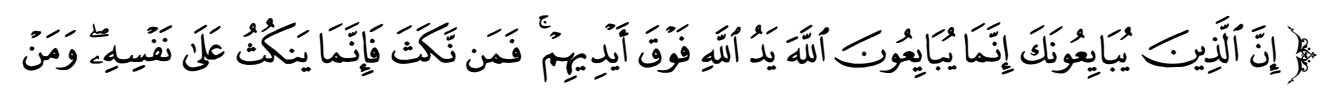

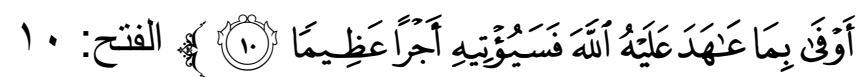

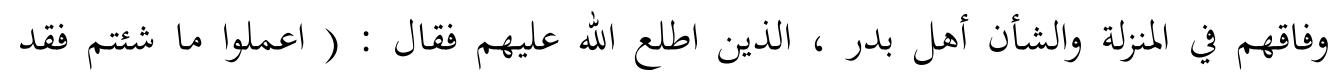

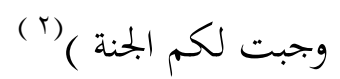
وبمثل ذلك قال الإمام أبو إسحاق الشاطبي في (إعتصامه) (")

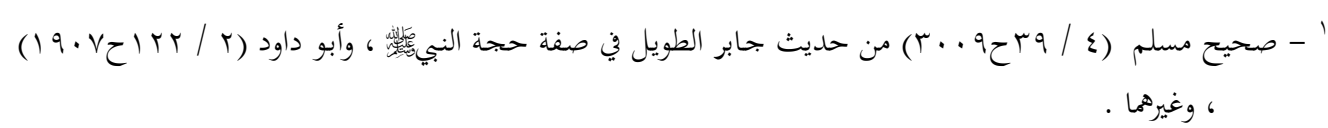

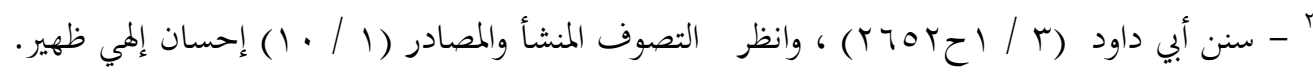

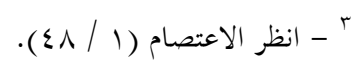


( والثاني : إن الشريعة جاءت كاملة لا تحتمل الزيادة ولا النقصان ، لن الله تعالى قال فيها :

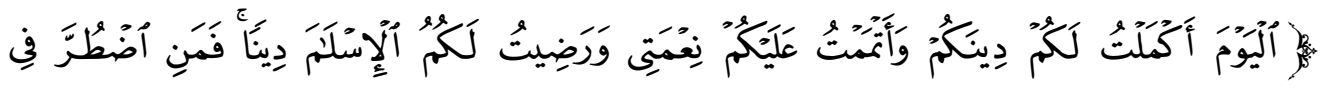

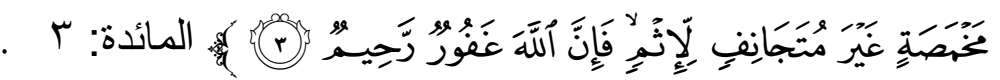

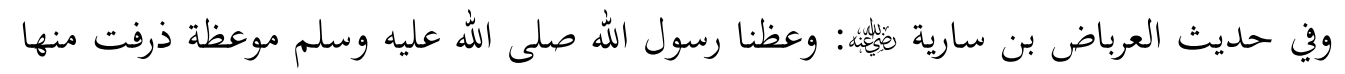

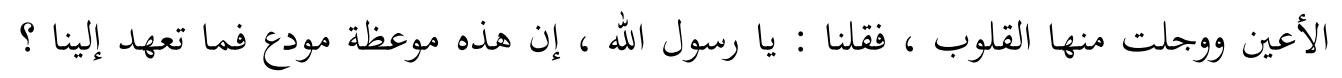

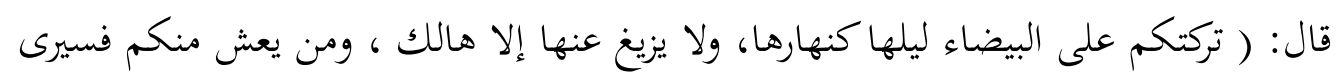

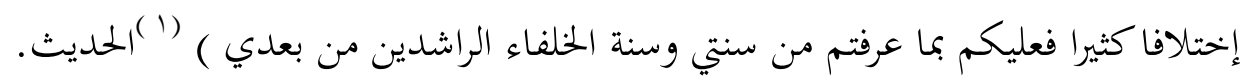

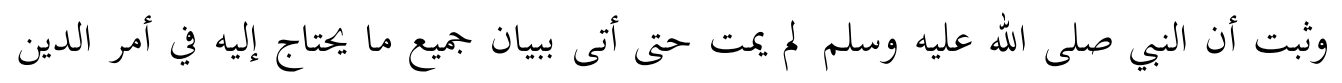
والدنيا وهذا لا خخالف عليه من أهل السنة.

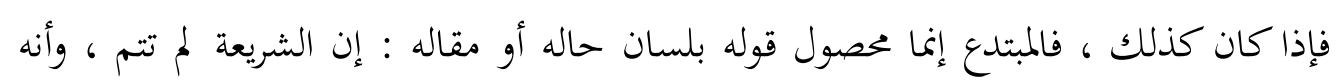

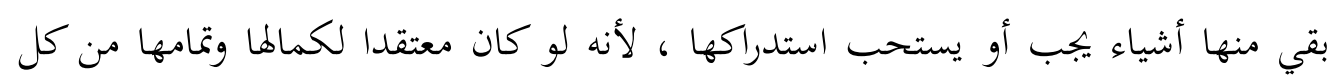

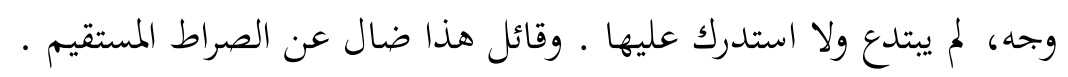

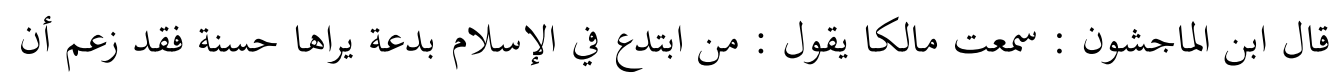

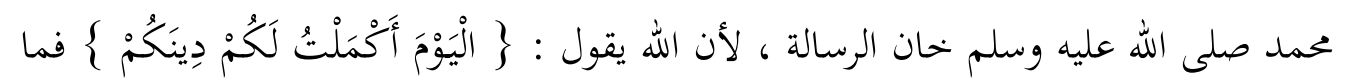
لم يكن يومئذ دينا ، فلا يكون اليوم دينا

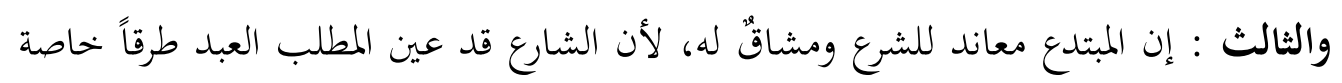

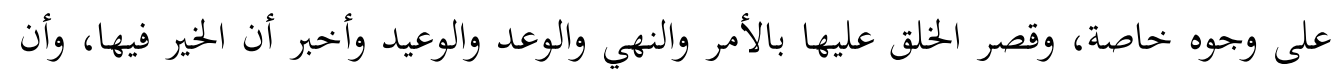

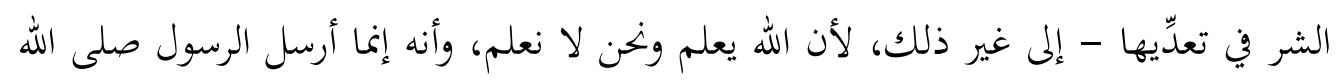

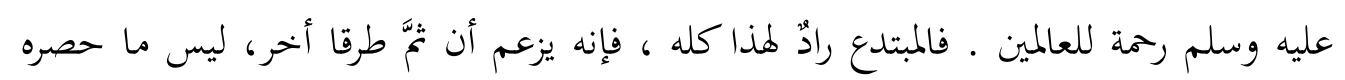

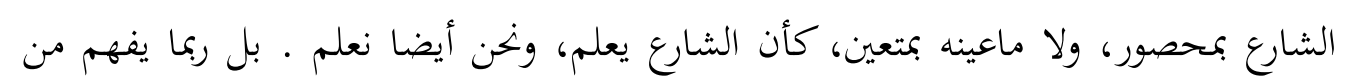

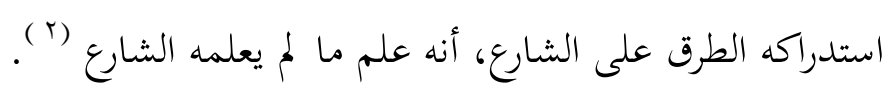

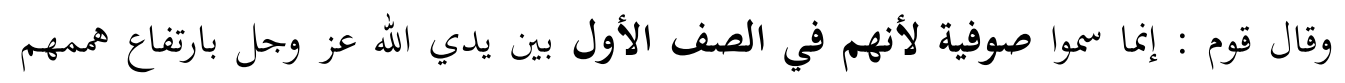
إليه، وإقبالهم عليه ، ووقوفهم بسائرهم بين يديه .

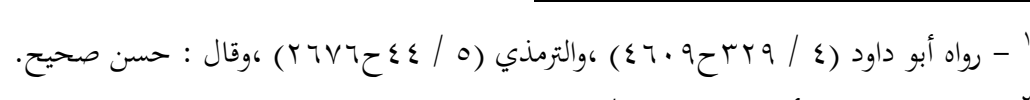

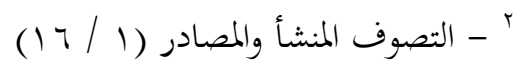


وقال قوم : إنما سموا صوفية لقرب أوصافهم من أوصاف أهل الصفة، الذين كانوا على عهد رسول الله صلى الله عليه وسلم • وقال قوم : إنما سموا صوفية للبسهم الصوف .

وأما من نسبهم إلى الصفة والصوف فإنه عبّر عن ظاهر أحوالهم، وذلك أفم قوم قد تركوا الدنيا ، فخرجوا عن الأوطان ، وهجروا الأخدان، وساحوا في البلاد، وأجاعوا الأكباد، وأعروا الأجساد، لم يأخذوا من الدنيا إلا من الدنيا إلا ما لا يجوز تركه ، من ستر عورة ، وسد جوعة. فلخروجهم عن الأوطان سموا غرباء . ولكثرة أسفارهم سموا سياحين ( '). عن أبي حازم عن أبي هريرة رضي الله عنه قال * (لقد كان أصحاب الصفة سبعين رجلا مالهم أردية)( ) قال الحاكم :(تأملت هذه الأخبار الواردة في أهل الصفة فوجدقمم من أكابر

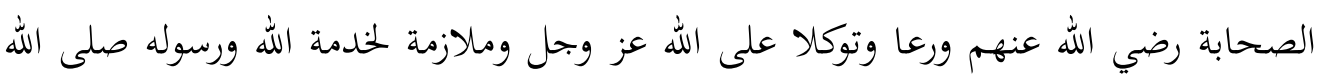
عليه وسلم اختاره الله تعالى لهم ما اختاره لنبيه وجل وترك الدنيا لأهلها، وهم الطائفة المنتمية إليهم الصوفية قرنا بعد قرن، فمن جرى على هلى سنتهم وصبرهم على ترك الدنيا والأنس بالفقر وترك التعرض للسؤال فهم في كل عصر بأهل الصفة مقتدون وعلى خالقهم متوكلون). وبعد هذا وغيره مما يبين كمال الشريعة ، وسمو منزلتها ، وأن الله - تبارك وتعالى - أتم على

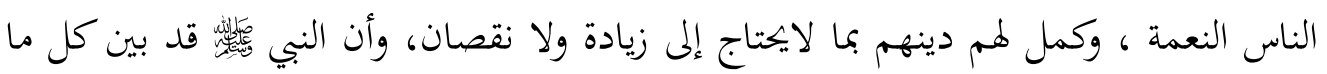
تحتاجه الأمة من أمور دينها ، وقد سار الصحابة -رضي الله عنهم- على المنهج الذي رسمه

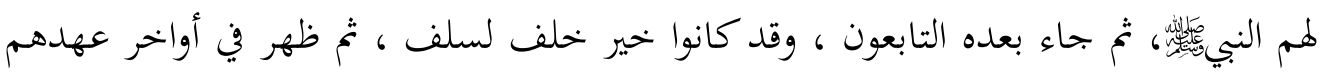
نوع جديد من التأثر الروحي نحو العبادة، والتلفظ بألفاظ وعبارات غامضة إلى حدِّ ما. محا يجد

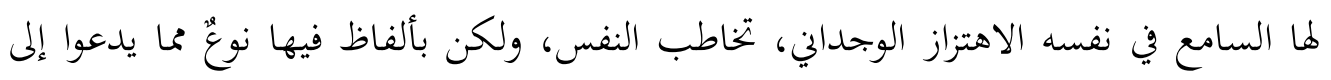
تعلق من وراءهم بها، حتى أولوها تأويلات بعيدة المأخذ غريبة المنبع، وكأن أصحابها ليس لهم هم إلا الترنم بتلك الألفاظ ، والتعبد بمدلولاتها التي شرق بها قائلها وغرب ،فانظر -مثلاً-

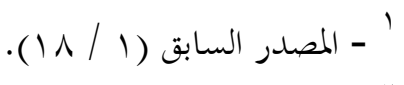

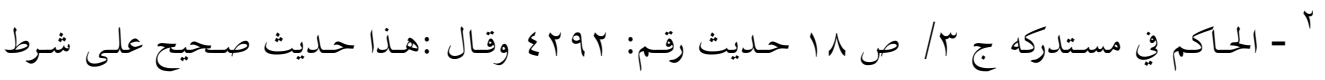

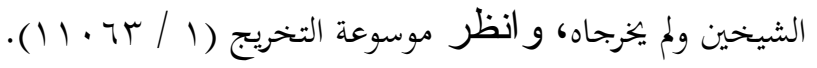




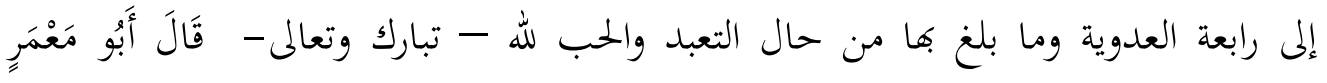

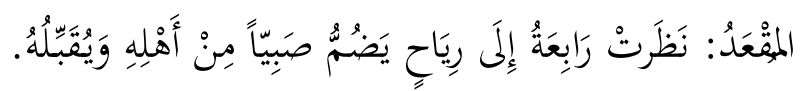

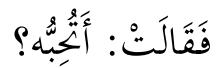

$$
\text { قَالَ: نَعَمْ. }
$$

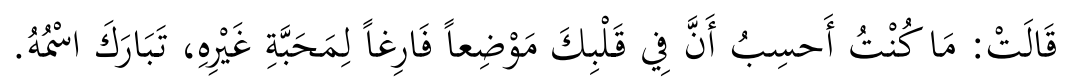

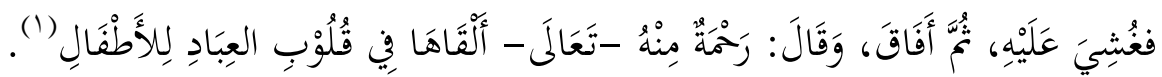

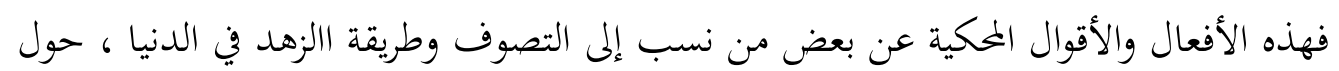

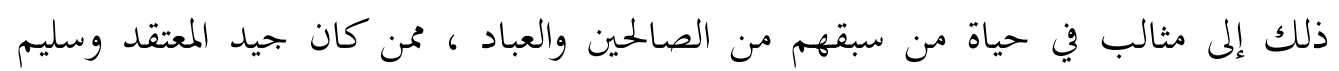

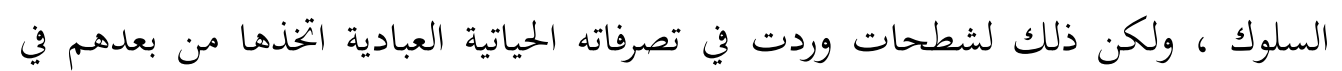

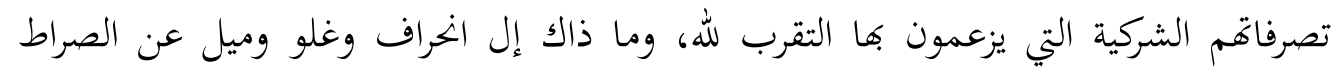
فرابعة العدوية ذُكر عنها من الألفاظ ما مثله يستبعد أن يقوله مثلها، أو لعلها بسبب أو آخر

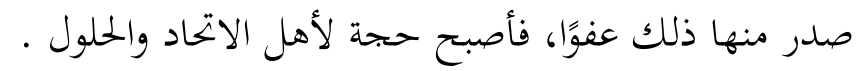

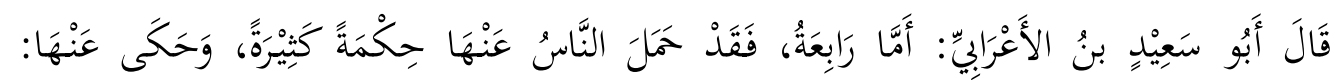

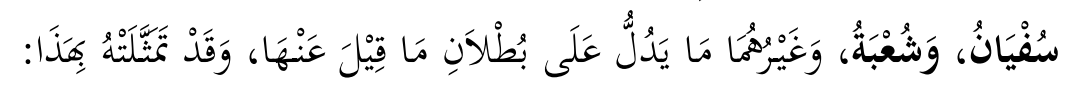

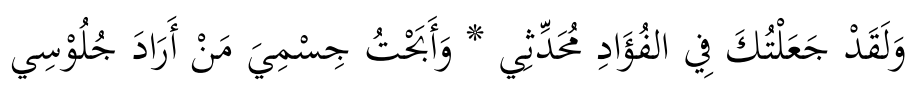

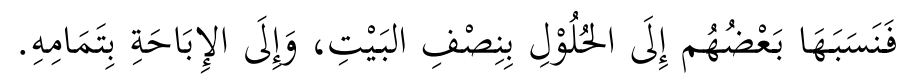

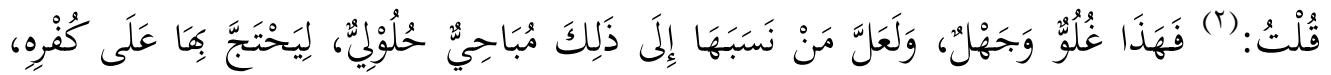

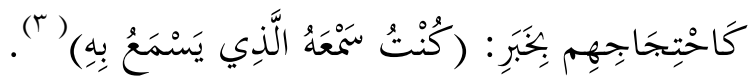

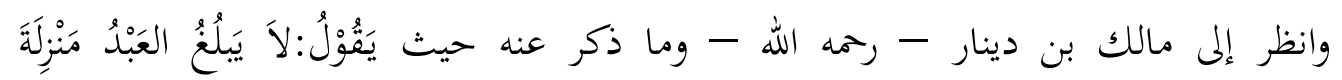

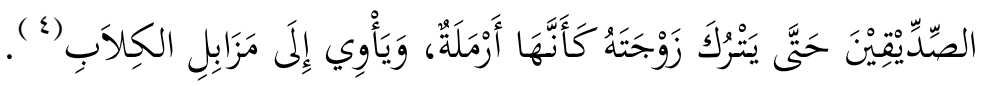
قلت: إن ثبت ذلك عنه، فلا أظظه يريد هجر السنة والحيد عنها، وإنما لعله أراد المبالغة في

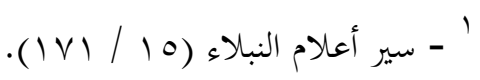

$$
\begin{aligned}
& \text { " - " أي الذهبي. }
\end{aligned}
$$

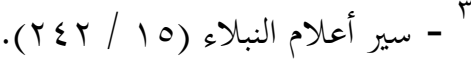

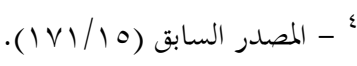




\section{1..}

الزهد والعبادة و والرغبة الصادقة في الإعراض عن الدنيا والإقبال على الآخرة ، وإن أراد مالك

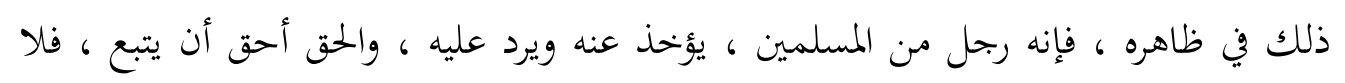

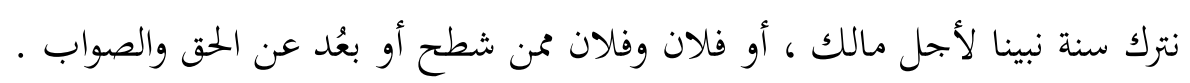

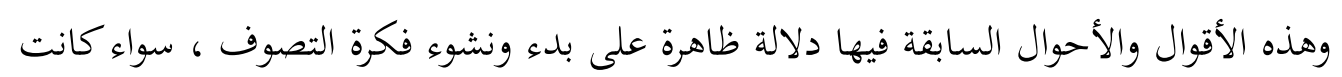

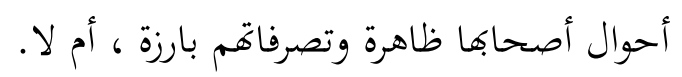

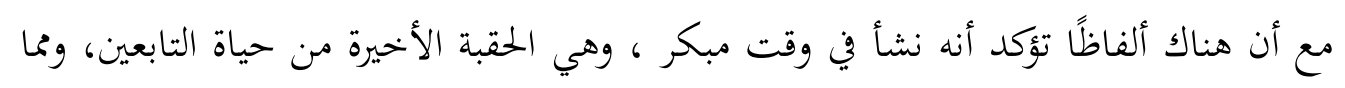

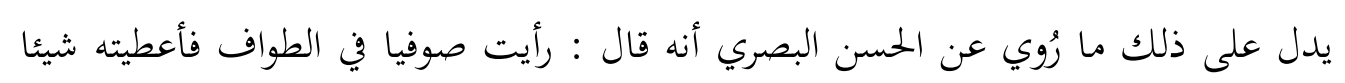

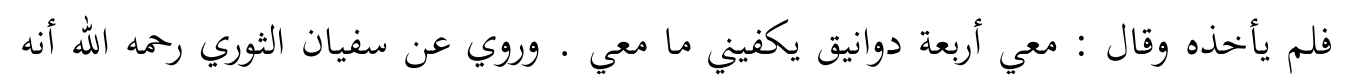

$$
\text { قال : لولا أبو هاشم الصوفي ما عرفت دقيق الرياء (1). }
$$

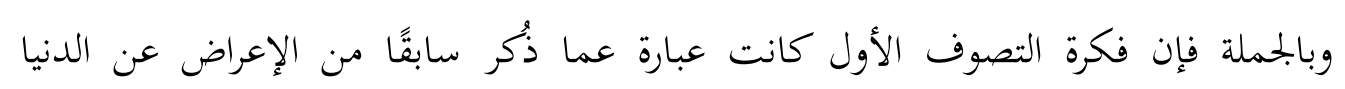

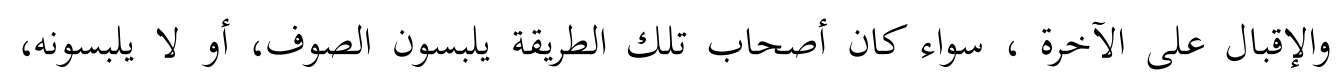

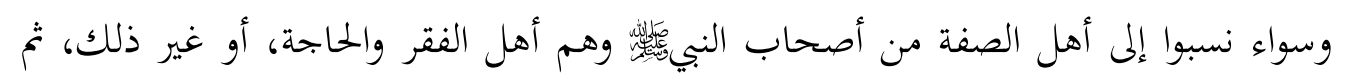

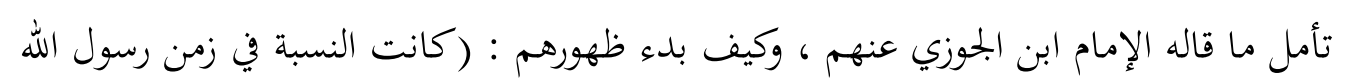

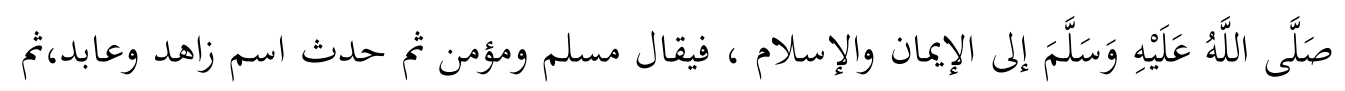

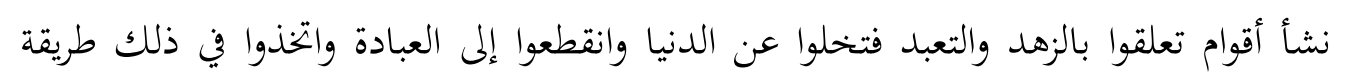

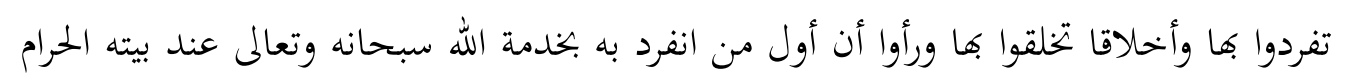

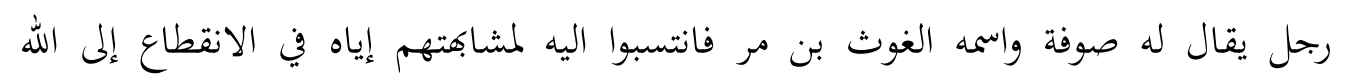
سبحانه وتعالى فسموا بالصوفية..) إلخا (ج).

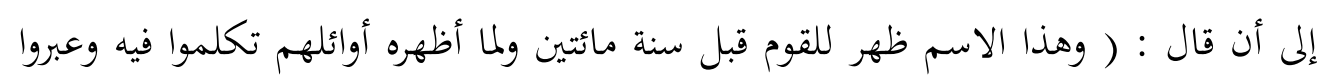

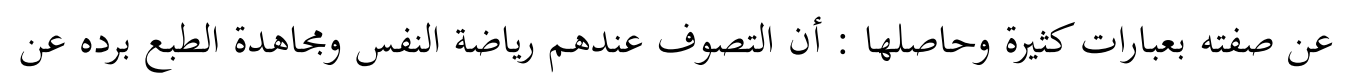

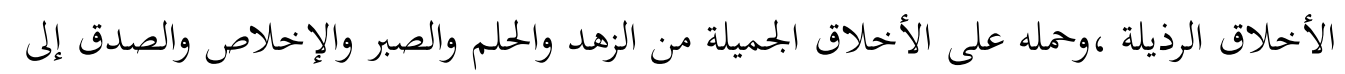

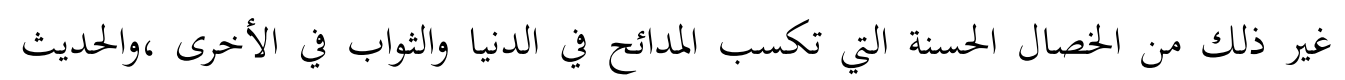

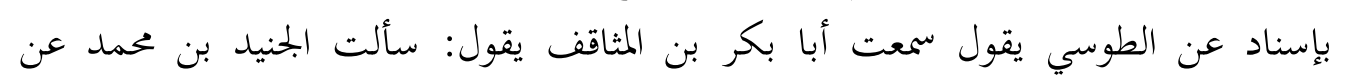

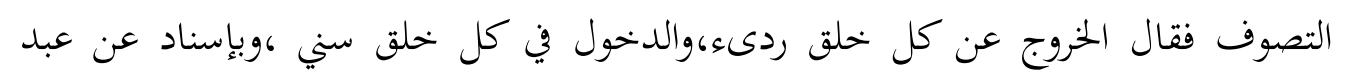

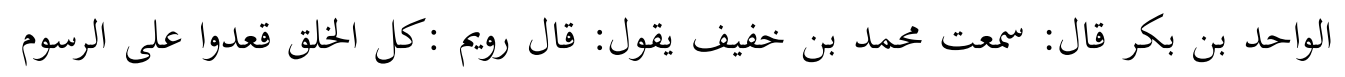

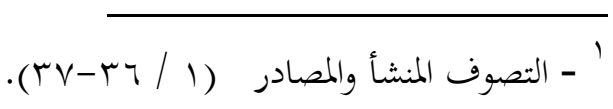

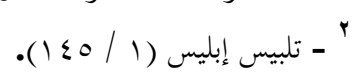




\section{$1 \cdot 1$}

وقعدت هذه الطائفة على الحقائق وطالب الخلق كلهم أنفسهم بظواهر الشرع ،وهم طالبوا أنفسهم بحقيقة الورع ومداومة الصدق.

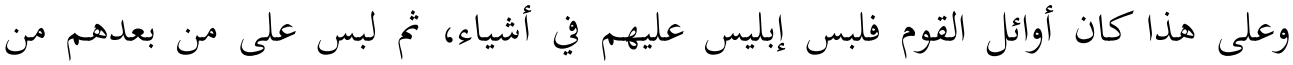

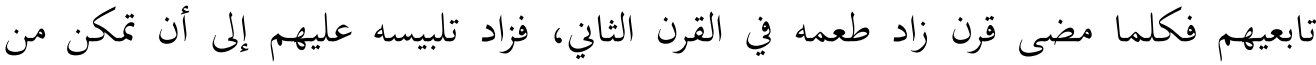

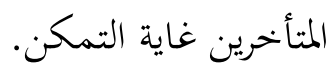
وكان أصل تلبيسه عليهم أنه صدهم عن العلم وأراهم أن المقصود العمل، فلما أطفأ مصباح

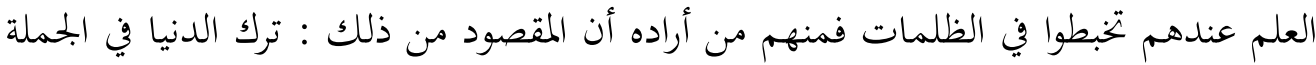

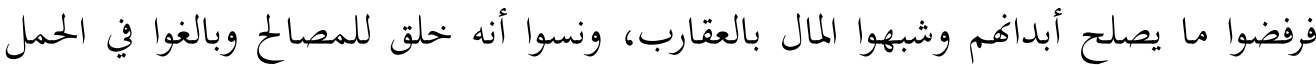

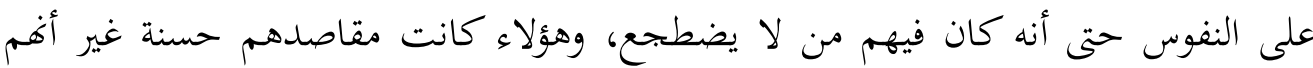

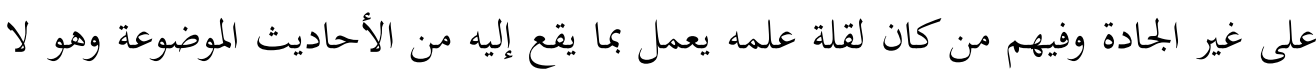

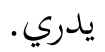
ثم جاء أقوام فتكلموا لمم في الجموع والفقر والوساوس والخطرات وصنفوا في ذلك مثل الحارث

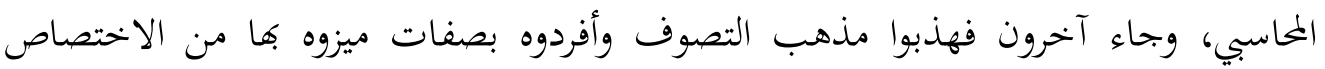

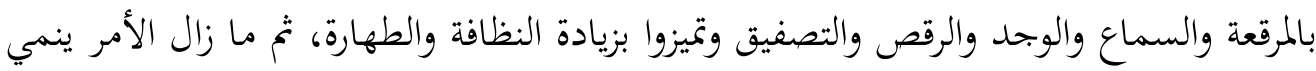

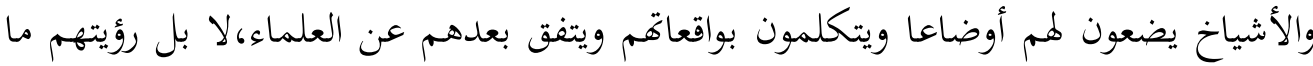

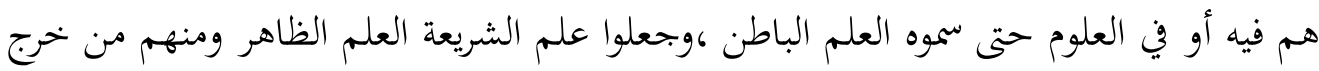

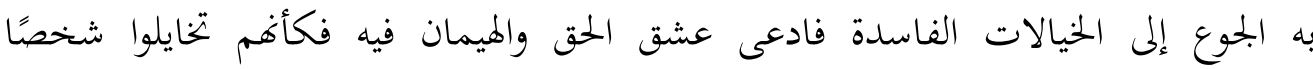

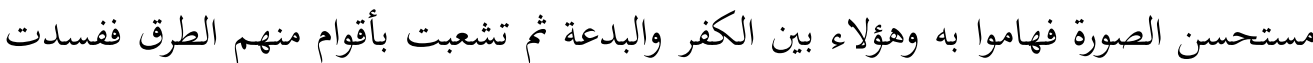

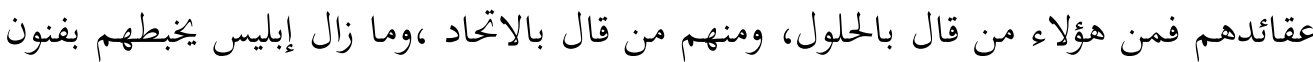

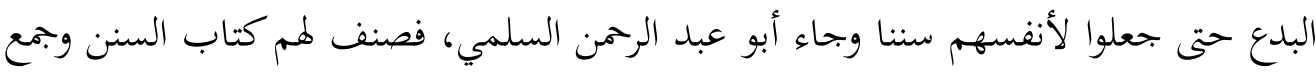

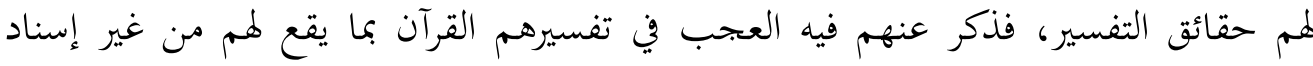

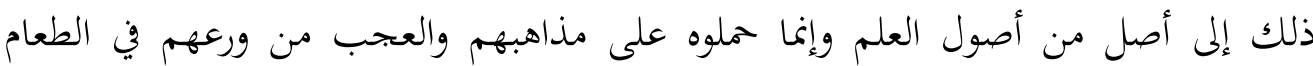

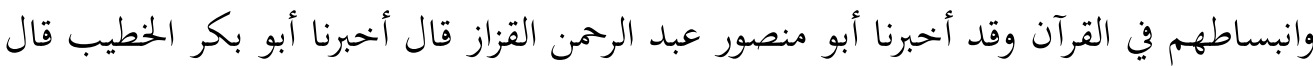

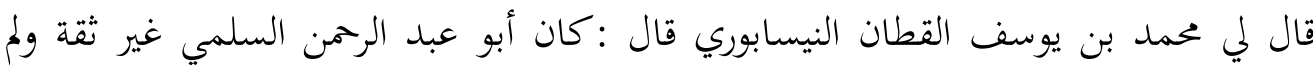

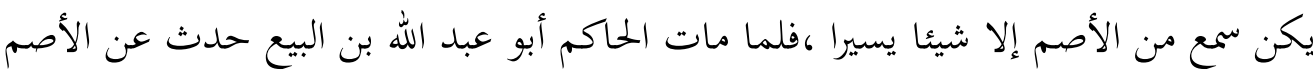

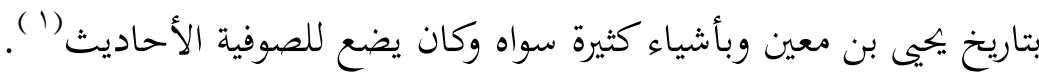


الفصل الثالث : معتقدات الفكر الصوفي فيما يتعلق بصفات الله تعالى:

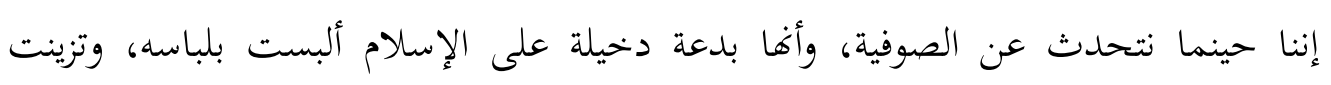
بدثاره وشعاره، = لابد أن نذكر أعظم جوانب الضلال الظاهرة في كياها، وتحت سربالها

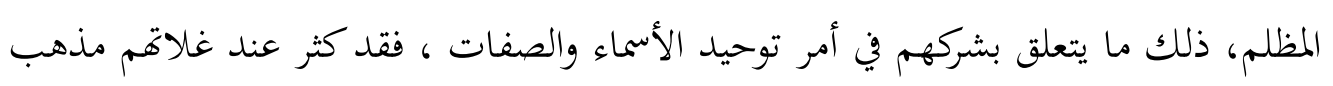
التشبيه ؛ ولذذا يزعمون أغهم يصافحون الله، ويعانقونه، ويسامرونه، ويجالسونه -تعالى الله عن الهن ذلك علو كبيرا-

مع أن القصد هو العدل في معرفة الحق بجاه هذا النوع من التوحيد، وهو سلوك الطريقة السليمة بين الأمرين. بمعنى: أن يتوسط الإنسان بين التشبيه، وبين التعطيل. يثبت، وينزه.

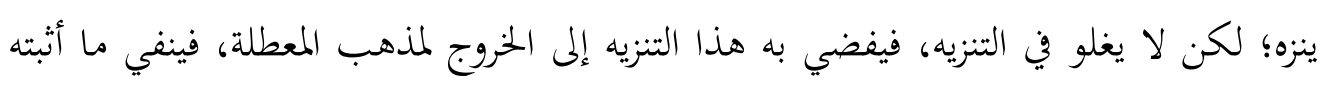
الله. ويثبت؛ لكن لا يغلو في الإثبات، فيفضي به هذا الأمر إلى تشبيه الخالق بالمخلوق، كما هي الحال عند المشبهة. والمطلوب من العبد اثبات الصفات بلا تكييف ولا تمثيل ولا تشبيه (1). وقال أبو نعيم الأصبهاني -صاحب "الحلية"- في عقيدة له، في أولها: طريقتنا طريقة المتبعين للكتاب والسنة وإجماع الأمة. ومما يجدر أن نؤكده مرارًا : أن العلماء المتقدمين ممن ظهر منهم نوع تصوف ، أو برزت منهم

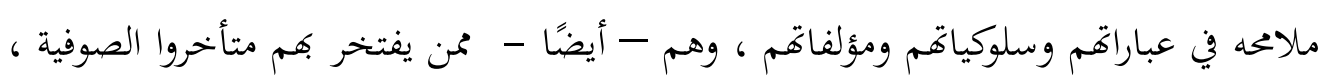

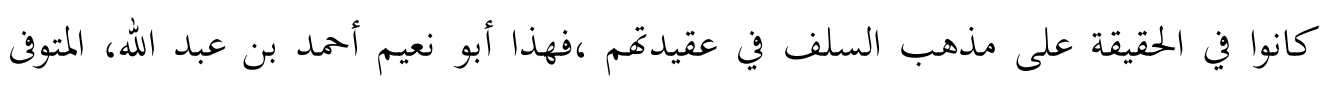

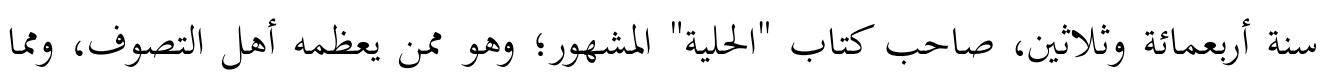

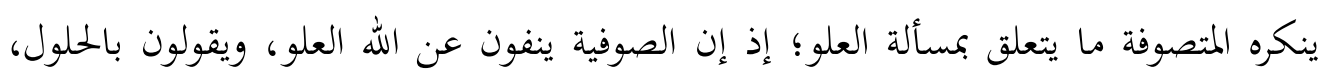
وأن الله مختلط حال ممتزج بالخلق -تعالى الله عن ذلك علو كبيرا-. ومما يعتقده أبو نعيم وأهل الحق من الصوفية الأُول: أنّ الأحاديث التي ثبتت عن النبي - صلى الله عليه وسلم - في العرش واستواء الله يقولون بها، ويثبتوها من غير تكييف ولا تمثيل ولا 


\section{$1 \cdot r$}

تشبيه، وأن الله بائن من خلقه، والخلق بائنون منه، لا يحل فيهم، ولا يمتزج بهم، وهو مستو

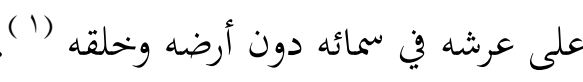
ويقول أبو نعيم: في عقيدة له، في أولها:( طريقتنا طريقة المتبعين للكتاب والسنة وإجماع الأمة. وهذا هو منهج السلف الصالح. أغم يلتزمون الكتاب والسنة على وفق مفهوم سلف الأئمة).

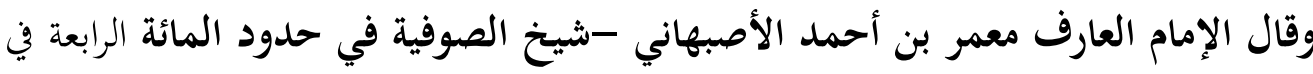

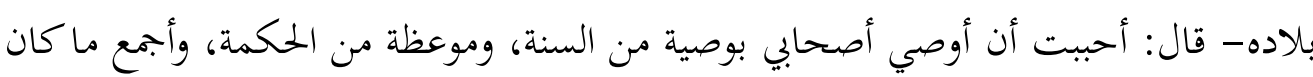

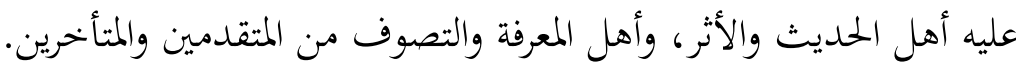

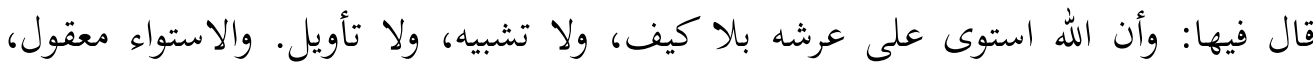
والكيف فيه بحهول. وأنه - عز وجل - بائن من خلقه، والخلق منه بائنون، بلا حلول ولا ممازجة، ولا اختلاط ولا

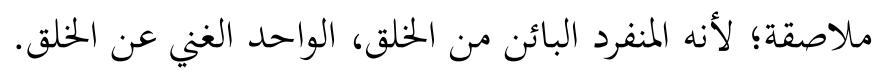

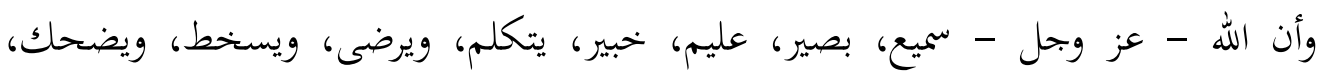

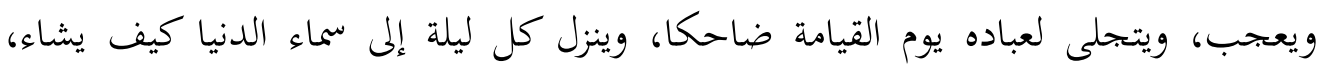

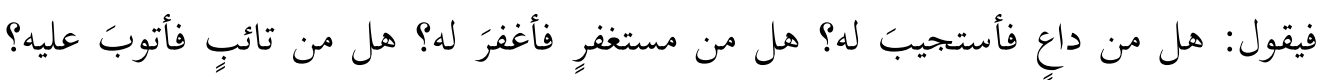

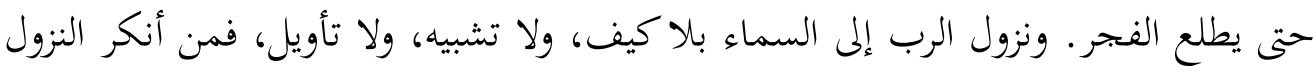
أو تأول فهو مبتدع ضال. وسائر الصفوة من العارفين على هذا.

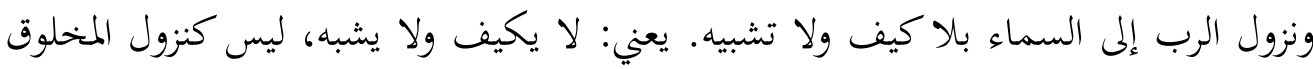

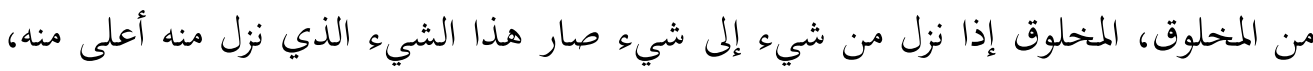

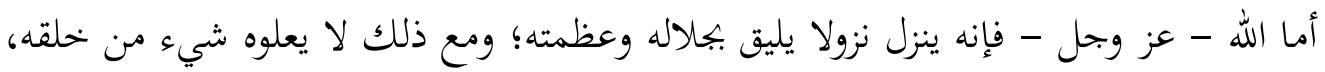

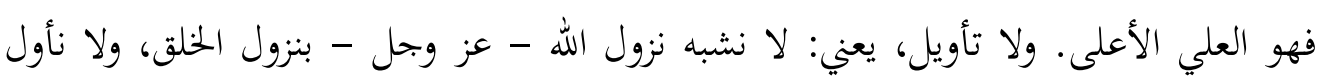

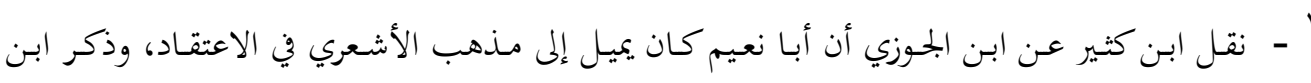

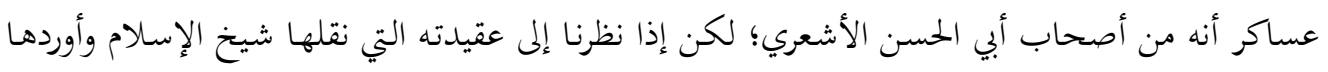

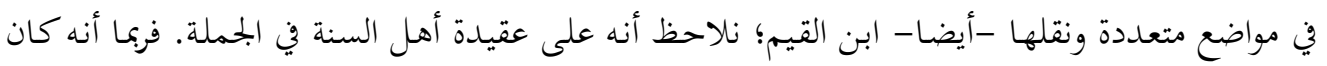

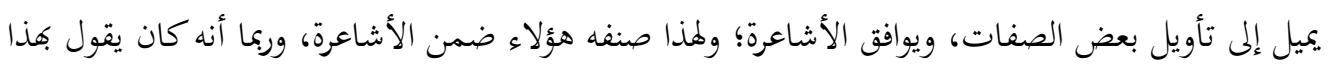

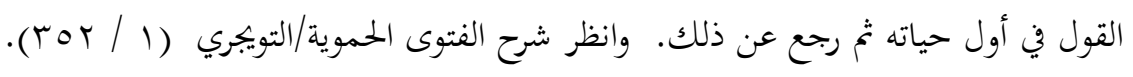




\section{2}

نزول الله - عز وجل - كما أول ذلك المعطلة، فمن أنكر النزول، أو تأول فهو مبتدع ضال،

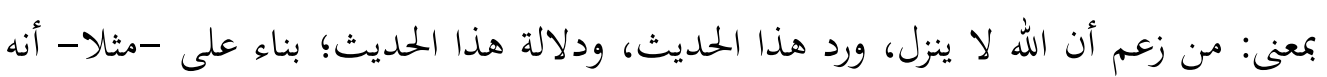

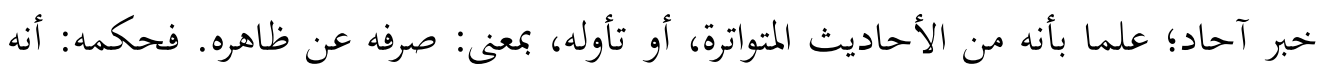

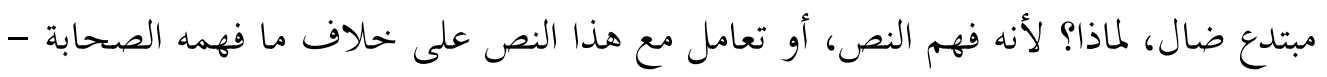

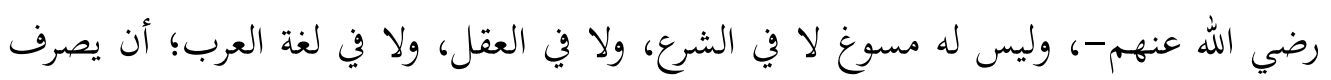
هذا النص عن ظاهره (1).

ومن خلال هذه النصوص يتبين تمامًا عقيدة المعتدلين ممن ينتسب إلى الصوفية من العلماء

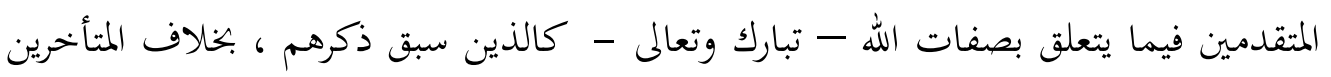

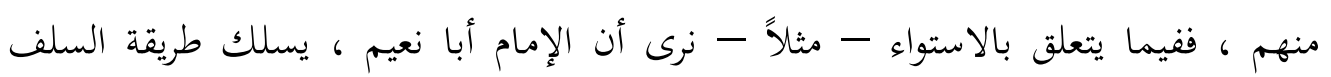

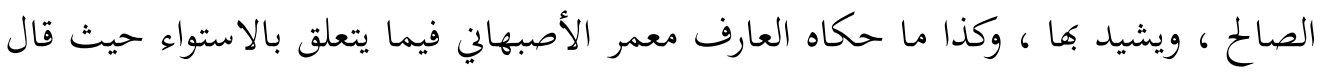

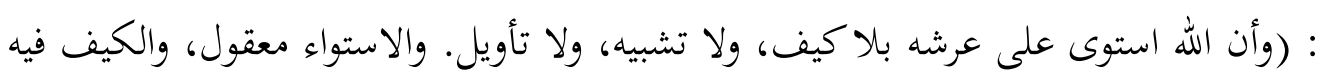

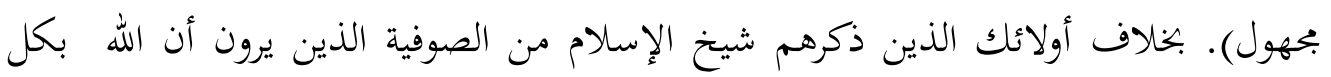
مكان. (r) وهذا القسم من الصوفية حينما يتحدثون بهذا المفهوم السابق للاستواء يعترضهم مفهوم المعية

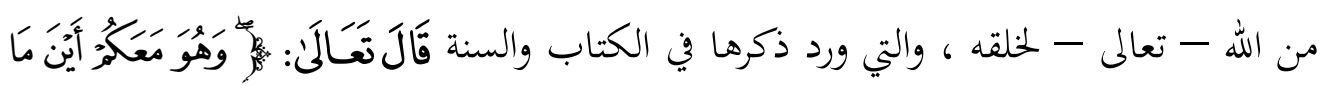

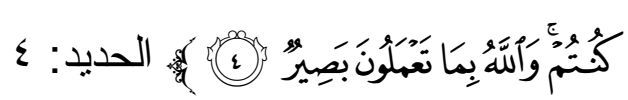

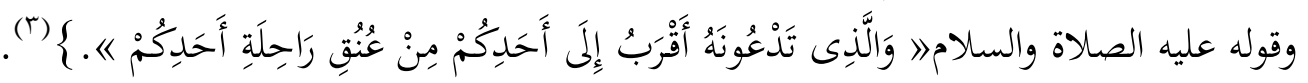

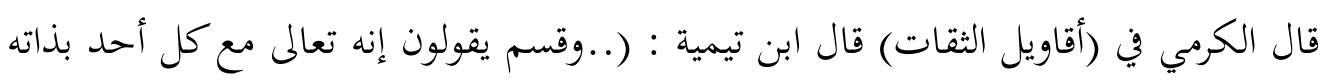

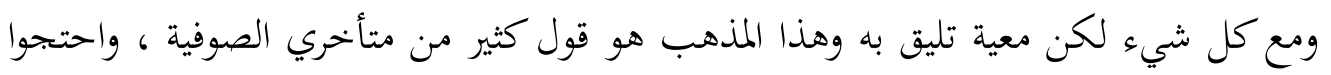

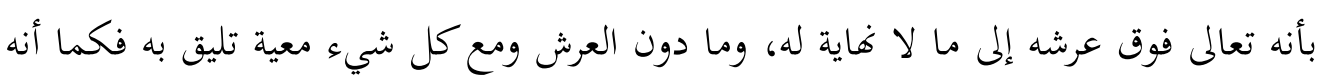
ليس كمثله شيء في ذاته ليس كمثله شيء في صفاته فليس معيته وقربه كمعية أحد منا وقربه .

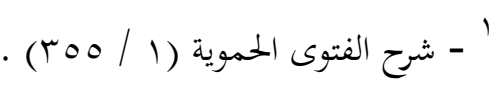

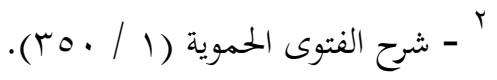

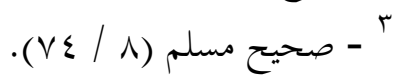




\section{$1 \cdot 0$}

قالوا : فلسنا معطلين لأن تعظيمنا أبلغ من تعظيمهم والتعطيل إنما يكون مع من خلا توحيده

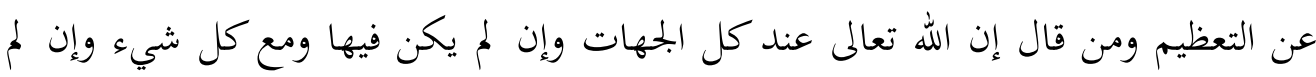

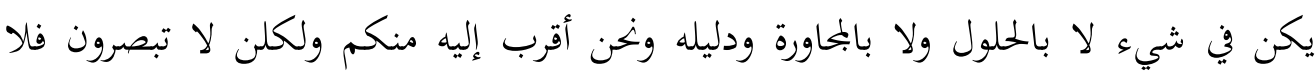

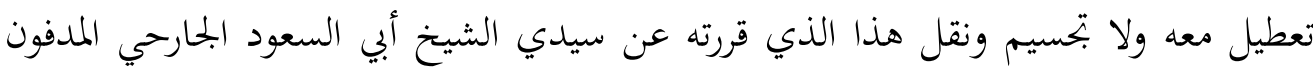

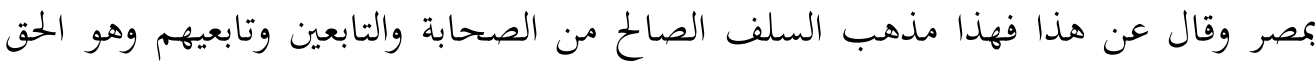
الذي اختاره الصوفية الكرام وفقهاء الإسلام انتهى.

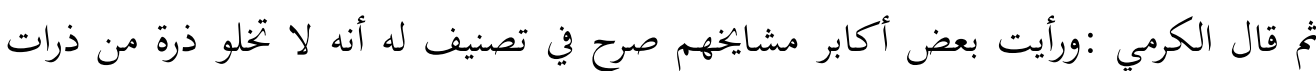

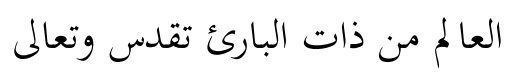

قلت : وهذا شيء ينفر منه الطبع والشرع ولكن لعل تقريبه للعقل أن البارئ سبحانه كان

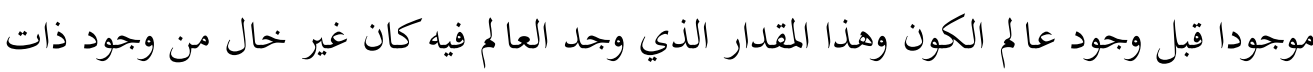

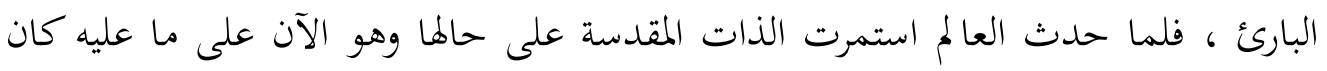

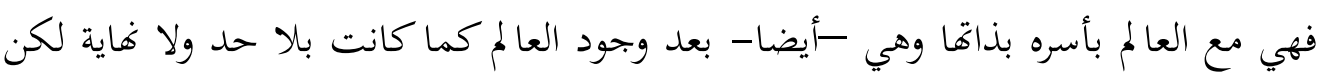

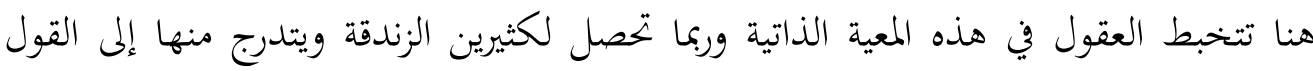
بالوحدة المطلقة) (1)

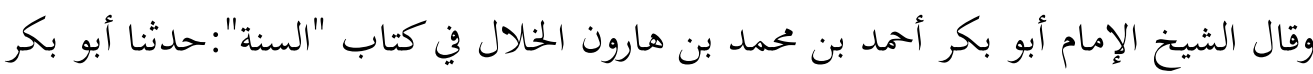
الأثرم، حدثنا إبراهيم بن الحارث -يعني العبادي- حدثنا الليث بن يهيى، قال: سمعت إبراهيم

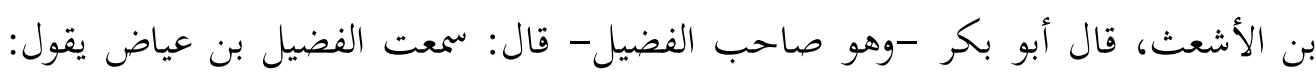

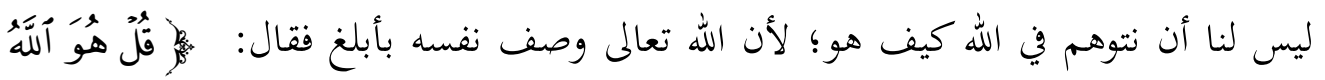

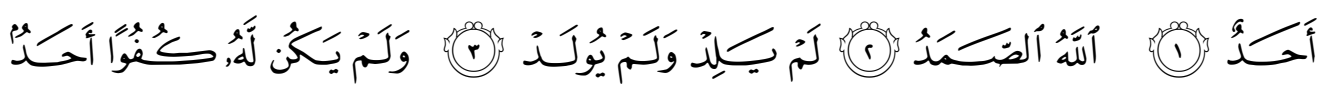
فلا صفةَ أبلغُ مما وصف به نفسه. 


\section{$1 \cdot 7$}

وكل هذا: النزول، والضحك، وهذه المباهاة، وهذا الإطلاع، كما يشاء أن ينزل، وكما يشاء أن

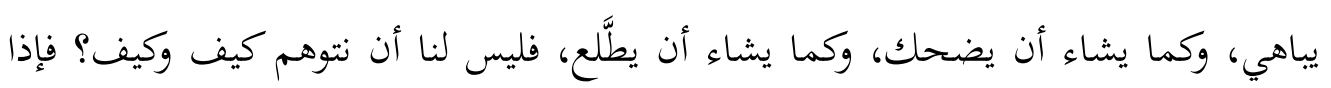

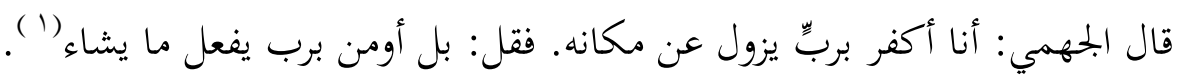

\section{ومن معتقداتهم الباطلة ادعاء علم الغيب:}

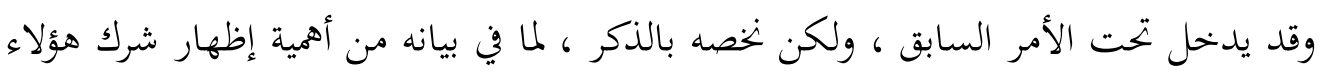

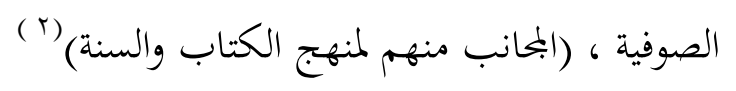

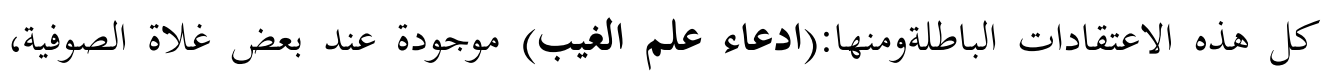

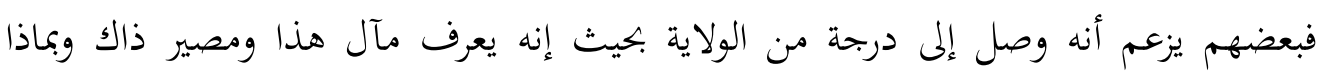

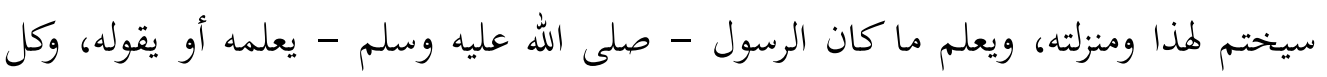
هذا لا شك أنه باطل وكفر؛ لأن فيه ادعاء لعلم الغيب، وعلم الغيب من من الأمور التي استأثر

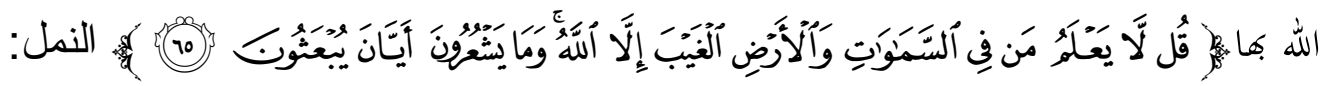
10

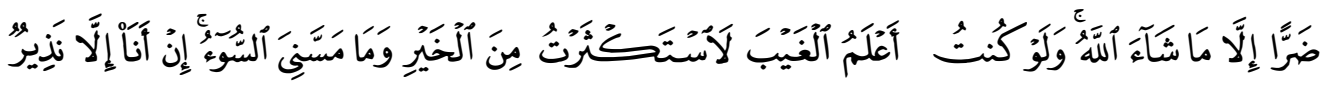

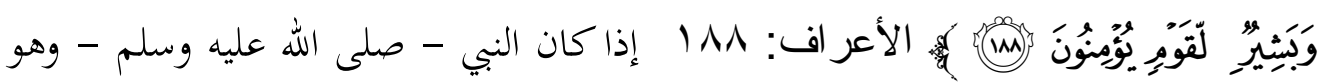

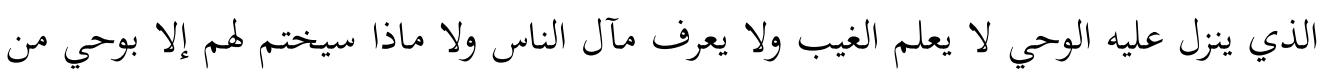

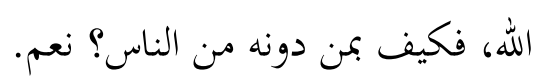
الفراسة ليست من ادعاء علم الغيب. فئ من دونه

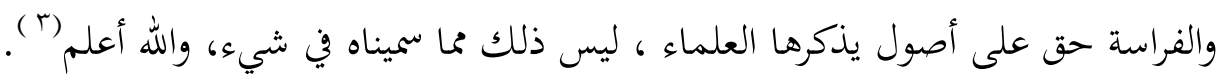

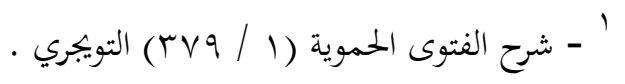

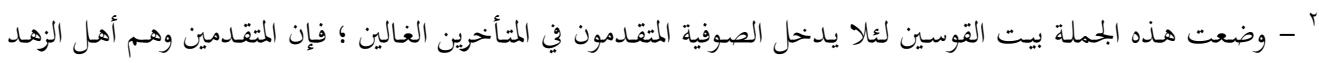

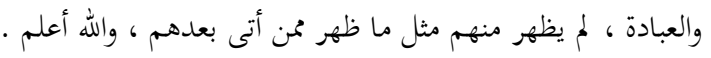

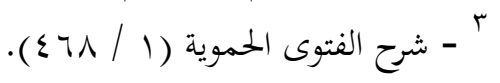




\section{V \\ ومن معتقداتهم: سقوط التكاليف عند وصول العبد إلى منزلة معينة}

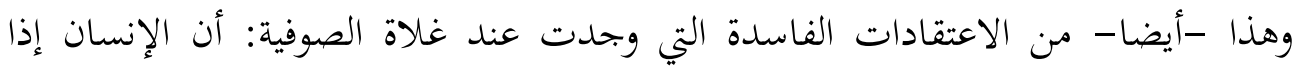
وصل إلى درجة من العلم واليقين سقطت عنه -كما أسلفت- سقطت عنه التكاليف، وأنه

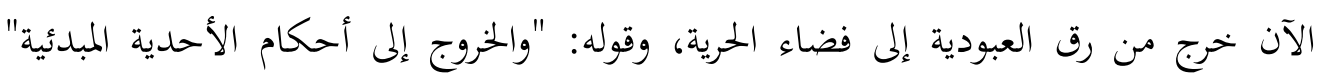

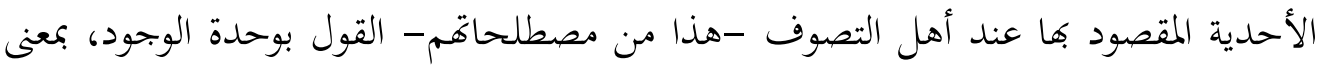
أن هذه الفوارق وهذه القواسم وهذه الاختلافات التي أمام عينيه تنتهي وتصبح شيئا واحدا، التها،

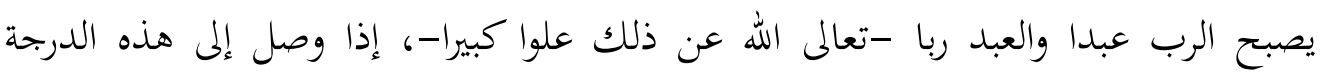
خلاص انتهت التكاليف ولم يعد مكلفا. ولهذا قال الشيخ: هذا كفر لا محالة، وتلاحظون أن بعض الطوائف والفالف الفرق التي ظهرت متأخرا

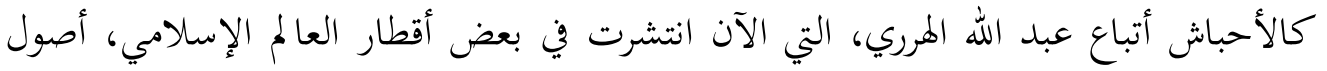

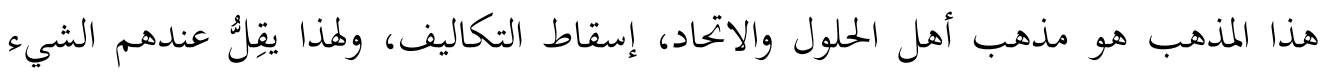
المرم، الأصل عندهم الإباحة، فأصول هذا المذهب مأخوذ من مذهب أملاط أهل الحلول والاتحاد، نعم. كفر من قال بسقوط التكاليف والعبودية عن العبد، فهو كافر لا محالة، إلا من اعتراه علة أو

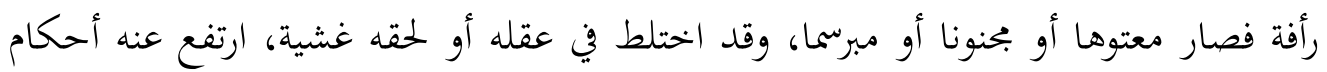

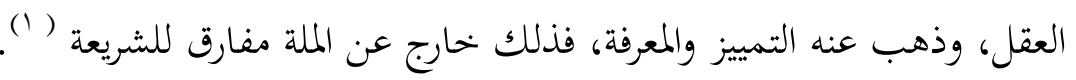




$$
\begin{aligned}
& 1 \cdot 1 \\
& \text { الفصل الرابع : الفرق بين التصوف العملي والتصوف النظري . }
\end{aligned}
$$

لقد افتروا أن التصوف نوعان: نظري أو إشراقي، والغاية منه معرفة الله "بالأذواق" واكتناه أسرار ربوبيته بالمواجيد، فكانت نتيجته أن دان مؤتفكوه بالوحدة التامة بين الخلق والحنالق .

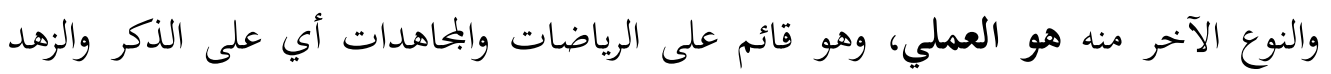
والعبادة. ومحاولة التفرقة بينهما، كالتفرقة بين الخبث وريحه المنتن، فالنظري من التصوف وليد العملي؛ لأن النظرية وليدة التطبيق . ومنذ القرن الثاني وما بعده وحين بدأ المسلمون بنقل كتب الشعوب الأخرى واتسعت دائرة العلوم ، ترجم مقدار من آثار البوذية والهندية مما يدخل في باب التصوف العملي أي : الزهد

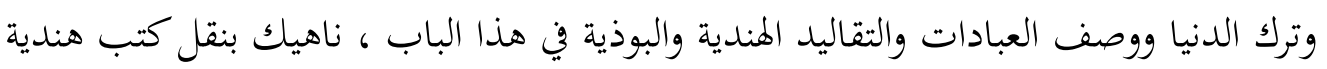
وبوذية في القرن الثاني للهجرة والصالت التجارية والاقتصادية القائمة بين المسلمين والهنود في أوائل الخلافة العباسية وقد انتشرت طائفة من تاركي الدنيا والسائحين من الهنود والمانويين في العراق وسائر البلاد الإسلامية الأخرى وكما كانوا يتحدثون في القرن الأول عن الرهبان

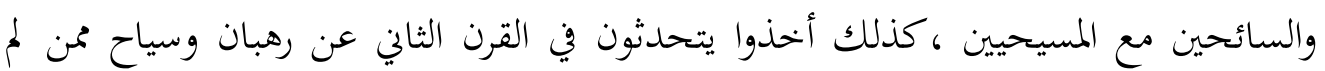
يكونوا مسلمين ولا نصارى، وهم الذين سماهم الجاحظ ( رهبان الزنادقة ) واعتبرهم من زهاد

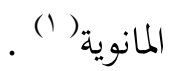
قال الجاحظ : ( إن هؤلاء سياح والسياحة بالنسبة لهم في حكم التوقف واعتزال الساطرة في الصوامع والأديرة ، وتلك الجماعة يسافرون دائما اثنين اثنين ويسيحون بحيث إذا بأئ رأى الإنسان

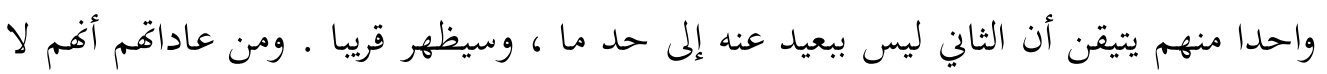
ينامون ليلتين في مكان واحد ، ولهؤلاء السياح خصال أربع : القدس والطهر والصدق والمسكنة

إن التصوف العملي عند الصوفية قائم على الزهد والعبادة، ولكن زهد الصوفية غير التقوى المقررة في الإسلام، والعبادة في الصوفية غيرها في الإسلام. وأي عبادة عند الصوفية؟ أهي تلك الركعات، أو السجدات التي لا يقر فيها قلب، ولا جسد، ولا تسلم فيها لله خاطرة واحدة، ولا يخشع شعور، ولا يضرع دعاء؟ فإنما هي لأصنام القبور سجود وتسابيح،

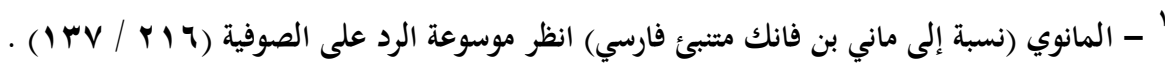

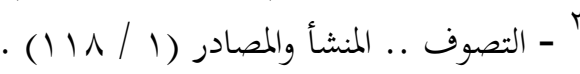




\section{$1 \cdot 9$}

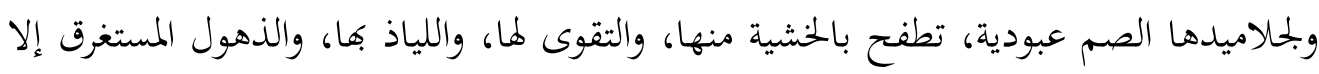

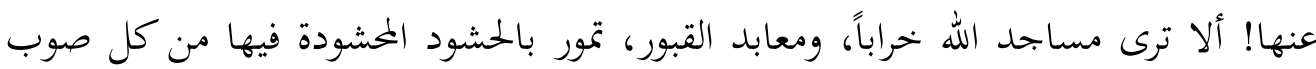

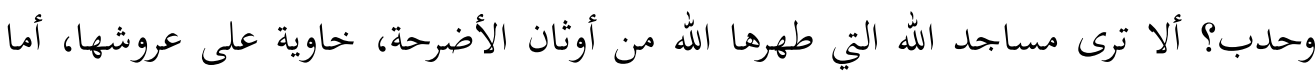

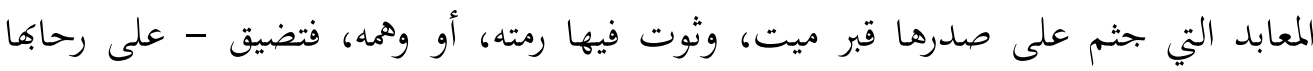

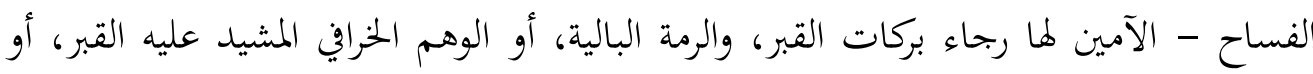

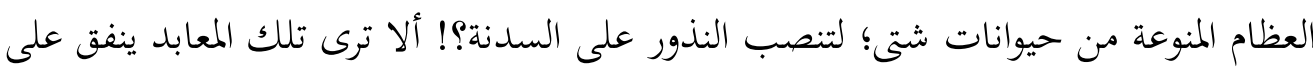

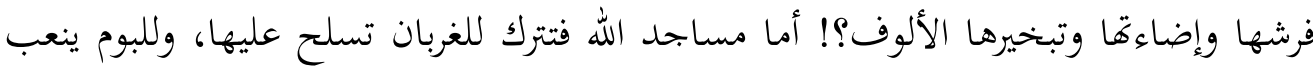
فيها!

ما عبادة الصوفية؟ أهي تلك النذور يحفدون بها إلى الجيف؟ أهي هذا السجود على عتبات

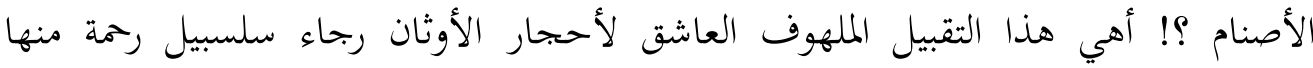

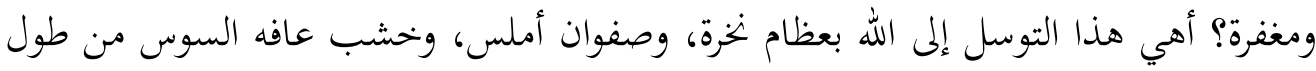

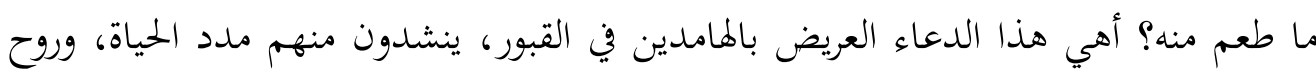

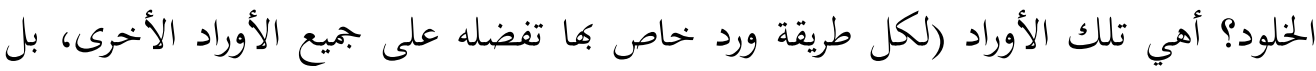

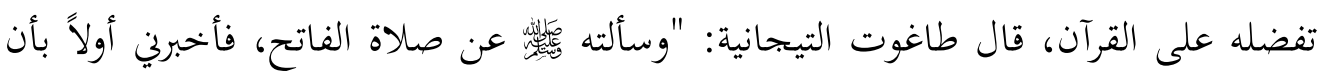

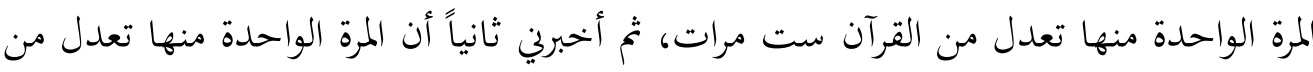

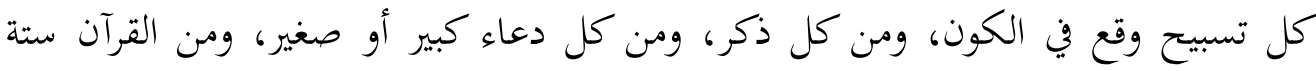

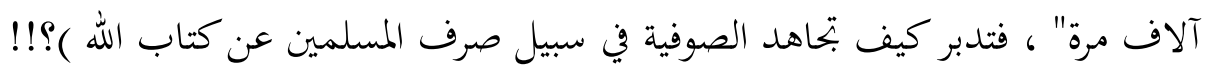

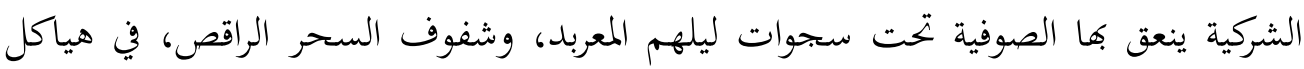

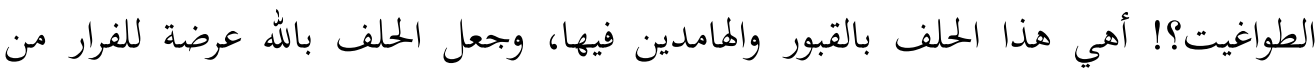

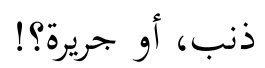
ذلك هو الجانب العملي من التصوف في ذكره وزهده وعبادته، أتراه يصلح لهداية الإنسانية،

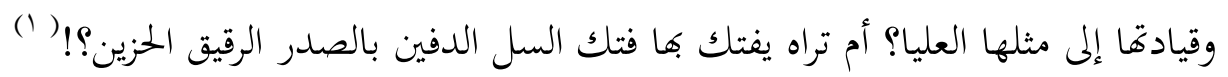

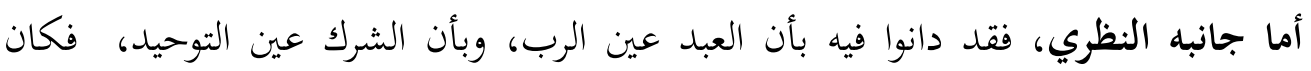

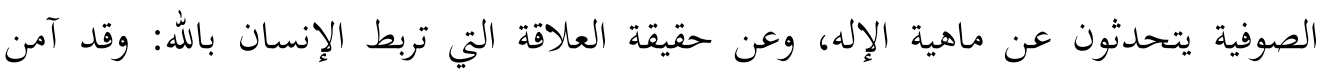

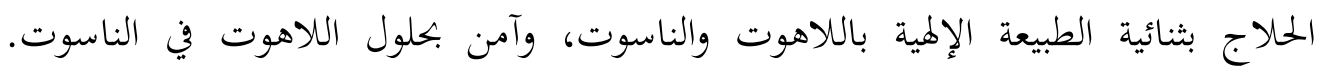


11.

والحلاج في هذا متأثر بالمسيحيين السريان الذين استعملوا اللاهوت والناسوت؛ للدلالة على طبيعتي المسيح. يقول في الطواسين :

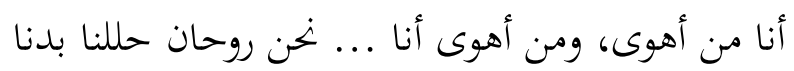
فإذا أبصرتني أبصرته ... وإذا أبصرته أبصرتنا

ويقول - أيضًا- : "أنا الحق، وصاحبي وأستاذي إبليس وفرعون" (1) . نسأل الله السلامة والعافية .

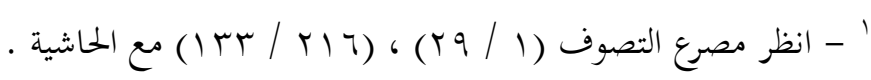


الفصل الخامس : علاقة الصوفية بالشيعة .

إنَّ صلة الصوفية بالتشيع شيء مؤكد، فمرجعهم دائماً من الصحابة هو علي بن أبي طالب أو

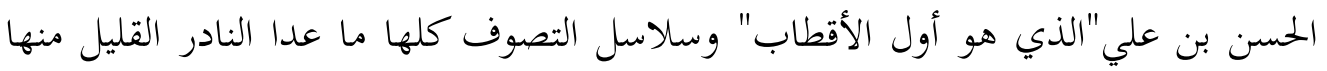
تنتهي إلى علي بن أبي طالب رضي الله عنه دون سائر أصحاب رسول الله صلى الله عليه وسلم، وفي طرق إسنادها إلى علي أسماء أئمة الشيعة المعصومين حسب لهب زعمهم من أولاد علي رضي الله عنه دون غيرهم، وأن رؤساء هذه العصابة يذكر لهم اتصال وثيق، وصلات وطيدة مع أئمة القوم كما يذكر في تراجهم وسيرهم وأحوالهم، إضافة إلى ذلك أن الخرقة الصوفية لا يبدأ ذكرها أيضا إلا من علي رضي الله عنه -أيضا-ـ ( '). ومن عقائد الصوفية أفم يذهبون إلى القول بأن التوحيد مراتب أدناها مرتبة عندهم هو مدلول

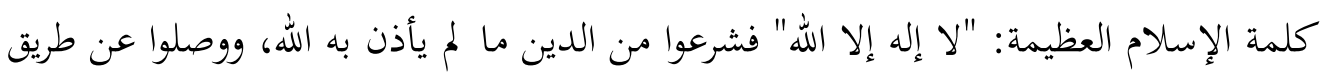

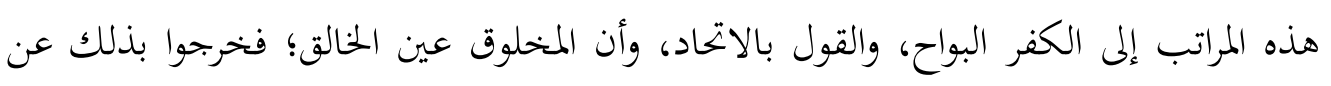
العقل والنقل، والدين، وفاقوا النصارى في شركهم الذين قالوا بحلول الإله في عيسى؛ لأن النصارى قالوا بحلول خحاص وهؤلاء قالوا بالحلول العام. ولكن شيوخ الشيعة الذين ينقلون لمذه الطائفة على مر العصور وكر الدهور حثالة المذاهب المبتدعة، وزبالة الأفكار البشرية الساقطة، وغثاء النفوس المعقدة.. أخذوا بهذا الاتحاه الصوفي المريب، ونقلوه إلى قومهم، بل عدوه هو عقيدةم المعتمدة. يقول شيخهم وآيتهم إبراهيم الزبحاني"إن مراتب التوحيد أربع.. توحيد العوام وتوحيد الخواص، وتوحيد خاص الخاص، وتوحيد أخص الخواص، والأول مدلول كلمة لا إله إلا الله" . .

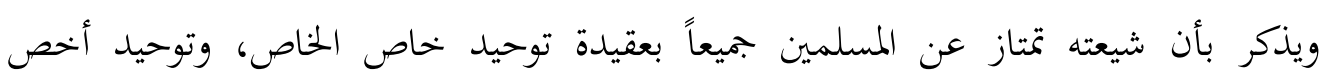
(r) الخواص (بد)

\section{ومن وجوه العلاقة مع الثيعة ظاهرة دعوى النبوة .} لقد أفرزت لوثات التصوف، وخيالات الفلسفة دعوى غريبة، وكفراً صريحاً، حيث أفها ترسم

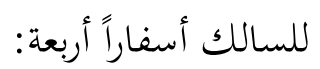

' - دراسات في التصوف والفلسفة (1 / ( I ).

ץ - أصول مذهب الشيعة الإمامية الإثني عشرية عرض ونقد (r / هب • (). 
ينتهي السفر الأول إلى مقام الفناء "وفيه السر الخفيّ والأخفى... ويصدر عنه الشطح، فيحكم

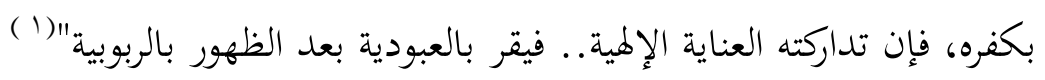

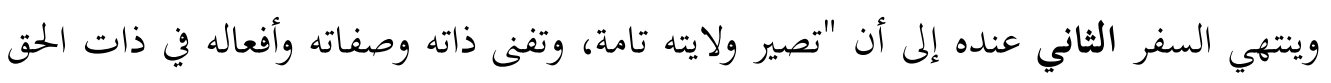

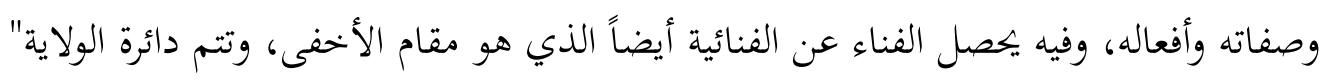
أما في السفر الثالث فإنه "يحصل له الصحو التام ويبقى بإبقاء الله، ويسافر في عوالم الجبروت والملكوت والناسوت، ويكصل له حظ من النبوة، وليست له نبوة التشريع، وحينئ ينتهي السفر

$$
\text { وبالنفر الرابع "يكون نبياً بنبوة التشريع" الرابع }
$$

فمراحل السفر عنده: الفناء، والولاية وفيها الفناء عن الفناء، والنبوة بلا تشريع، ثم النبوة الكاملة، وهي تتضمن أن النبوة مكتسبة عن طريق "رياضات" وبحاهدات أهل التصوف. وهي دعوى ترتد إلى أصول فلسفية صوفية قديمة، ولذا قال القاضي عياض: "ونكفر... من ادعى النبوة لنفسه، أو جوز اكتسابها والبلوغ بصفاء القلب إلى مرتبتها كالفلاسفة وغلاة الصوفية"

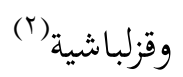
كما أخذ الصوفية مسألة عصمة الولي من الشيعة الذين يقولون بعصمة الأئمة ولكنهم أخفوها فترة من الزمن فسموها(الحفظ) ثم صرح بها القشيري فقال:"واعلم أن من أجل الكرامات التي تكون للأولياء دوام التوفيق للطاعات والعصمة من المعاصي والمخالفات، ويجوز أن يكون من فئ جملة كرامات ولي الله أن يعلم أنه ولي".

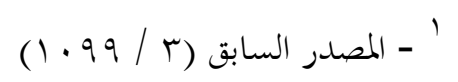

ץ -القزلباشية: هم صوفية متشيعة من أتباع الصفويين، ولفظ القزلباش معناه الرؤوس الحمر، لتغطية رؤوسهم

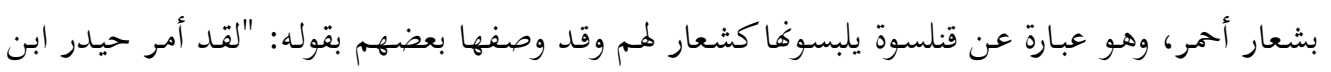

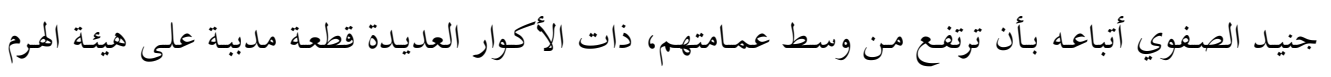

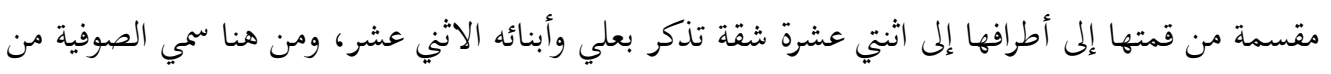

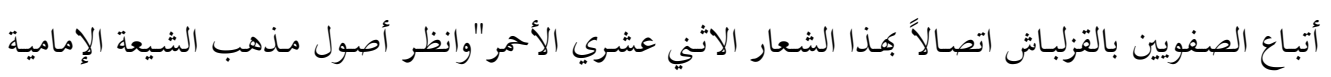

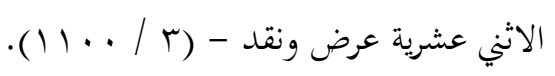


ومن الموافقات الغريبة أن كل زعماء الطرق الصوفية يرجع نسبهم إلى علي بن أبي طالب ويتوارثون زعامة الطريقة كالإمامة عند الشيعة، وإذا كانت المشيخة هي محصول المحاهدة والسلوك فهل ولد الشيخ يجب أن يكون شيخاً؟ إن الشيخ عبد القادر الجيلاني يرجع نسبه إلى آل البيت، وكذلك الشيخ أحمد الرفاعي

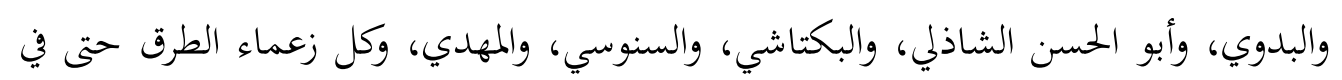
البلاد الأعجمية مثل محمد نور بخش، وخواجه إسحاق وباليم سلطان. والثلاثة الذين اشتهروا في التاريخ الإسلامي باسم الصوفي ولقبه بادئ ذي بدء كان اثنان منهم

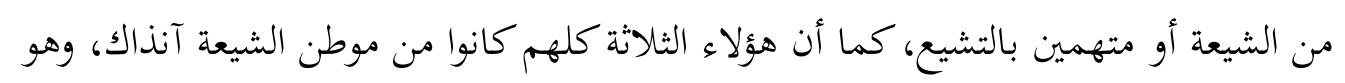

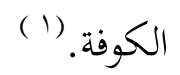

$$
\text { الفصل السادس : الفرق بين الزهد والتصوف . }
$$

إن الزهد عبارة عن : ترجيح الآخرة على الدنيا ، والتصوف اسم لترك الدنيا تماما ، والزهد هو تجنب الحرام ، والاقتصاد في الحلال ، والتمتع بنعم الله بالكفاف ، وإشراك الآخرين في آلاء الله

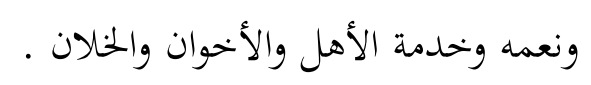
والتصوف تحيم الحلال ، وترك الطيبات ، والتهرب من الزواج ومعاشرة الأهل والإخوان ، وتعذيب النفس بالتجويع والتعري والسهر • فالزهد منهج وسلوك مبني على الكتاب و السنة ، وليس التصوف كذلك ، لذلك ؛ فعندما نتحدث عن هذا المذهب أي: مذهب التصوف لا عن الزهد ، لأن الزهد كما ورد في حديث

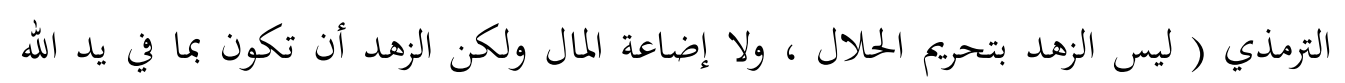

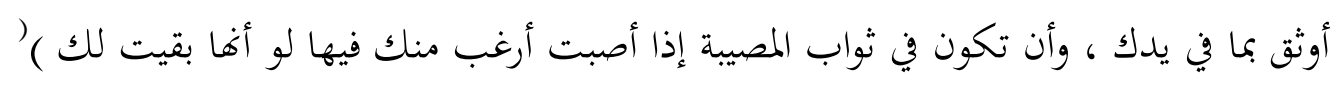

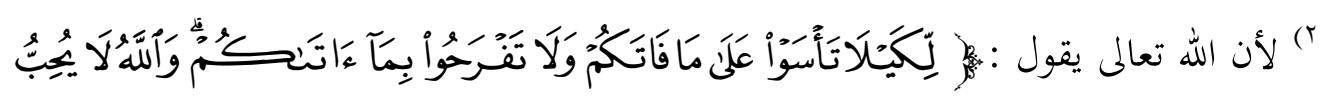

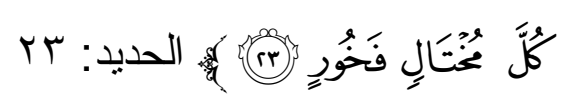

فالتصوف مذهب معروف يزيد على الزهد ويدل على الفرق بينهما أن الزهد لم يذمه أحد وقد

$$
\text { ذموا التصوف (r) (ب) }
$$

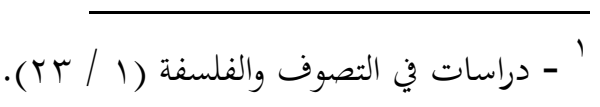

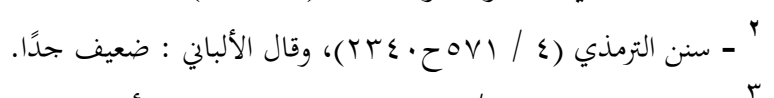

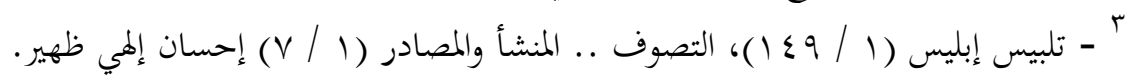


$11 \varepsilon$

الفصل السابع : مصطلحات الصوفية .

اعلم أنّ ألفاظ الصوفية وعلومهم تختلف، فيطلقون ألفاظهم على موضوعات لهم، ومرموزات وإشارات تجري فيما بينهم، فمن لم يداخلهم على التحقيق، ونازل ما هم عليه رجع عنهم خاسئا وهو حسير ، ومن مصطلحاهم :

$$
\text { ا - مصطلح الؤية }
$$

ومن ذلك إطلاقهم لفظ الرؤية بالتقييد فقال: كثيرا ما يقولون: رأيت الله، وذُكر عن جعفر بن

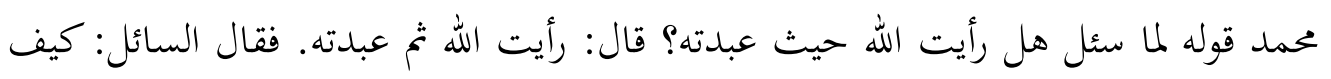

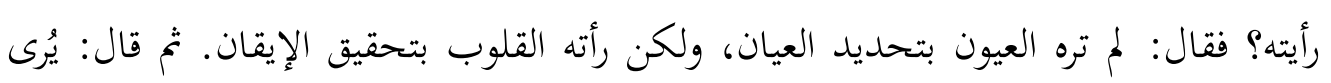
في الآخرة كما أخبر في كتابه وذكره رسول الله - صلى الله عليه وسلم - فهذا قولنا وقول أئمتنا دون الجهال من أهل الغباوة فينا. بمعنى كأنه يقول: إن الصوفية لديهم مصطلحات يختلف معناها الحقيقي عما يظهر منها، لكن يقال: يمكن أن يسلم هذا للمتقدمين ممن كان تصوفهم أميل إلى الاعتدال، وهو عبارة عن الزهد فقط. أما المتأخرون فلا يسلم لمم ذلك -وإن زعموه-؛ لأن كلامهم وكتبهم تأبى أن يكون لها معنى غير هذه المعاني الباطلة، كما هي الحال مثلا في "فصوص الحكم" لابن عربي، و "الفتوحات المكية"، وكتب الحلاج وكتب ابن سبعين وكتب السهروردي وكل هؤلاء المتأخرين؛ فإها تفوح بالإلحاد والضلال، ولا يسلم لهم أن هذه رموز ومصطلحات؛ لأها أمور لا تحتمل

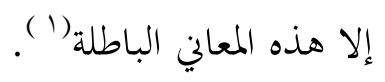

وهذا ما ذكره ابن القيم في قضية معاينة القلب، وهي أن تنكشف صورة المعلوم له بحيث تكون نسبته إلى القلب كنسبة المرئي إلى العين، ولفذا يقول ابن القيم: "وقد جعل الله سبحانه

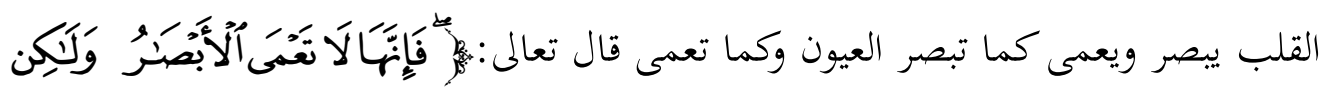

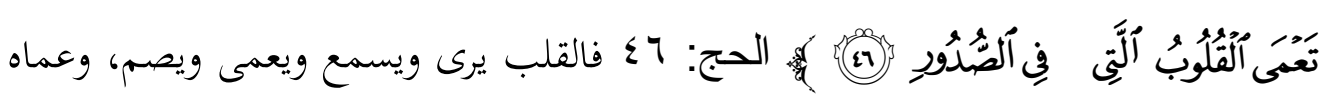
وصممه أبلغ من عمى البصر وصممه"، ثم ذكر أن مشاهدة القلب لجلال البعل الرب وجماله وكماله وعزه وسلطانه وقيوميته وعلوه فوق عرشه وتكلمه بكتبه، وذكر شيئا من نعوته وصفاته.

$$
\text { ' - شرح الفتوى الحموية (1 / ع - } 1007 \text { ـ }
$$




\section{0}

ثم قال: "فصاحب هذا الشاهد سائر إلى الله في يقظته ومنامه، وحركته وسكونه، وفطره وصيامه، له شأن وللناس شأن آخر". (1 ) الشاهد أنه يقول: إن الإنسان كلما ازداد علما وكلما ازداد معرفة بالله - عز وجل - كلما قوي إيمانه، وكلما انفتحت له من أبواب الإيمان وأبواب إلهاب المشاهدة التي لا تنفتح لغيره، لكن لا يُسلَّم هذا التأويل للمتأخرين من الصوفية لماذا؟ لأن

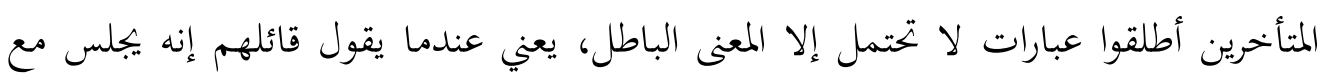

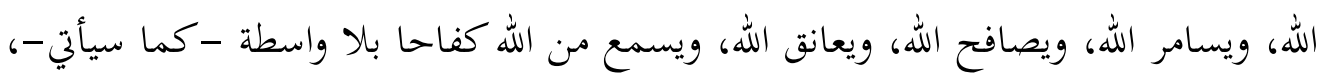

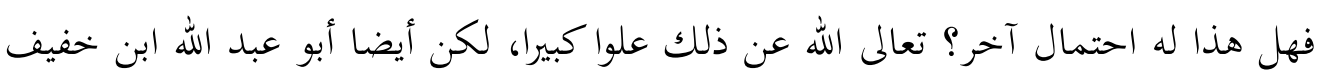
يؤكد على هذا المعنى: أن المتأخرين من أهل هذه الطائفة -التي هم الصوفية- أدخلوا في هذا

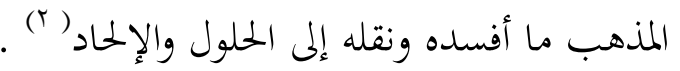

$$
\text { (التواجد }
$$

التواجد أيضا من مقامات الصوفية، ومصطلح من مصطلحات الصوفية، وهو: يقولون من وَجَدَ وَجْدا أو وِجْدا، بالفتح يعني الحِب وبالكسر يعني الحزن، عندهم التواجد عند الصوفية استجلاب الوجد بالذكر والتفكر، يجتمعون وإما أن يغنوا ويرقصوا ويطربوا أو يقومون يرددون بعض الأذكار جماعيا أو حتى فرديا ذكر مخصوص، يزعمون أفم يستجلبون بذلك - تعالى اللهالروح الإلهية، وأفم يرتفعون عن هذا العالم، ويحلقون عن هذا الوجود إلى عالم آخر. ولهذا أحيانا عن طريق هذا الوجد يصلون إلى حالة ما يسمى (الإسطيلان) السكر مصطلحات صوفية، يغيب الواحد عن الحالة الموجودة والناس الموجودين، ويعيش في عالم آخر حتى أحيانا

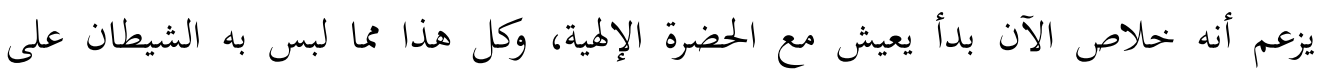

هؤلاء. (r)

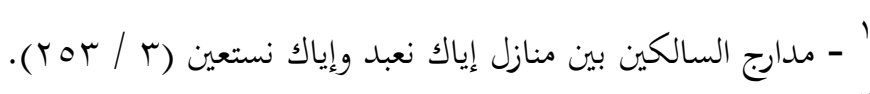

$$
\begin{aligned}
& \text { r - الفتوى الحموية مع شرحها (1 / ع ع ع). } \\
& \text { ץ - الفتوى الحموية مع شرحها (1 / عVV). }
\end{aligned}
$$




\section{7}

ب- الفناء

أرادوا بالفناء نفي حقائق الأشياء، وجعلوها خيالا وسرابا على ما هو مذهب السوفسطائية . والفناء عندهم عبارة عن اضمحلال الكائنات في نظرهم مع وجودها، وعن الغيبة عن نسبة أفعالهم إليهم، وكذا الوحدة المطلقة عبارة عن مشاهدة الله -لا غير- من بين الموجودات لاضمحلالفا مع تحققها ووجودها عند ظهور أنوار التجليات، كاضمحلال الكواكب مع وجودها عند ظهور نور الشمس في النهار، فإن كان العارف في هذه الحال يرى نفسه، فذلك هو الفناء في التوحيد، وهو مرتبة الخواص، وهو مشوب بكدورة وقصور، وإن غاب مع ذلك عن مشاهدة نفسه وعن أحواله الظاهرة والباطنة وعن ذلك الفناء -بحيث لا يشاهد شيئا غير الله كما لا يشاهد في النهار من الكواكب غير الشمس- فذلك هو فناء الفناء في التوحيد،

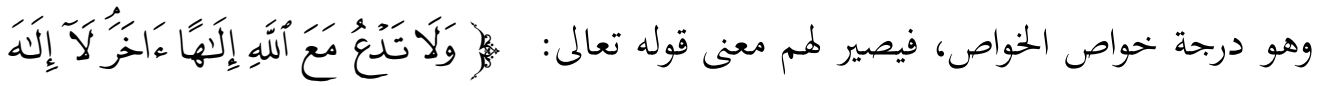

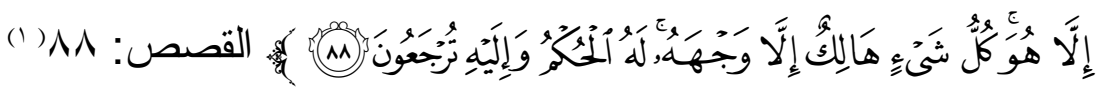

$$
\text { ع - الفقر }
$$

وقد لبس إبليس على الصوفية ، فمنهم من يظهر الفقر وهو غني فان أضاف إلى هذا السؤال

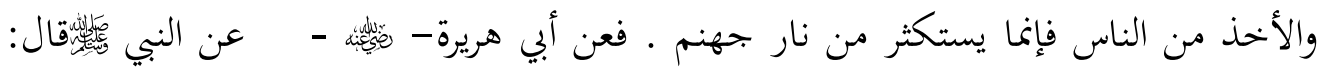

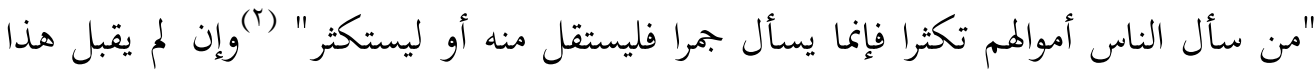
الرجل من الناس شيئا وكان مقصوده بإظهار الفقر أن يقال : رجل زاهد فقد راءا وإن كتم نعمة الله عنده ليظهر عليه الفقر لئلا ينفق ففي ضمن بخله الشكوى من الله. فالمتسب له كتمان الفقر وإظهار التجمل فقد كان في السلف من يحمل مفتاحا يوهم أن له دارا ولا يبيت إلا في المساجد.

ومن تلبيس إبليس على الفقراء : أنه يرى نفسه خيرا من الغني إذ قد زهد فيما رغب ذلك الغني فيه وهذا غلط وأن الخيرية ليست بالوجود والعدم وإنما هي بأمر وراء ذلك. (r) وعليه فالصوفية يجعلون الفقر مرتبة من مراتبهم ، ولذذا سئل سهل بن عبد الله التستري عن الفقير الصادق فقال: هو من لا يسأل ولا يرد ولا يحدث.

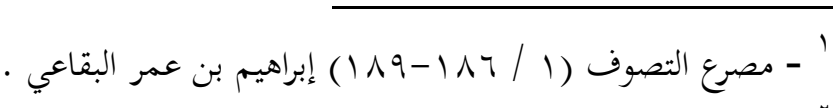

$$
\begin{aligned}
& \text {. }
\end{aligned}
$$

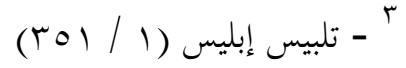


وقال ابن الجلاء: الفقر ألا يكون لك، فإذا لك فلا يكون لك حتى تؤتيه. فمصطلح الفقير أو مسمى الفقير هذه مرتبة من مراتب الصوفية. يقول: إذا احتاج وصبر ولم يتكلف إلى وقت يفتح الله له كان أعلى ممن عجز عن الصبر. لا شك أن الفقر ليس مطلوبا لذاته وليس بمستحسن بالنظر إليه كصفة، بل هي حكاية واقع

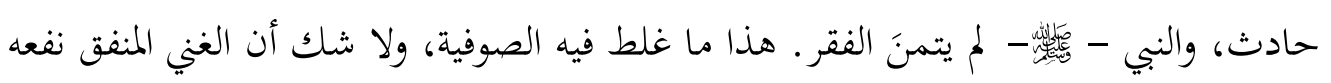
أكثر من نفع هذا الفقير المعدم.

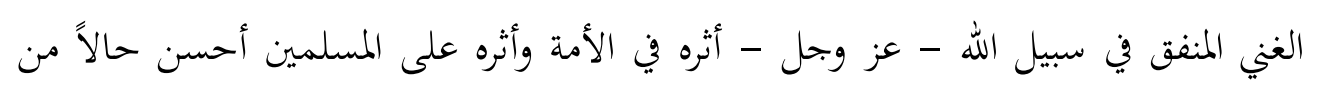
هذا الفقير يقول: على هذا الفقير أن يصبر حتى يفتح الله - عز وجل - له فمن عجز عن الهن الصبر كان السؤال أولى به على قوله - هلئه هريرة:(والذي نفسي بيديه لأن يأخذ أحدكم حبله فيحتطب على ظهره خير له من أن يأتي

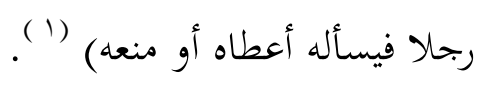
فالتكفف عما في أيدي الناس والضرب في الأرض وفعل الأسباب هذا هو الأمر يقول، ونقول: إن ترك المكاسب غير جائز إلا بشرائط مرسومة من التعفف والاستغناء عما في أيدي الناس. ومن جعل السؤال حرفة وهو صحيح فهو بحنون في الحقيقة خارج عن الطريقة الصوفية ولا شك أن أهل التصوف يرون أن الجلوس وترك التكسب أن هذا أمر . وأمر مطلوب وهذا خطأ

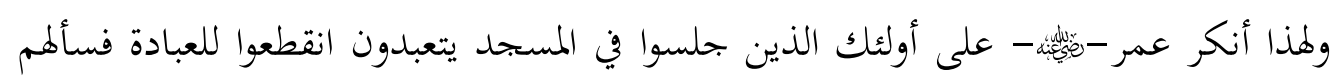

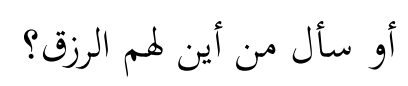

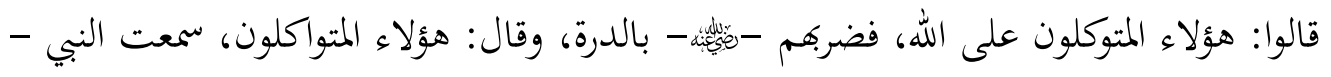

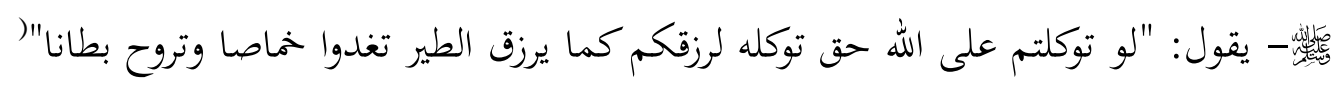
التوكل هذا هو التوكل الصحيح، وهذا هو التوكل الشرعي. فكون هؤلاء يجلسون بالمساجد أو يجلسون في الزوايا يسألون الناس يتكففون الناس ويزعمون

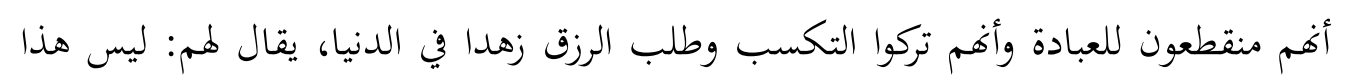

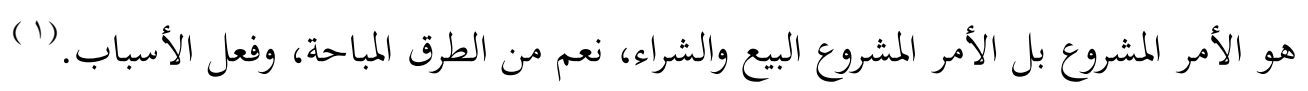

$$
\text { (r.V० }
$$

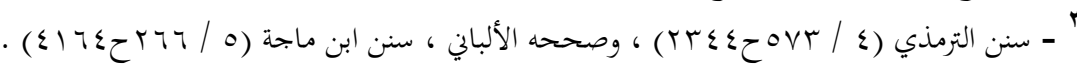


111

الفصل الثامن : مصادر التلقي عند الصوفية . إنَّ مصادر التلقي في التشريع عند المسلمين هو $\}$ الكتاب والسنة والإجماع والقياسجو.وأمّا

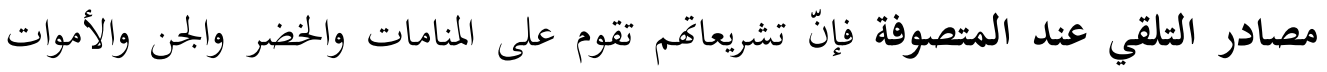

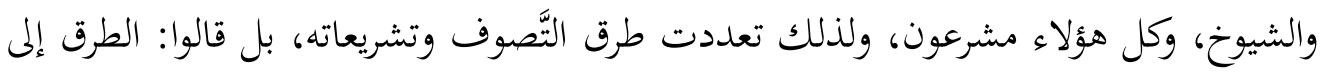

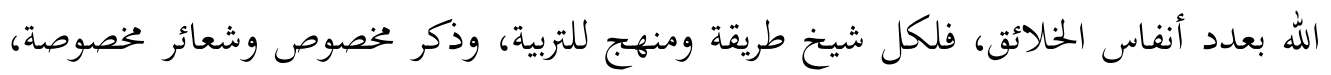

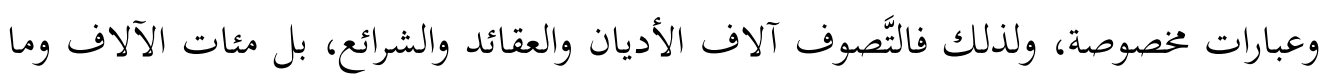

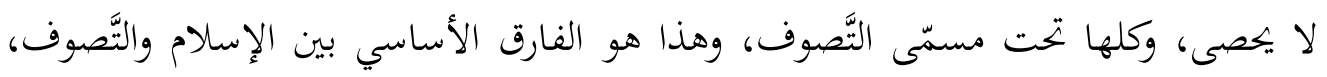

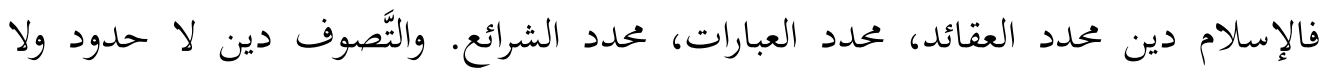
تعاريف له في العقائد أو الشرائع.

أولا: الكشف: ويعتمد الصوفية الكشف مصدراً وثيقاً للعلوم والمعارف، بل تحقيق غاية عبادتم، ويدخل تحت الكشف الصوفي جملة من الأمور الشرعية والكونية منها:1-النبي صلى الله عليه وسلم:ويقصدون به الأخذ عنه يقظةً أو مناماً.

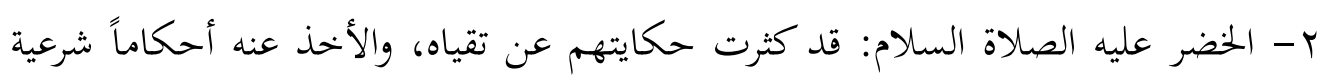
وعلوماً دينية، وكذلك الأوراد، والأذكار والمناقب.

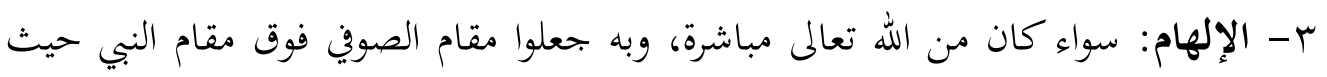

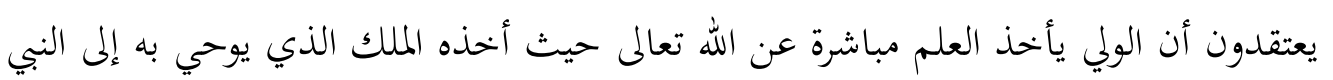

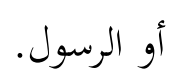

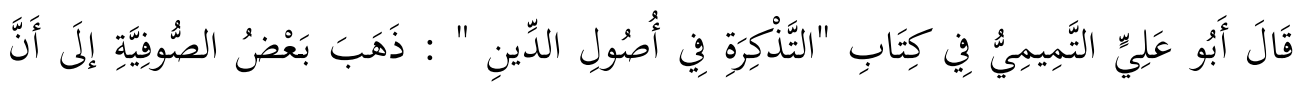

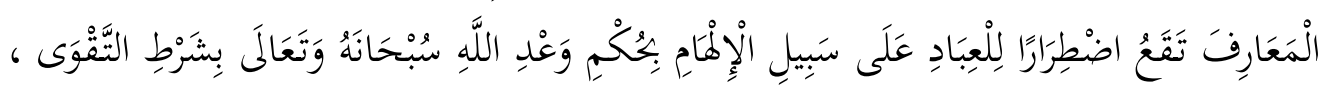

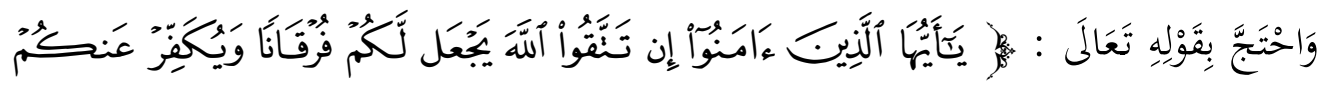

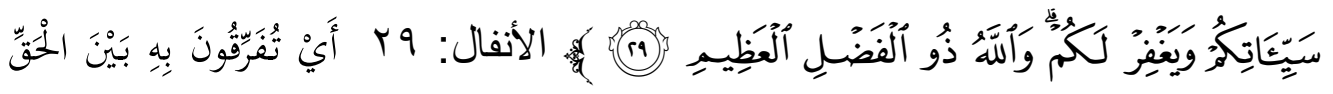

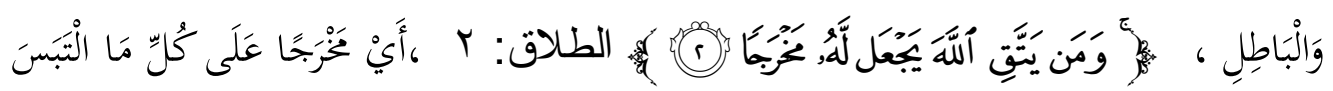

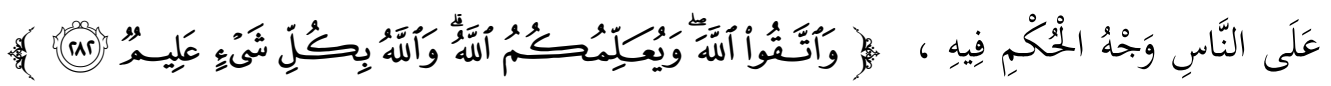




\section{9}

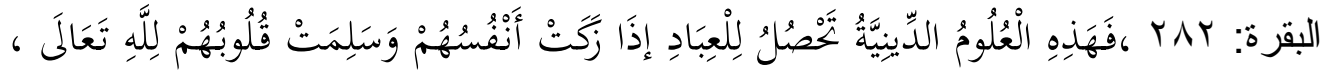

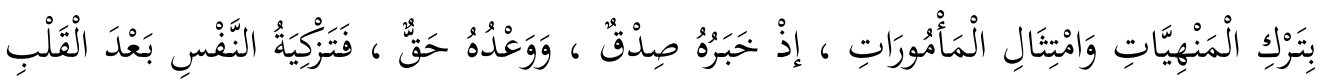

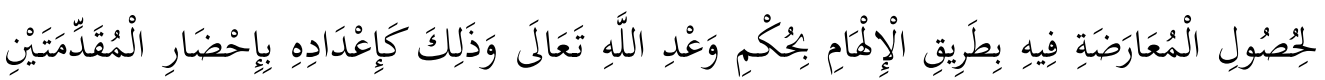

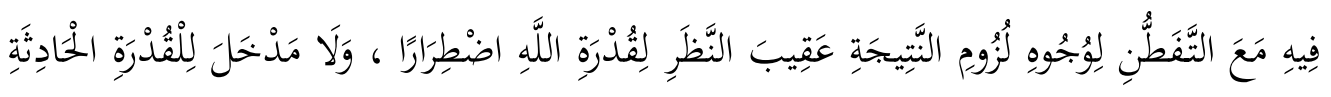

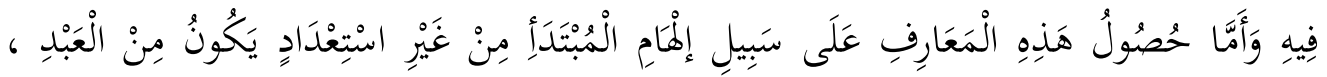

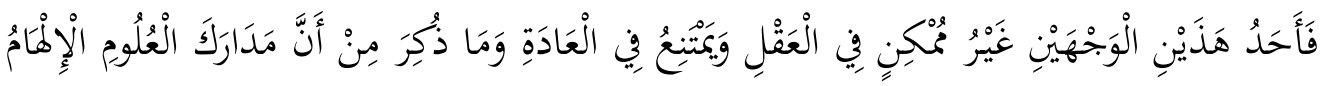

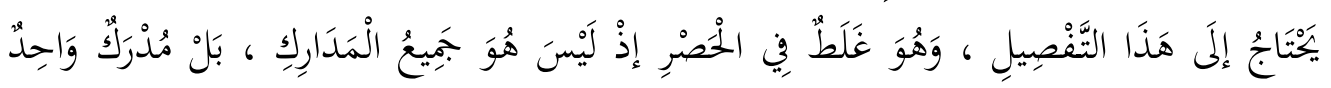

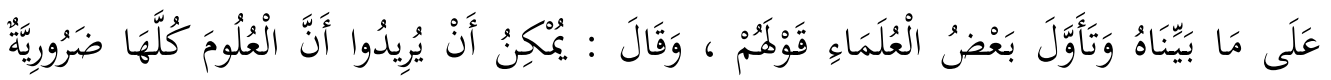

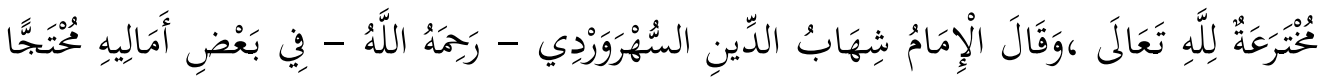

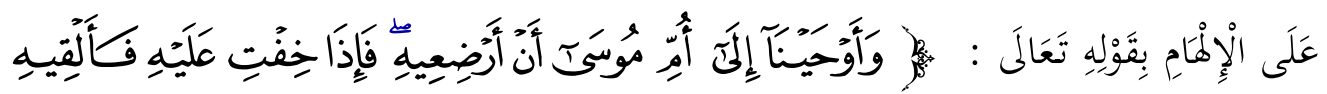

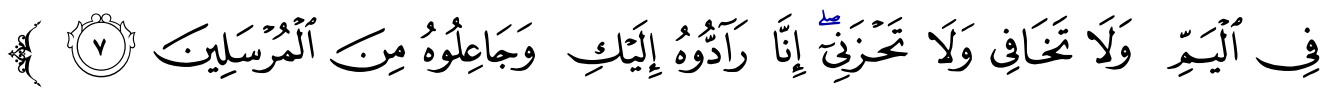

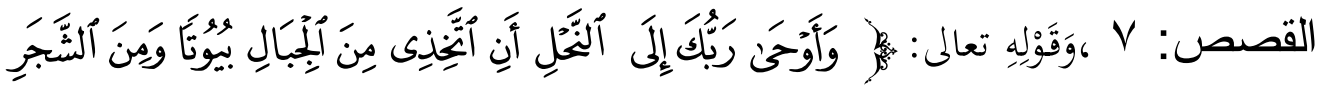

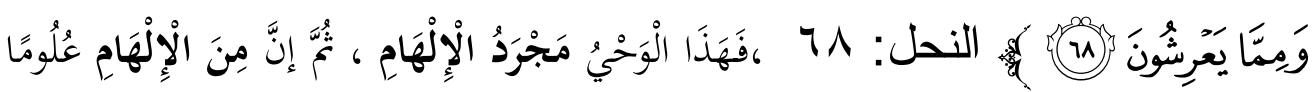

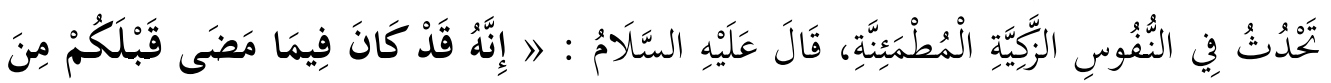

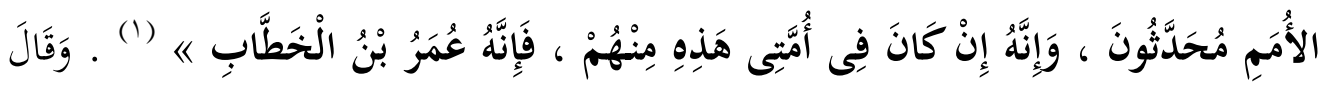

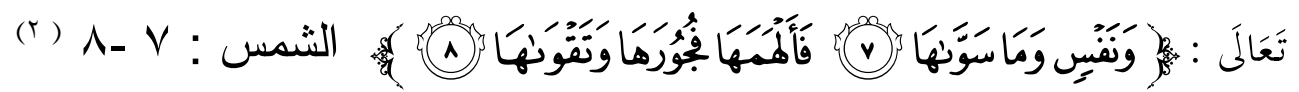
ع -الفراسة: والتي تختص بمعرفة خواطر النفوس وأحاديثها.

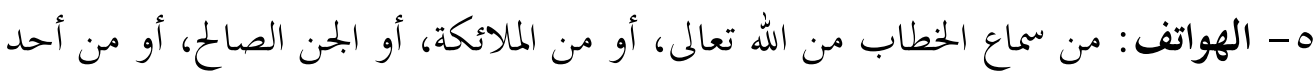

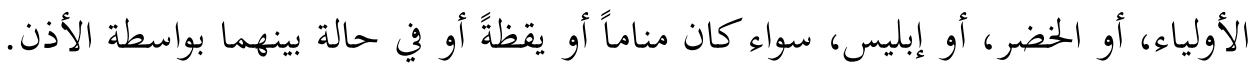

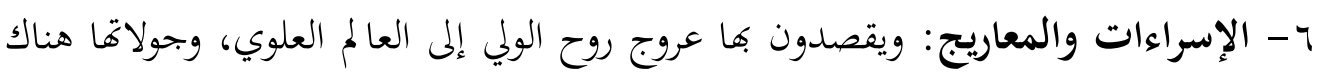
والإتيان منها بشتى العلوم والأسرار.

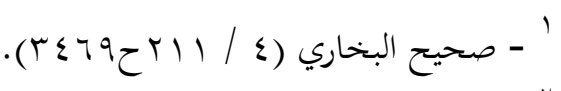

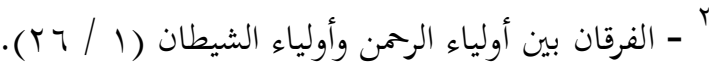




\section{Ir}

- V الكشف الحسي: بالكشف عن حقائق الوجود بارتفاع الحجب الحسية عن عين القلب وعين البصر (1) يقول أبو حامد الغزالي - يرحمه الله - عن الصوفية:"إن ميل أهل التصوف إلى العلوم الإلمامية دون التعليمية، فلذلك لم يمرصوا على دراسة العلم وتحصيل ما صنفه المصنفون والبحث عن يون الأقاويل والأدلة المذكورة، بل الطريق تقديم المحاهدة، ومحو الصفات المذمومة وقطع العلائق كلها والإقبال بكنه الهمة على الله تعالى ومهما حصل ذلك كان الله هو المتولي لقلب عبده والمتكفل له بتنويره بأنوار العلم....وانكشف له سر الملكوت....فليس على العبد إلا الاستعداد بالتصفية البحردة وإحضار الهمة مع الإرادة والتعطش التام والترصد بدوام الانتظار لما يفتحه الله تعالى من

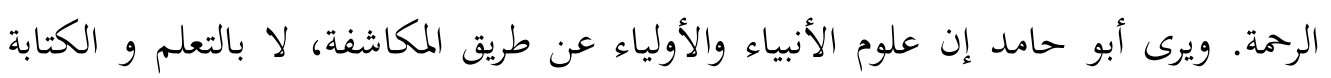

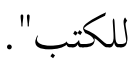

ويقول عبد الرحمن الجامي:"إنّ مستند الصوفية فيما ذهبوا إليه هو الكشف والعيان، لا النظر والبرهان. ويقول ابن عربي في رسالته إلى الفخر الرازي:"ارفع الهمة في أن لا تأخذ علما إلا من الله تعالى على الكشف، وأنه من المحال للعقل والفكر أن يصل إلى ما يطمئن إليه الإنسان في

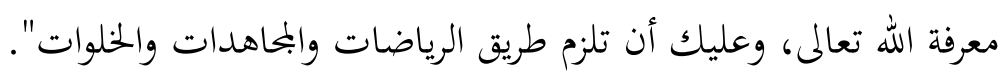
ونقل -أيضًا- عن بعضهم كلمات فيها دلالة على إغفال مصادر التلقي ( الكتاب والسنة) : من التزهيد في العلم والاستغناء عنه كقول من قال : نحن نأخذ علمنا من الحي الذي لا يموت وأنتم تأخذونه من حي يموت وقول الآخر وقد قيل له : ألا ترحل حتى تسمع من عبدالرزاق فقال : ما يصنع بالسماع من عبدالززاق من يسمع من الخلاق، وقول الآخر : العلم حجاب بين القلب وبين الله عز وجل وقول الآخر : إذا رأيت الصوفي يشتغل بأ خبرنا وحدثنا فاغسل يدك منه وقول الآخر : لنا علم الحرف ولكم علم الورق ونحو هذا من الكلمات التي أحسن أحوال قائلها : أن يكون جاهلا يعذر بيجهله أو شاطحا معترفا بشطحه وإلا فلولا عبدالرزاق وأمثاله ولولا أخبرنا و حدثنا لما وصل إلى هذا وأمثاله شيء من الإسلام ومن أحالك

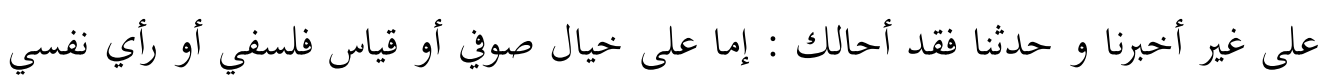
فليس بعد القرآن و أخبرنا وحدثنا إلا شبهات المتكلمين وآراء المنحرفين وخيالات المتصوفين وقياس المتفلسفين ومن فارق الدليل ضل عن سواء السبيل ولا دليل إلى الله والجنة سوى

$$
\text { ' - دراسات في التصوف والفلسفة (1 / .r) صالح الرقب . }
$$




\section{$|r|$}

الكتاب والسنة وكل طريق لم يصحبها دليل القرآن والسنة فهي من طرق الجحيم والشيطان

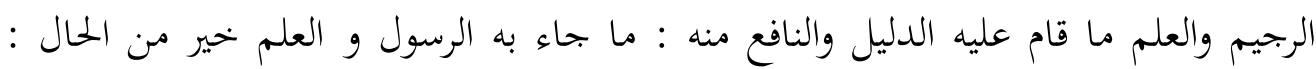

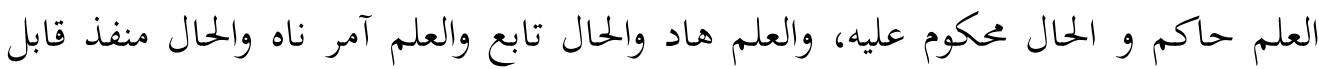

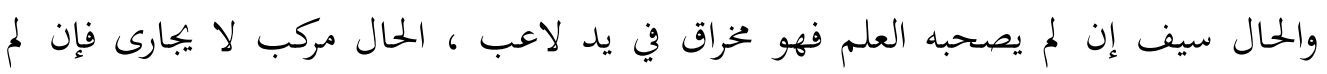

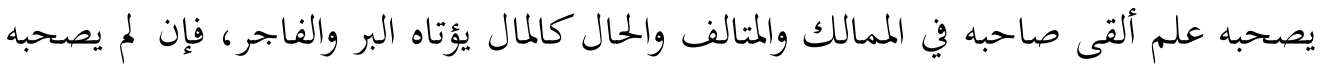

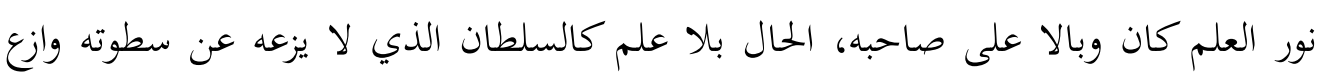

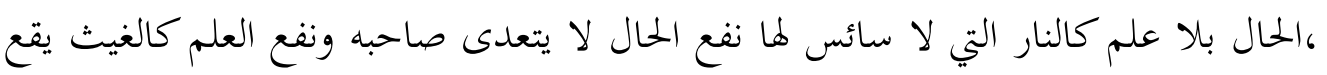

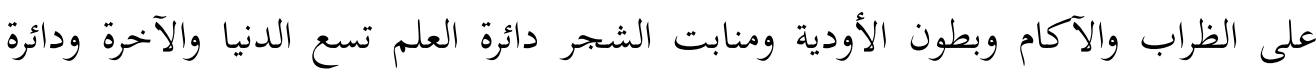
الحال تضيق عن غير صاحبه وربما ضاقت عنه ( '). ثانيا:الذوق: وله إطلاقان:-

1- الذوق العام الذي ينظم جميع الأحوال والمقامات، ويرى الغزالي في كتابه المنقذ من الضلال إمكان السالك أن يتذوق حقيقة النبوة، وأن يدرك خاصيتها بالمنازلة.

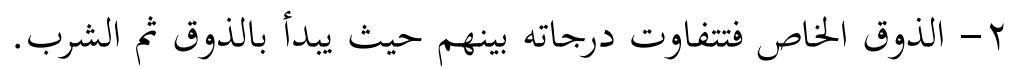

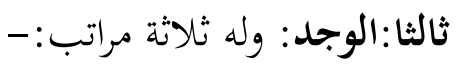
1 - 1 - 1التواجد.

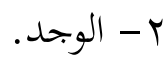

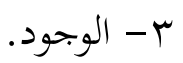

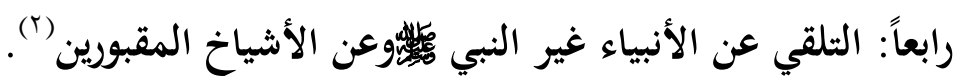

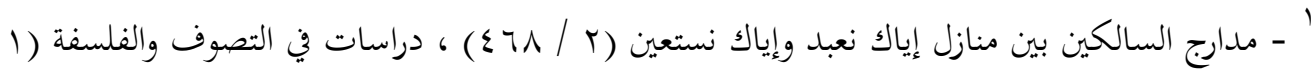


الباب الثاني: موقف الصوفية من السنة النبوية

وفيه فصول ستة: 


\section{Irr \\ الفصل الأول : موقف الصوفية من الصحابة .}

إن الرابط الكبير بين الصحابة رضي الله عنهم ، والصوفية هو الزهد في الدنيا ، إلا أن الصحابة الكرام كانت حياتم وعبادهم وفق ما رباهم عليه النبي

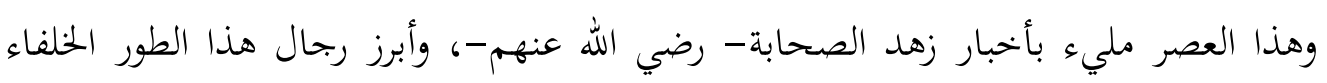
الراشدون ، أبو بكر وعمر وعثمان وعلي ،وكذلك عبد الله بن عباس ، وأبو عبيدة رضي الله

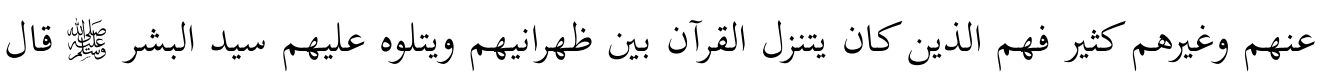

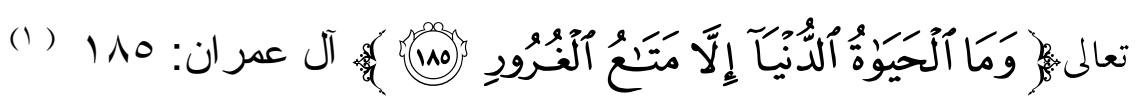
بخلاف الصوفية الذين ترقى بهم الحال حتى وقع من وقع منهم في شطحات نأت بهم عن النروف

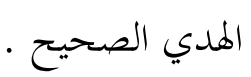

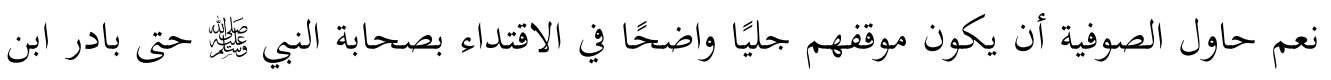
عربي للقول أن أبا بكر وعمر كانوا أقطابًا بالمعنى الصوفي. ( ونقول حاشا الصحابة أن يدخلوا في هذا الزور والبهتان ) (r). لم يكن التصوف معروفاً في عهد رسول الله صلى الله عليه وسلم وأصحابه رضي الله عنهم ولا في عصر التابعين رحهم الله ، وإن كانت حقيقته معروفة ، لأن جل ما يصبوا إليه المرء هو

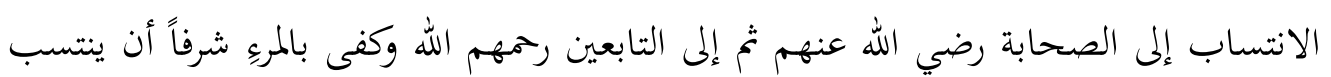

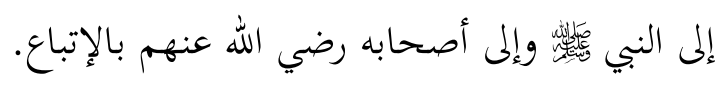

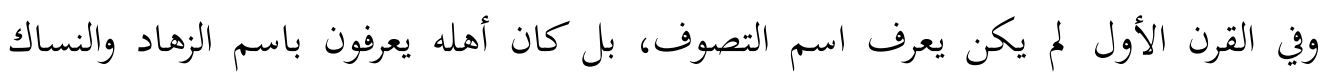

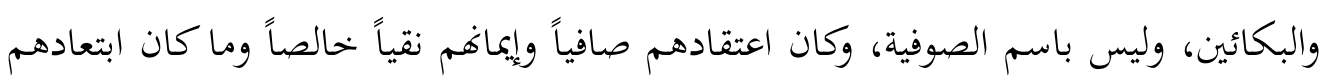

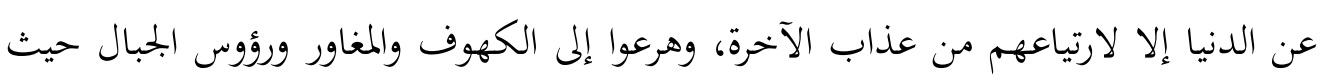
الوحدة الصافية والانعزال عن صخب الحياة المادية . ثم بعد مضي عصر الصحابة والتابعين وين أواخر القرن الثاني الهجري بدأ لفظ الصوفية يظهر ، وقد نقل التكلم به عن غير واحد من الأئمة والشيوخ كالإمام أحمد بن حنبل رحمه الله

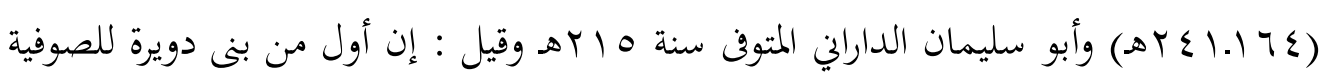

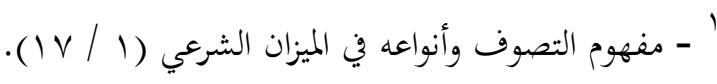
r - دراسات في التصوف والفلسفة (1 / ع ا I ) صالح الرقب. 


\section{IY}

هو بعض أصحاب عبد الواحد بن زيد المتوف بعد الخمسين ومائة للهجرة. وهو من أصحاب

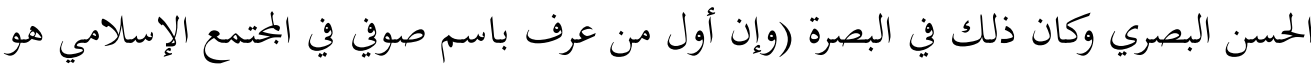

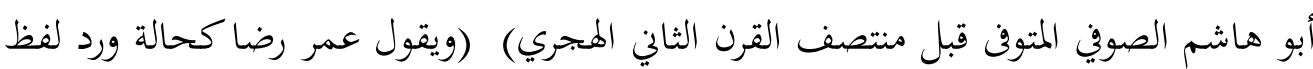

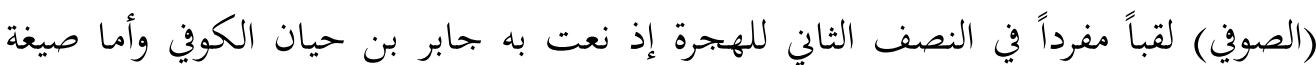

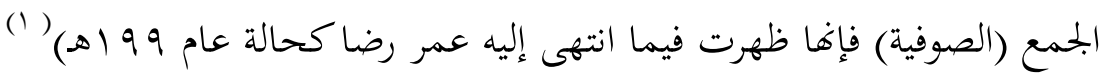

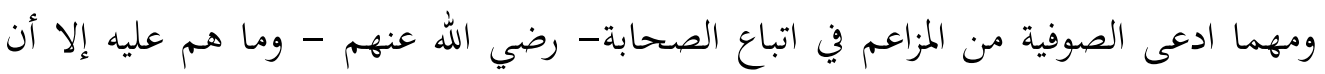

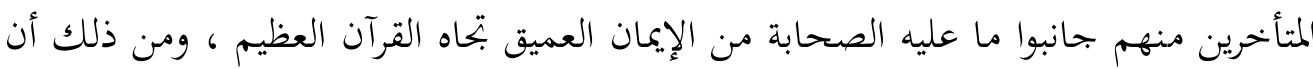
الله سبحانه يصف كتابه بأنه بيان للناس، ويمن علينا بأنه بعث في الأميين رسولا يتلو عليهم

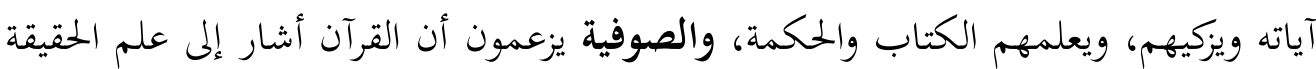

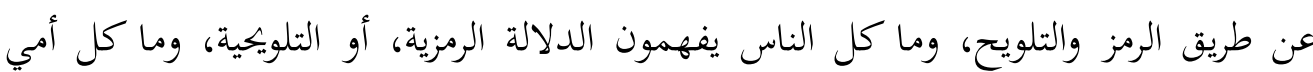
يفهمها، وهذا يستلزم طامتين، الأولى: اتهام القرآن بالعجز في البيان عن الحتيقة، فلم يستطع

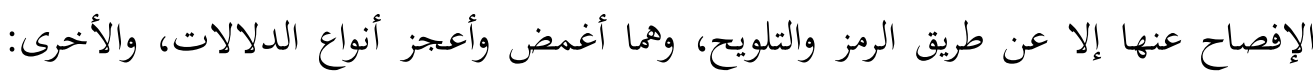

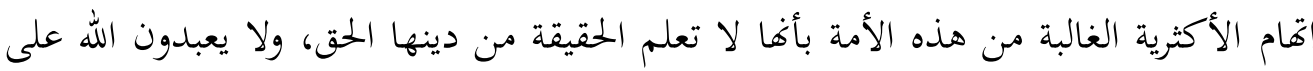

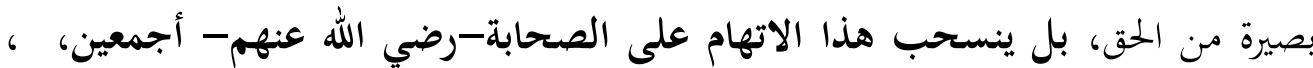

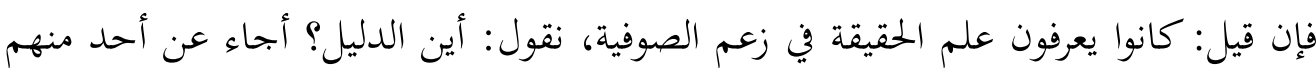
افتراء أن الدين حقيقة وشريعة مغايرا بين القسمين؟ أتكلم واحد منهم عن الفناء، وفناء الفناء،

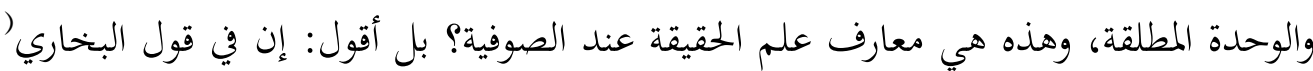

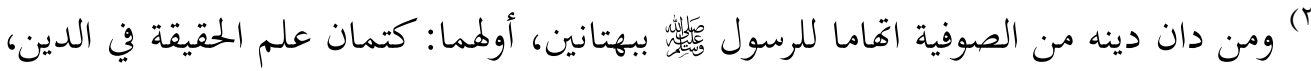

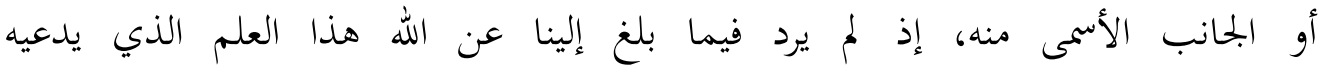

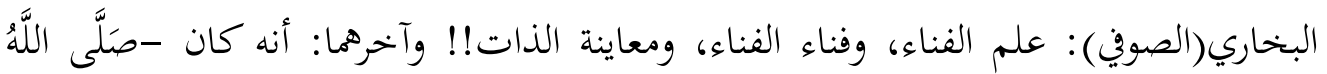

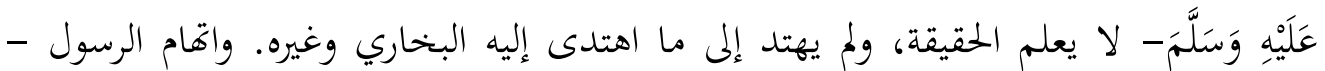

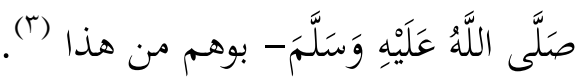

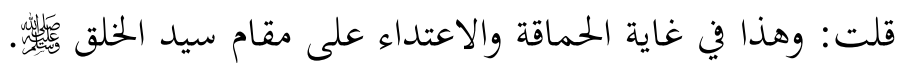

$$
\text { ' - مفهوم التصوف وأنواعه في الميزان الشرعي (1 / 1 1 ). }
$$

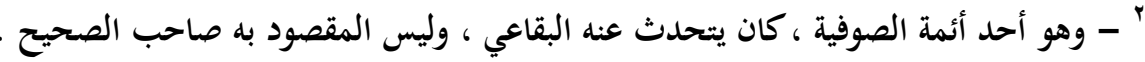

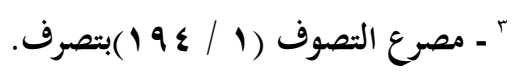




\section{iro}

$$
\text { الفصل الثاني : موقف الصوفية من شرح السنة . }
$$

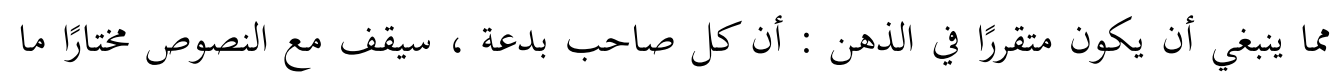

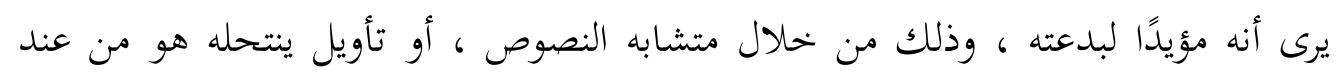

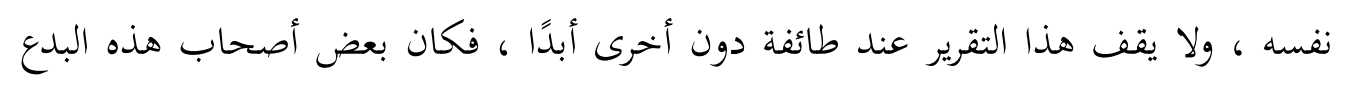

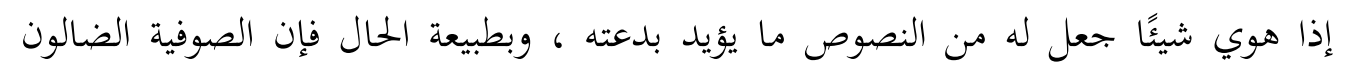

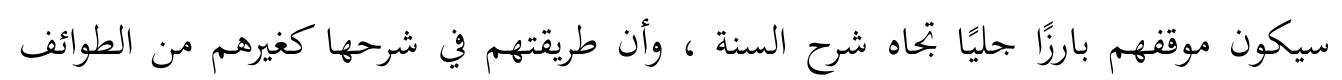

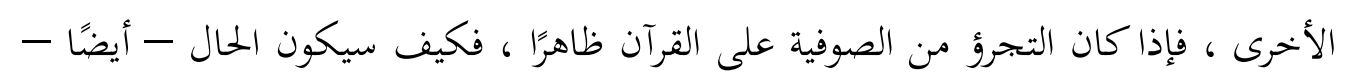

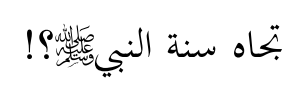
وعلى سبيل المثال انظر إلى صاحب كتاب (الفصوص) وهو يقف أمام نص من القرآن ، قال

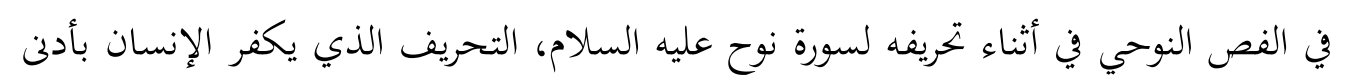

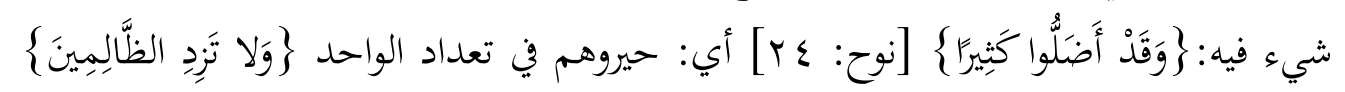

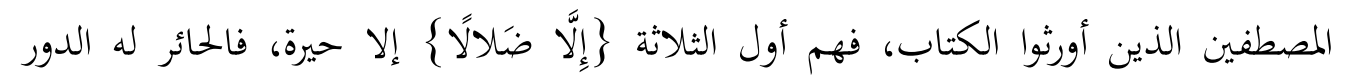

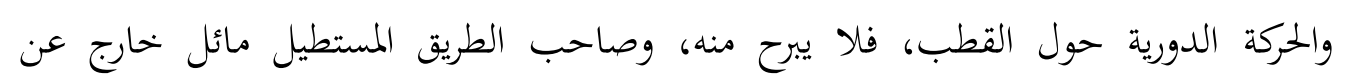

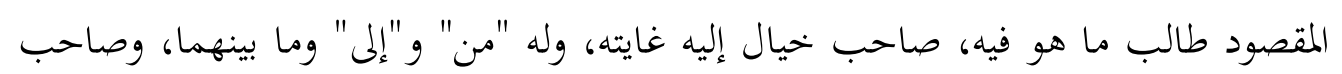

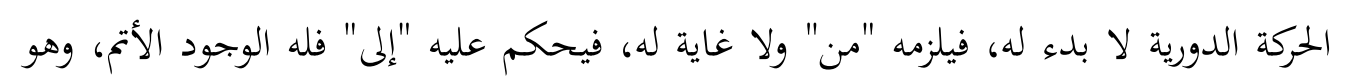

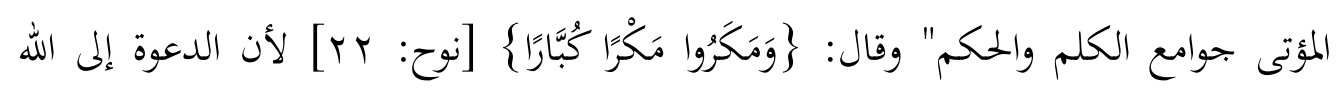

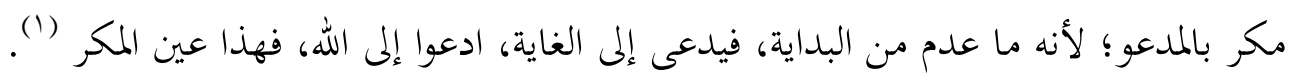

ومن الواضح في كتبهم - أيضًا - عدم عنايتهم بانتقاء الأسانيد في نقل مروياتم ، فلا

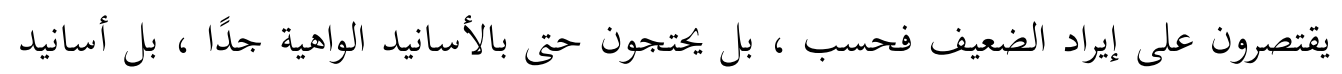

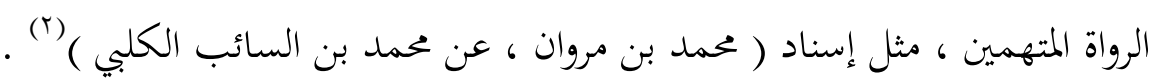

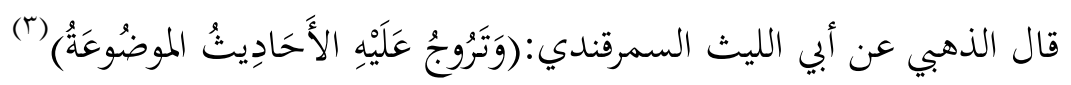

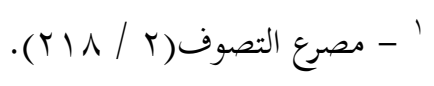

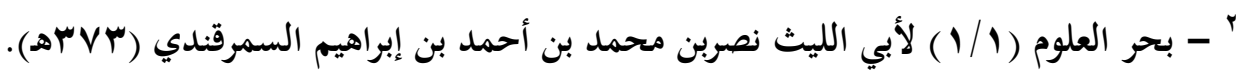

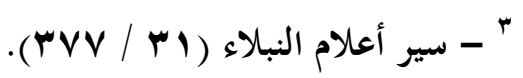


وكذا يستدل بالرؤى والمنامات في تصحيح بعض ما يختاره من وجوه التفسير من ذلك قوله:

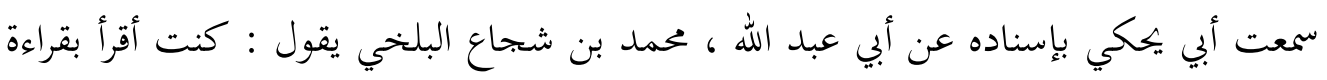

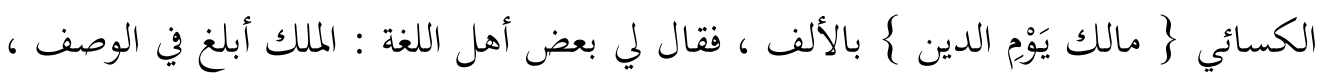

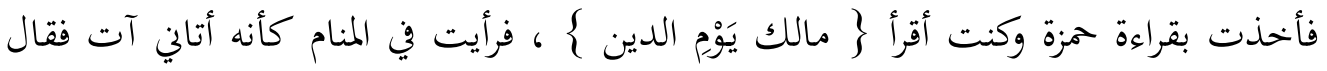

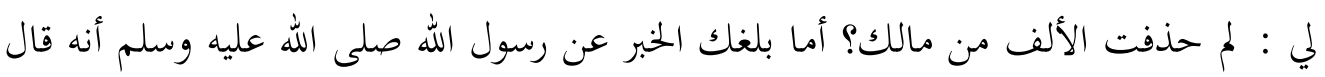

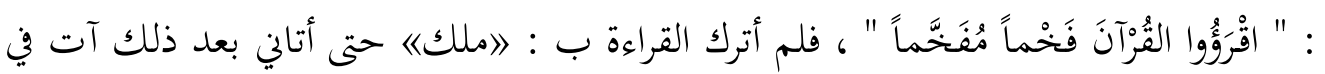

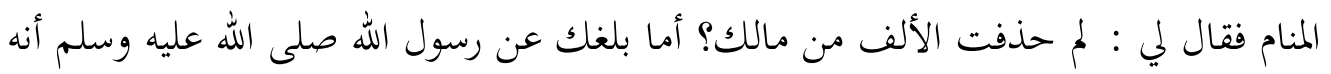

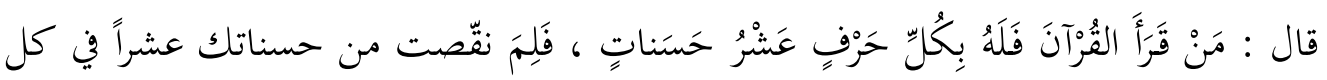

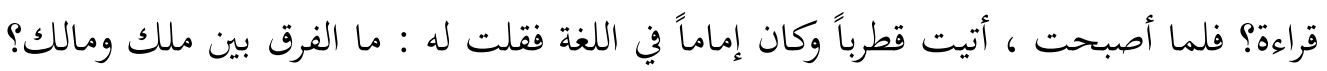

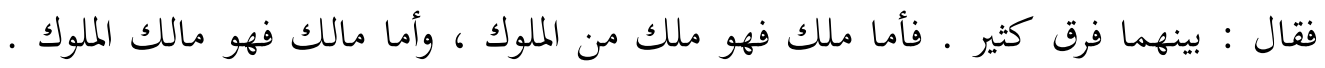

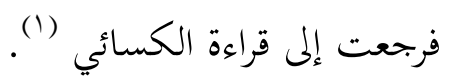

$$
\text { ومن كتبهم - أيضًا - والتي تموج بالبدع كتاب (عوارف المعارف) . }
$$

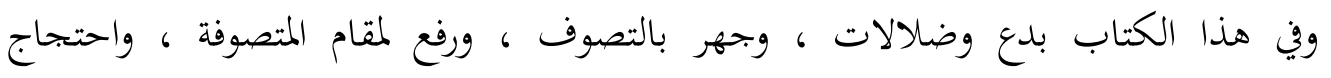
بالنصوص من الكتاب والسنة على شأن الصوفية ورفع مقام أهلها.

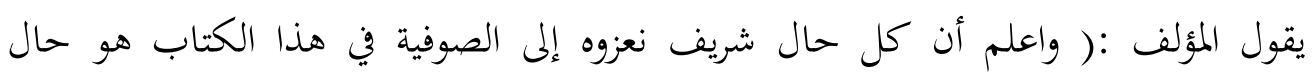

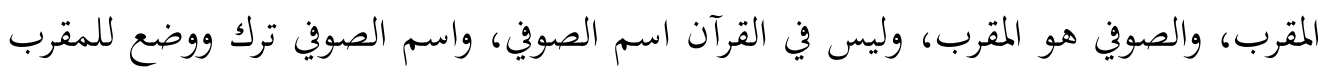

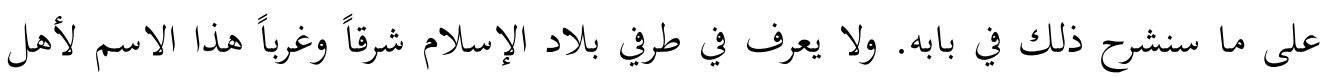

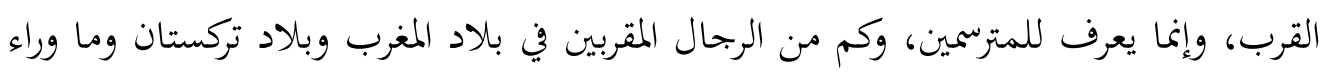
النهر ولا يسمون صوفية، لأفم لا يتزيون بزي الصوفية، ولا مشاحة في الألفاظ فيعلم أنا نعني

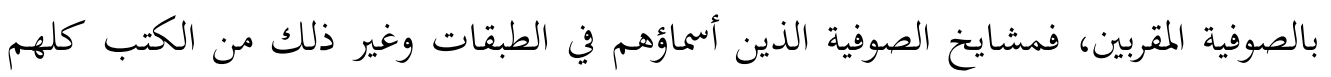

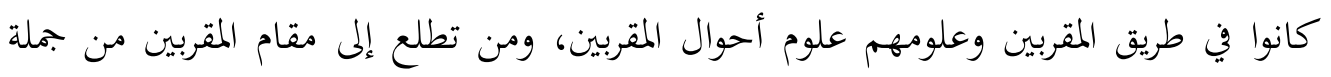

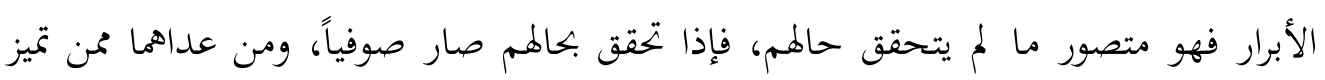

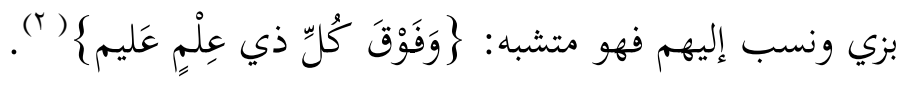

' - بحر العلوم (r/1)

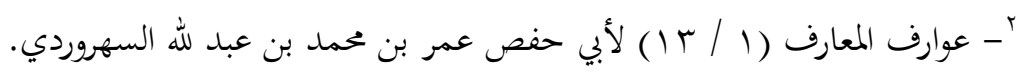




\section{ITV \\ وانظر إلى ما قاله في \}الباب الثاني\{: في تخصيص الصوفية بحسن الاستماع.

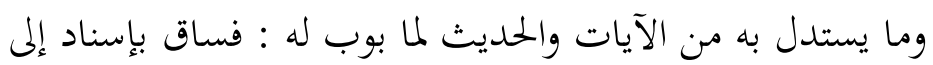

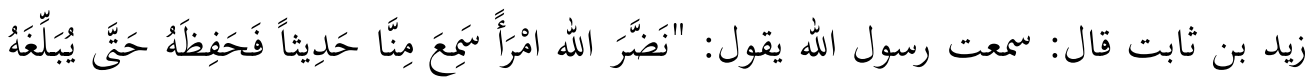

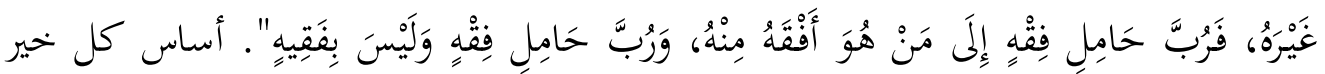

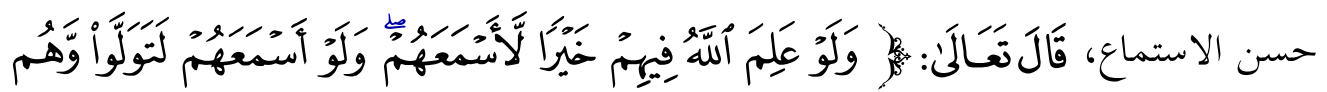

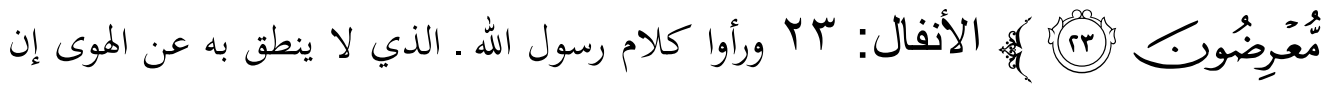

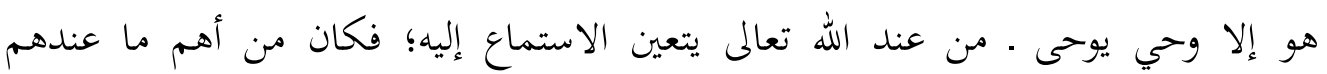

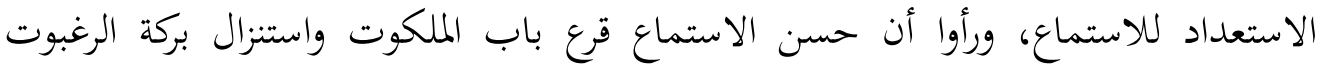

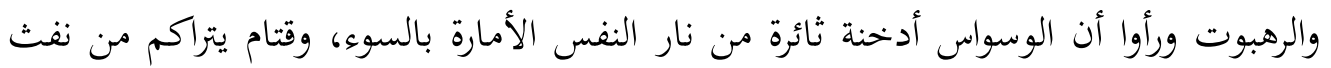
الشيطان، وأن الحظوظ العاجلة والأقسام الدنيوية التي هي مناط الهوى ومثار الردى بمثابة

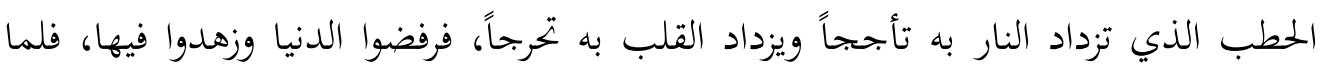

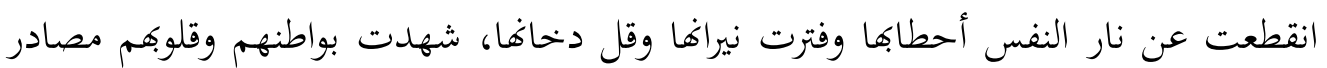

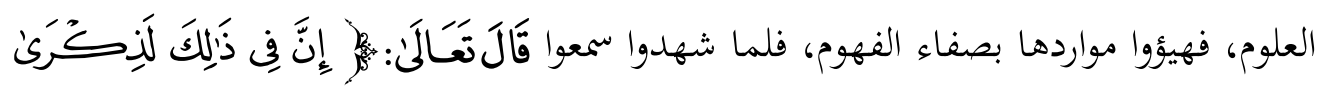

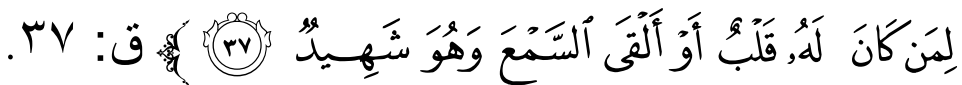

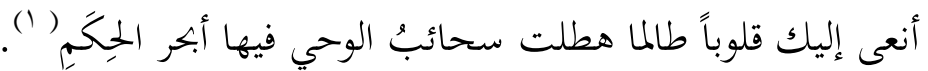
إلى أن قال :(وقال بعضهم: لمن كان له قلب بصير يقوى على التجريد مع الله اله تعالى والتفريد

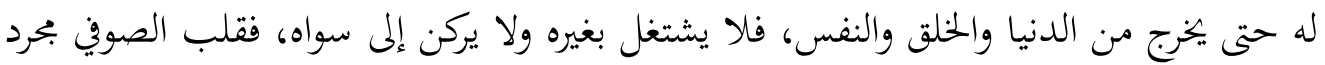

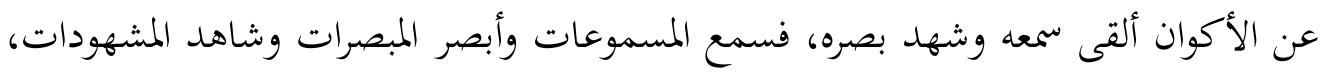

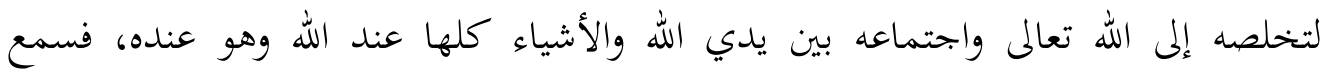

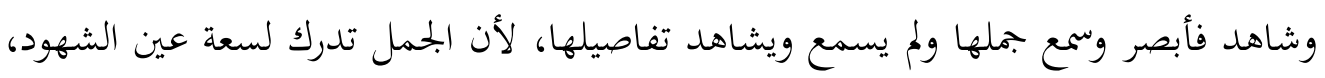

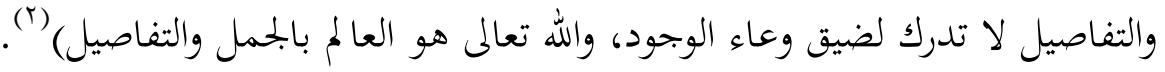

$$
\begin{aligned}
& \text { - كتاب عوارف المعارف (1 / ع 1) للسهروردي . } \\
& \text { r - عوارف المعارف (1 / ج 1 ) . }
\end{aligned}
$$




\section{IrA}

ثم يتبع كلامه قائلاً :(ومثل الذي وقع في أرض طيبة مثل المستمع الذي ينوي عمله فيفهمه ويعمل به ويجانب هواه، وهذا الذي جانب الهوى وانتهج سبيل الهدى هو الصوفي، لأن للهوى حلاوة، والنفس إذا تشربت حلاوة الهوى فهي تركن إليه وتستلذه، واستلذاذ الهوى هو الذي يخنق النبت كالشوك، وقلب الصوفي نازله حلاوة الحب الصافي، والحب الصافي تعلق الروح

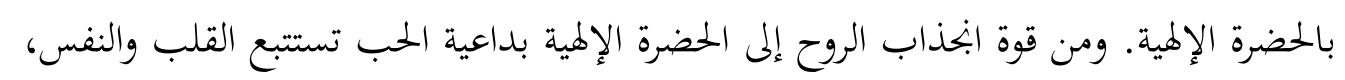

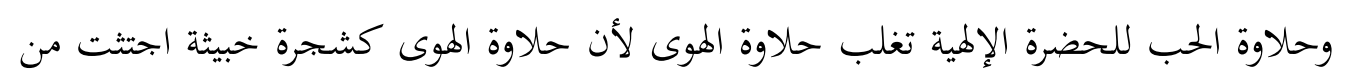
فوق الأرض ما لها من قرار لكوها لا ترتقي عن حد النفس، وحلاوة الحب كشجرة طيبة

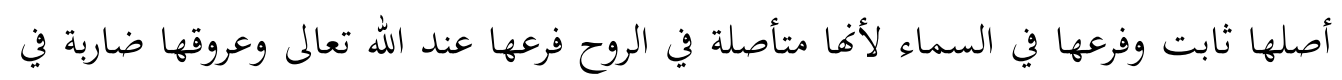

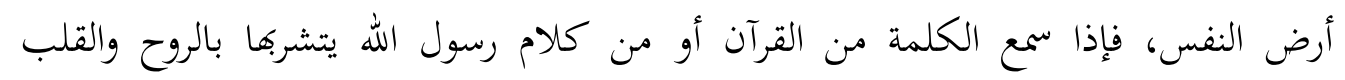
والنفس ويفديها بكليته ويقول:

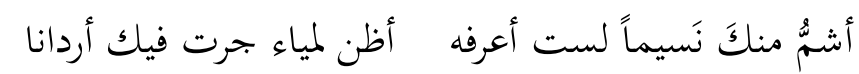

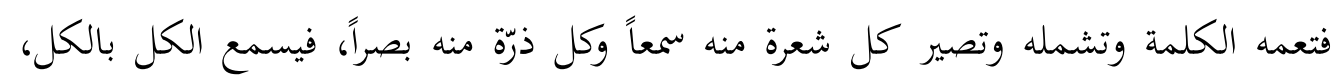
ويبصر الكل بالكل ويقول:

إن تأملتكم فكلي عيونُ أو تذكرتكم فكلي قلوبُ (1 ). ثم يقول في شأن المريدين بحاه الشيوخ :(واعلم أن للمريدين مع الشيوخ أوان ارتضاع وأوان

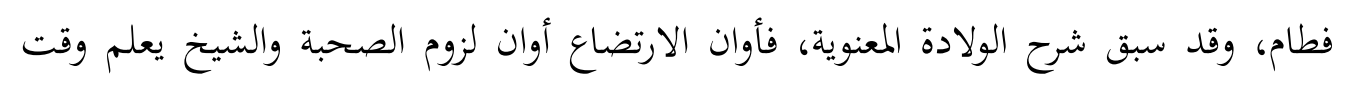
ذلك، فلا ينبغي للمريد أن يفارق الشيخ إلا بإذنه. قال الله تعالى تأديباً للأمة: قَّالَ تَعَالَّ:

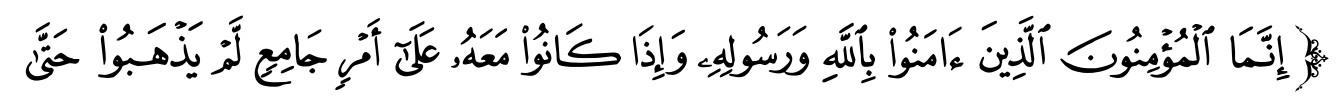

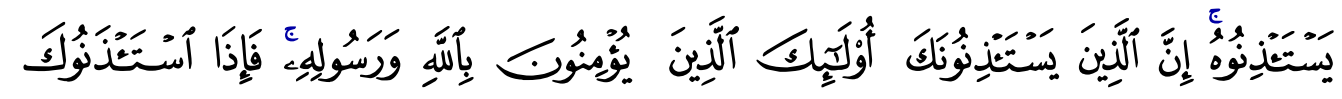

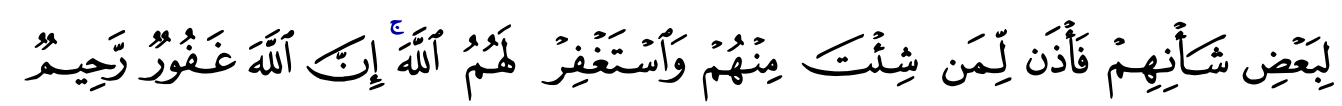

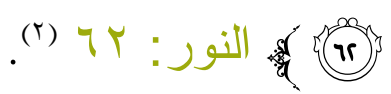

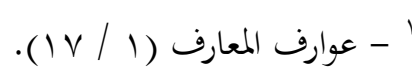

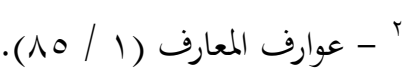




\section{9}

ومن كتبهم "كتاب نوادر الأصول من أحاديث الرسول" (لأبي عبد الله محمد بن علي بن

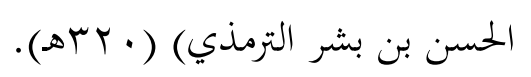

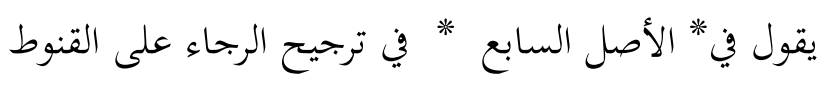

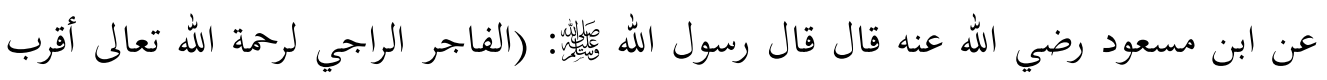

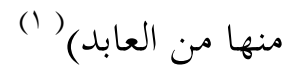
المقنط لجهله بالله بعد من رحمة الله وإنما رجاء العبد بالله على قدر معرفته بالله وعلمه بجوده وكرمه والقنوط من الجهل ألا يرى إلى قوله تعالى " و من يقنط من رحمة ربه إلا الضاء الضالون ". والمقنِّط إنما يقنط غيره لقنوطه فهو ضال عن ربه وما تغني العبادة مع الضلالة؟ قَالَّنَّالَّ:

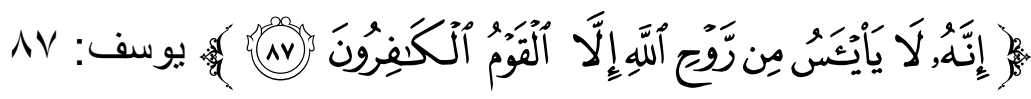

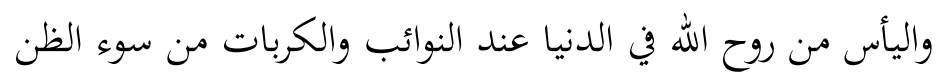

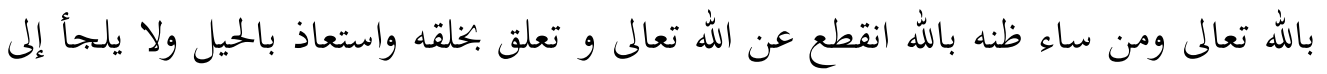

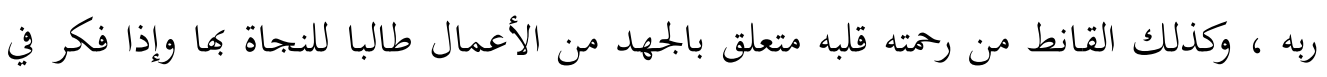

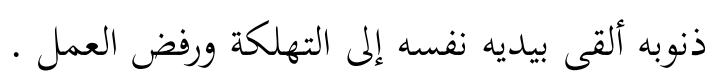

و روي عن الحسن البصري رحمه الله أنه سئل عن القنوط فقال: ترك فرائض الفي الله في السر معناه

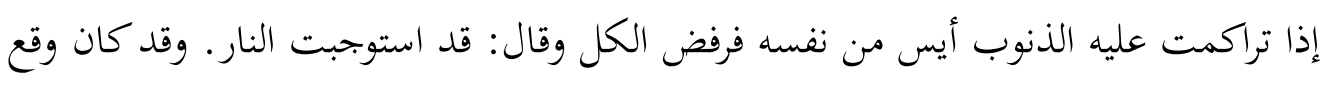

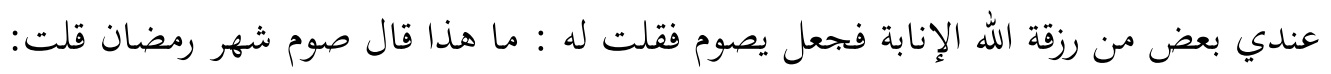

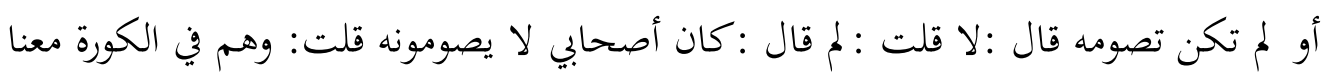

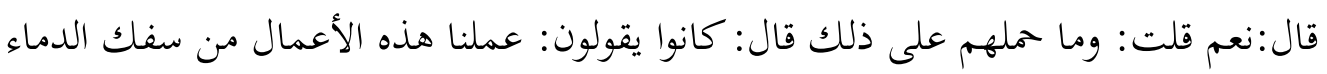

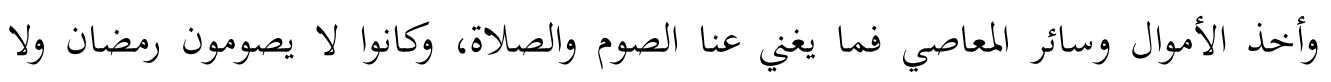

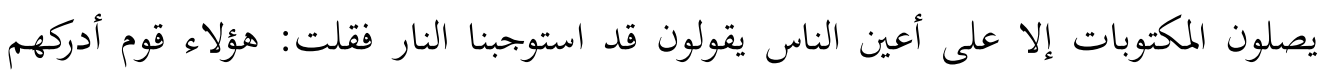

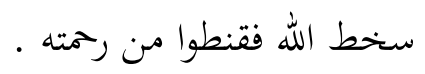

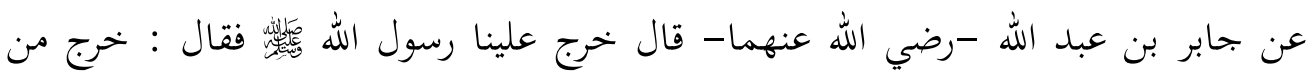

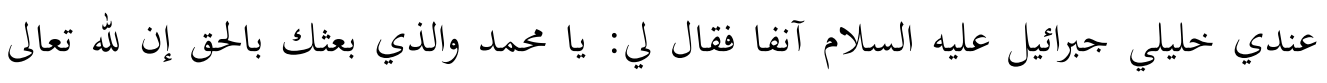

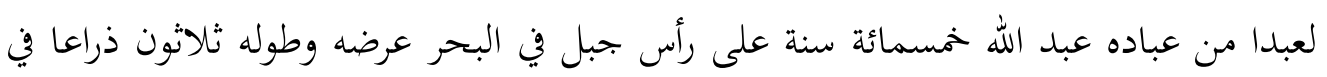

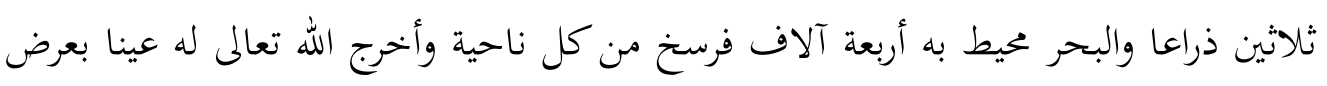

$$
\text { ' - ( موضوع ) انظر صحيح وضعيف الجامع الصغير (1/ }
$$




\section{Ir.}

الإصبع تبض بماء عذب فيستنع في أسفل ذلك الجبل وشجرة رمانة تخرج كل ليلة رمانة فتغذيه

يوما فإذا

أمسى نزل فأصاب من الوضوء وأخذ تلك الرمانة وأكلها، ثم قام لصلاته فسأل ربه - عز وجل - عند وقت الأجل أن يقبضه ساجدا وأن لا يجعل للأرض ولا شيء لشيء عليه يفسده عليه سبيلا حتى يبعثه ساجدا فقعل ذلك فنحن نمر به إذا هبطنا وإذا عرجنا وبند في العلم أنه يبعث يوم القيامة فيوقف بين يدي الله تعالى فيقول الرب عز وجل أدخلوا عبدي الجنة برحتي فيقول بل بعملي يا رب فيقول أدخلوا عبدي الجنة برحتي فيقول بل بعملي يا رب فيقول

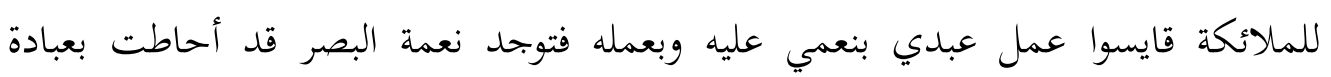

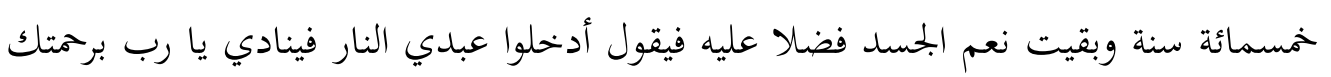
أدخلني الجنة فيقول ردوه فيوقف بين يديه فيقول يا عبدي من خلقك ولم تك شيئا فيقول : أنت يا رب فيقول:أفكان ذلك من قبلك أم برحتي فيقول : بل برحمتك فيقول من قواك

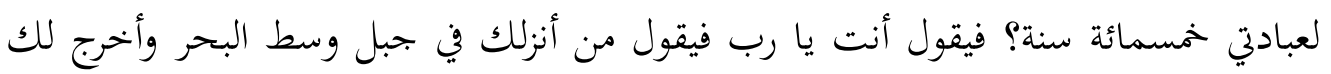
الماء العذب من الماء المالح وأخرج لك كل ليلة رمانة وإنما تخرج الشجرة في السنة مرة؟ وسألتني أن أقبضك ساجدا ففعلت ذلك بك ، فيقول : أنت يا رب، فيقول: فذلك رحمتي وبرحتي

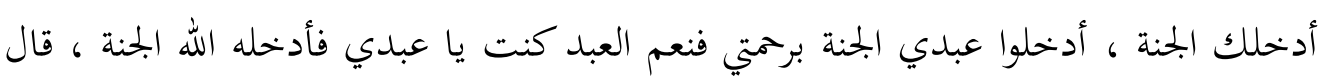

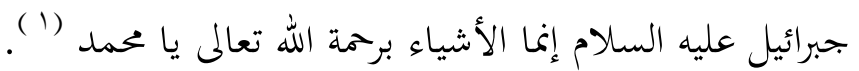

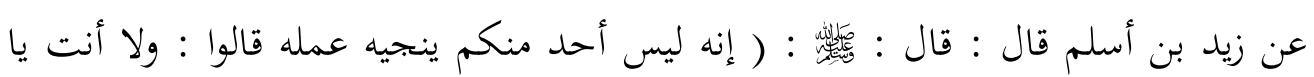

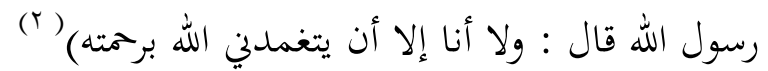

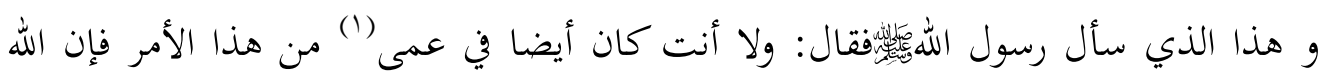

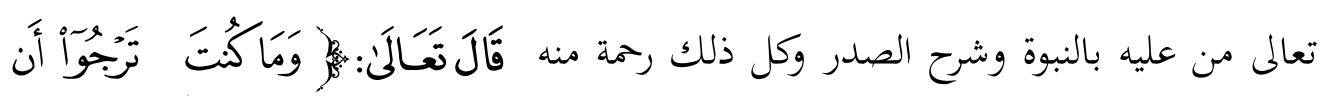

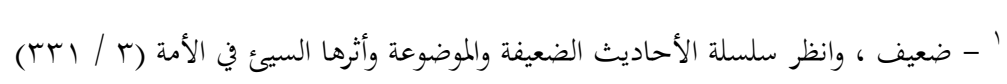

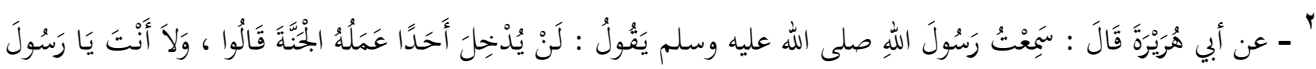

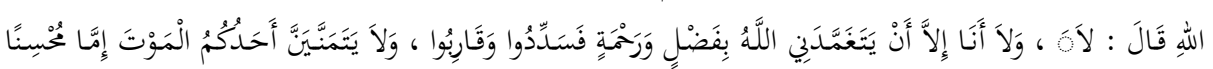

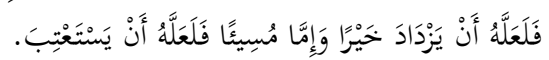

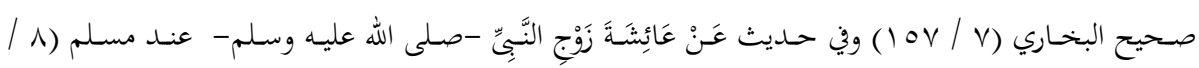

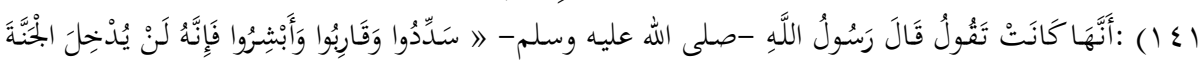

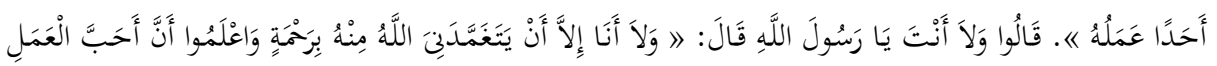

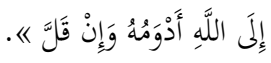




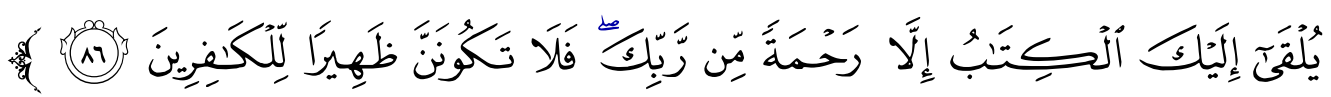
(القصص: الفصل الثالث : موقف الصوفية من إسناد الحديث . هناك فرق بيّن واضح بين الصوفية الأوائل ، عمن أتى بعدهم ، فلقد كان الأولون منهم ممن من إسنادئ كان يذهب مذهب الزهد والتقشف في أمور الدنيا له عناية بالسنة ، ويحرص على نظافة

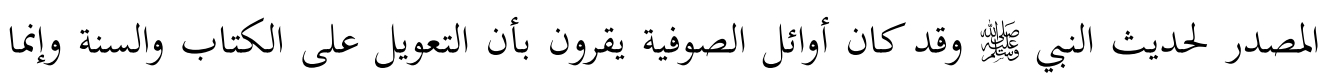
لبس الشيطان على بعضهم لقلة علمهم يقول الجنيد : قال أبو سليمان الداراني قال ربما تقع في نفسي النكتة من نكت القوم أياما فلا أقبل منه إلا بشاهدين عدلين الكتاب والسنة. وهذا الجنيد وهو من أصحاب الطريقة يقول : (مذهبنا هذا مقيد بالأصول الكتاب والسنة وقال أيضا علمنا منوط بالكتاب والسنة من لم يمفظ الكتاب ويكتب الحديث ولم يتفقه لا يقتدى به)، وقال -أيضا-:(ما أخذنا التصوف عن القيل والقال، لكن عن الجوع وترك الدنيا وقطع المألوفات والمستحسنات لأن التصوف من صفاء المعاملة مع الله سبحانه وتعالى وأصله

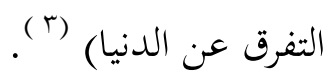
ونحن لانوافق الجنيد نِّيُّهُ في كل ما يقول و ولكن نستفيد من كلامه الفرق بين ما كانوا عليه من اتباع الكتاب والسنة ، وهؤلاء كانت مقاصدهم حسنة غير أهم على غير الجحادة وفيهم من فئن كان لقلة علمه يعمل بما يقع إليه من الأحاديث الموضوعة وهو لا يدري. وكان أبو عثمان سعيد بن إسماعيل النيسابوري، من جلة شيوخ القوم وعارفيهم وكان شديد الوصية باتباع السنة وتحكيمها ولزومها ،ولما حضرته الوفاة مزق ابنه قميصا على نفسه، ففتح أبو عثمان عينيه وهو في السياق فقال : يا بني خلاف السنة في الظاهر علامة رياء في الباطن

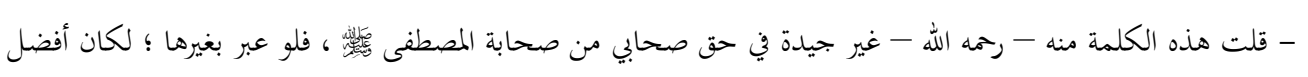

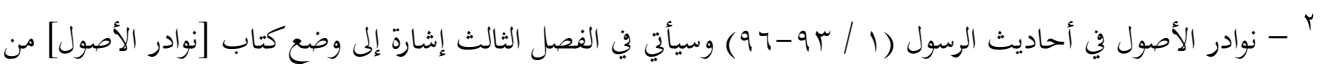

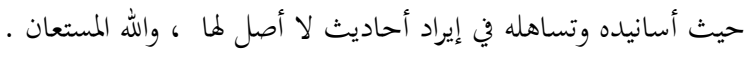

ك

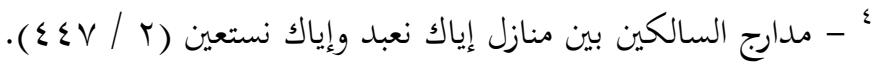


أما المتأخرون (1) منهم ممن كان يذهب إلى اتباع ما تهواه نفسه ، أو تمليه عليه خواطره التي اتخذها الثيطان له مسكناً ، وأصبح يتكلم عن العلم الظاهر والباطن غير مهتم بسلامة المنقول ، ويتحدث بأشياء يستحي أصحاب العقول السليمة من ذكرها، فجاء أبو عبد الرحمن السلمي، فصنف لهم كتاب السنن وبمع لهم حقائق التفسير ،فذكر عنهم فيه العجب في

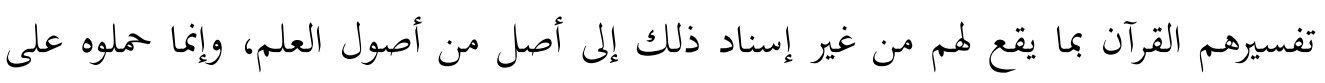
مذاهبهم

وصنف لهم أبو طالب المكي(7م مه) (قوت القلوب) فذكر فيه الأحاديث الباطلة وما لا

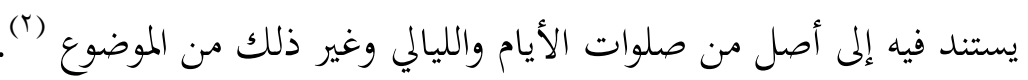
وما صنفه الترمذي فكأنه ابتداءً شرّع برأيه الفاسد ، فما وجه صيام شهرين متتابعين عند التوبة ولية ، وما فائدة قطع الفواكه المباحة وإذا لم ينظر في الكتب فبأي سيرة يقتدي وأما الأربعينية

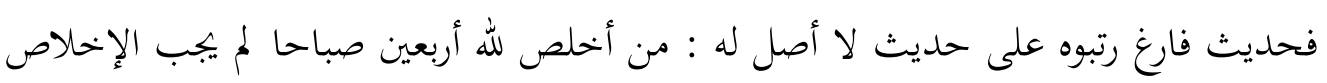
أبدا ،فما وجه تقديره بأربعين صباحا، ثم لو قدرنا ذلك فالإخلاص عمل القلب فما فئ بال (المطعم ؟!) ولم يكتف أهل هذا المنهج من المتصوفة بالتنفير من علم الشريعة والحديث بل جعلوا كشفهم، وما يزعمون نقله من العلم عن الله تبارك وتعالى حاكما على إسناد الحديث فيصححون ما شاءوا من الأحاديث، وإن كانت ضعيفة عند علماء الحديث والسنة، ويضعفون ما شاءوا منها، وإن كانت ثابتة صحيحة حسب الموازين العلمية الدقيقة التي تعارف عليها علماء الحديث ومصطلحه، والتي هي بكق مفخرة الإسلام، فليس عند أمة من أمم الأرض قديمًا وحديثًا تثبت في النقل على النحو الذي درج عليه علماء هذه الأمة في التعرف على الحديث الصحيح من الضعيف، وبذلك ولله الحمد سلم دين الأمة من دخول أقوال الزنادقة والملاحدة

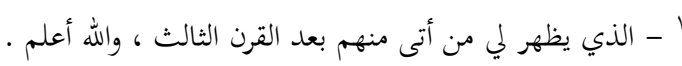

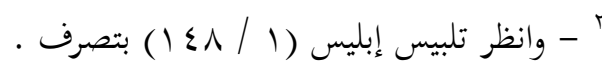
$=$

روي عن أبي أيوب: (من أخلص لله أربعين يوما ظهرت ينابيع الحكمة من قلبه على لسانه)

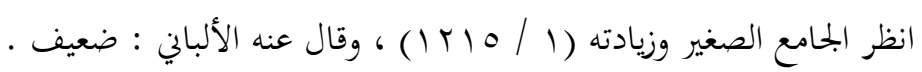




\section{Irr}

لقد عمد رؤساء المتصوفة إلى هدم الإسناد في الحديث، وهو مفخرة الإسلام بحق، وذلك

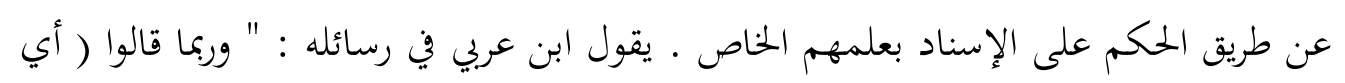
علماء الشريعة ) إذا عاينوهم ( أي عاينوا علماء الصوفية ) يتكلمون بمواجيدهم مع أصحابهم : دين مكتوم، دين مشؤم، وما عرفوا جهات الدين . وهؤلاء ما تكتموا بالدين فقط، وإنما

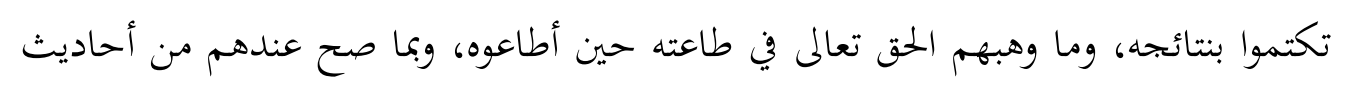

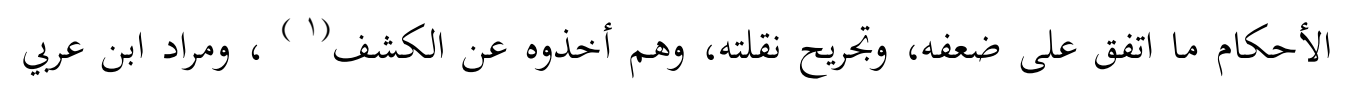

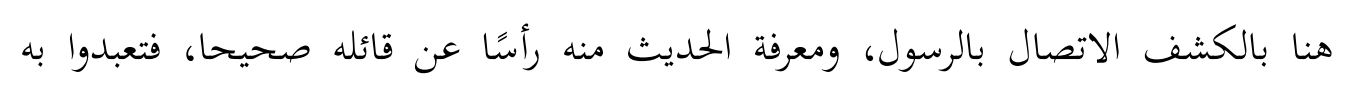

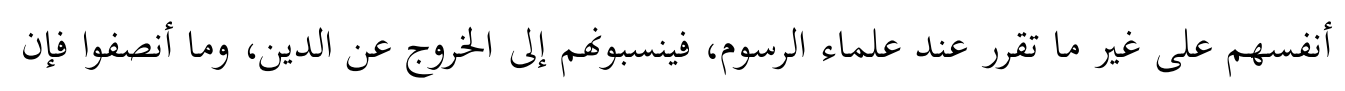
للحق وجوهًا يوصل إليه منها هذا أحدها، ورب حديث قد صحححوه واتفقوا عليه، وليس

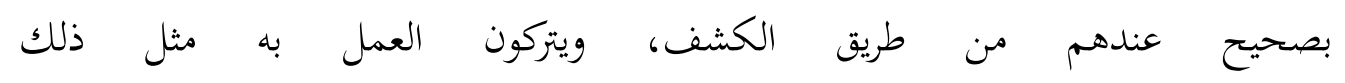

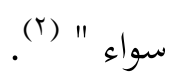

ومن هذا يتبين الفرق بين الصوفية المتقدمين منهم عن المتأخرين ممن يزعم هذا الزعم ·

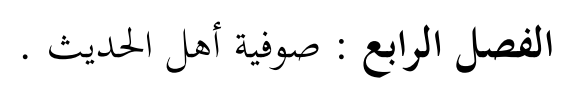

عندما يتأمل المتأمل في تراجم السلف الصالح وأعني أهل الحلديث منهم خاصة ، فإننا بند في

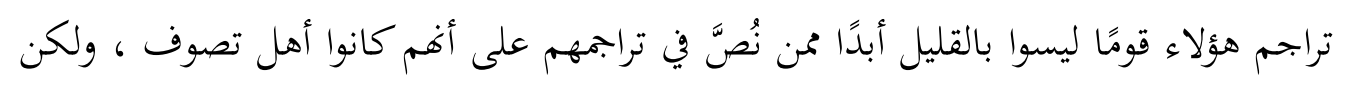
السؤال الذي ينبغي أن يتبادر إلى الذهن

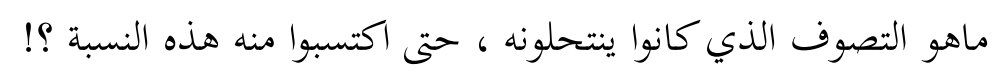

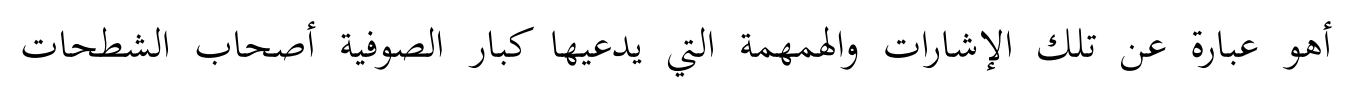

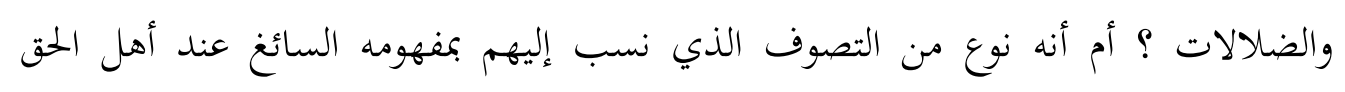

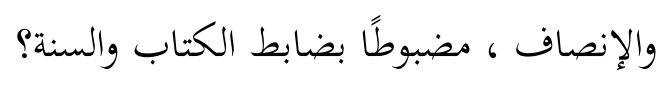
والذي يظهر - والعلم عند الله - أن كال النوعين موجود ، ولكن تختلف حال كل نوع بحسب المشرب الذي استقى منه صاحبه ، فهناك ممن كان يسمى بالصوفي ، وله أحاديث في الصحاح والسنن ، وهناك ممن سمي بالصوفي ولكنه زلت به القدم وحادت به عن طريق الحق وجادة

$$
\text { ' '- - هو انكشاف حجاب القلب ورؤيته أشياء من الغيب زعم الصوفية أنه يكصل لهم . }
$$




\section{I}

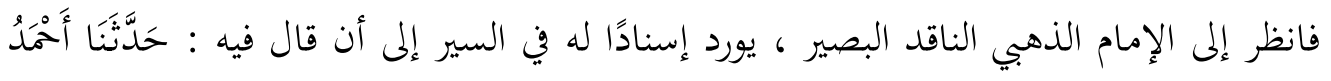

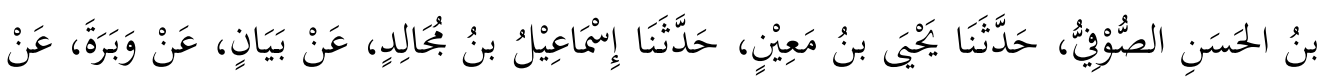
هَمَّام، قَالَ:

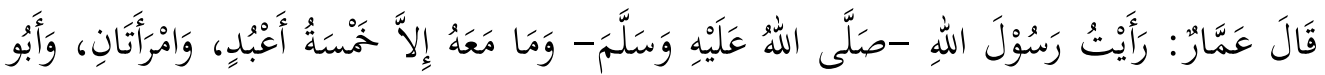
بَكْرِ

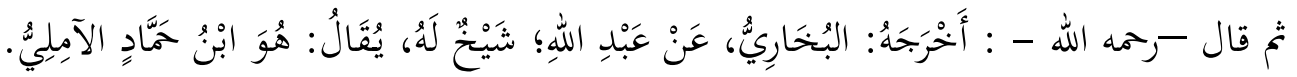

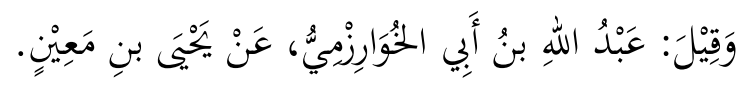

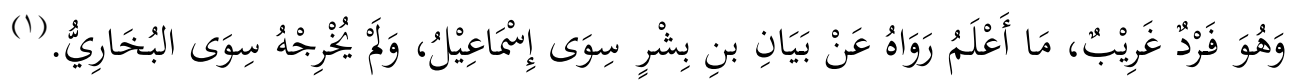

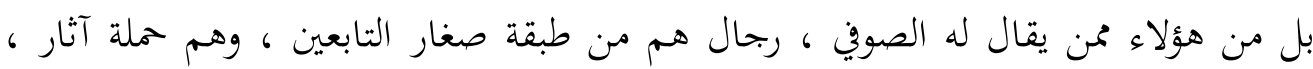

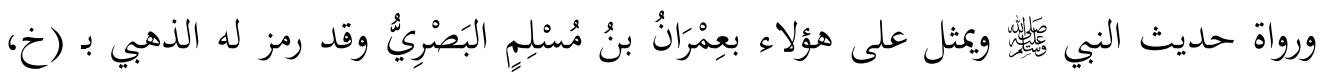

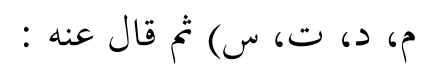

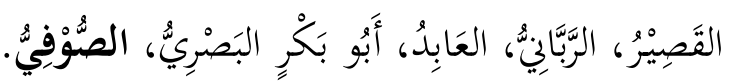

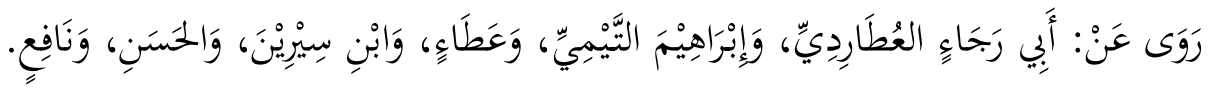

$$
\begin{aligned}
& \text { وَقِيّْلَ: رَوَى عَنْ أَنَسِ. } \\
& \text { وَعِعَدادُه فِي صِغَارِ التَّابِعِيْنَ. (r) }
\end{aligned}
$$

فمن المحدثين رجال نُسبوا إلى هذه الطائفة ، والحق الذي نعتقده في مثل رجال القرون الثلاثة

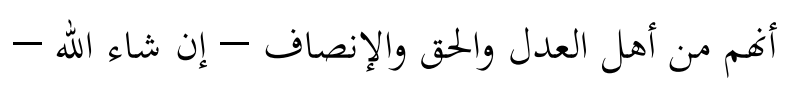

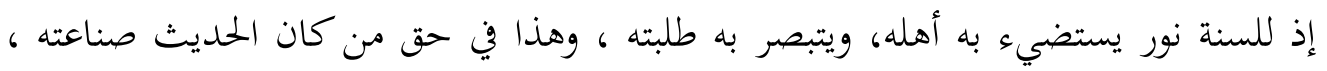
والتنقل في حفظه وتنقيته ضيعتُه .

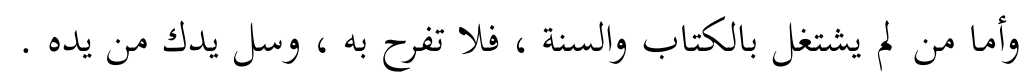

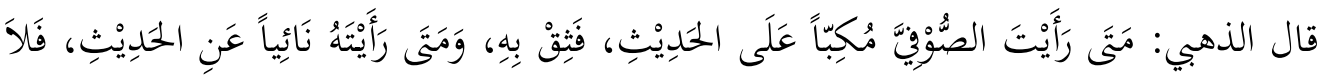

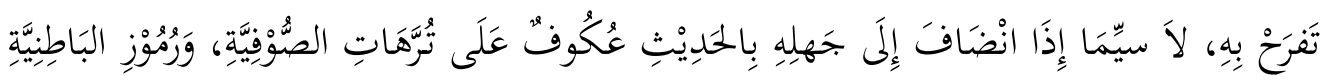

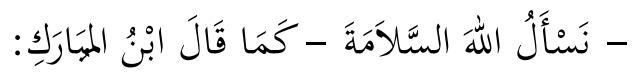

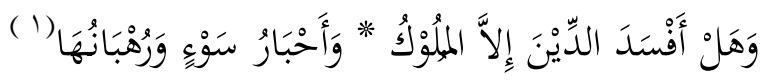

$$
\begin{aligned}
& \text { - سير أعلام النبلاء (1 / IVY) }
\end{aligned}
$$

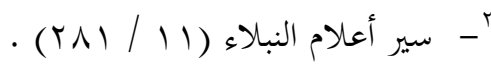




\section{Iro}

وعليه فعندما تتأمل كتب التراجم المسندة بتحد أسانيدها طافحة بذكر هذه النسبة في حملة

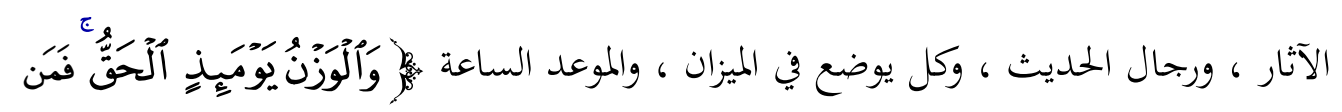

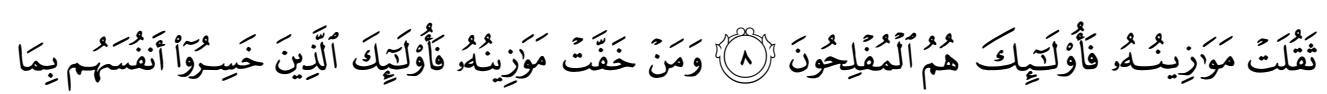

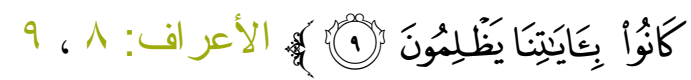




\section{Iry}

الفصل الخامس: شبه الصوفية .

حينما نقف متأملين أمام أي فرقة من الفرق التي تنتسب إلى الإسلام بجد أن من أبرز أسباب انخرافها ، ومن وسائل الشيطان في إغوائها :شبهات عرضت للقوم لم تستطع قلوبهم لها دفعا ، ولم يززقوا من البصيرة بتحاهها منعا . وإن من هذه الطوائف الزائغة عن الحق ، فرقة الصوفية التي تشربت من الشبهات ما تشربت ، وتضلعت من مستنقعات الشيطان حتى ارتوت ومما ادعاه الصوفية من الشبه والخيالات :

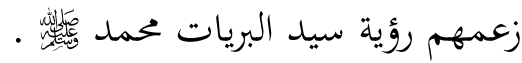

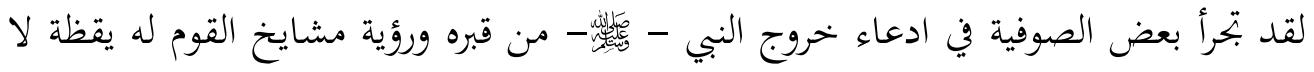
مناماً في الحياة الدنيا والتلقي منه، على اختلاف بينهم في كيفية هذه الرؤية (1)

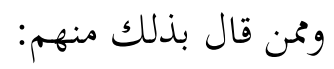
ابن حجر الهيتمي في "الفتاوى الحديثية" والسيوطي في "تنوير الحلك في إمكان رؤية النبي صلى الله عليه وسلم - والملك" ضمن"الحاوي للفتاوي" ، وأبو المواهب الشاذلي كما في "الطبقات الكبرى" للشعراني ، والشعراني كما في "الطبقات الصغرى" ، وأحمد التيجاني وخلفاؤه كما في "رماح حزب الرحيم على نهور حزب الرجيم"، ومن المتأخرين: خوجلي بن عبد الرحمن بن إبراهيم كما في "طبقات ابن ضيف الله" ، ومحمد بن علوي المالكي في "الذخحائر المحمدية" ، ومحمد فؤاد الفرشوطي في "القرب والتهاني في حضرة التداني شرح الصلوات المحمدية للسادة

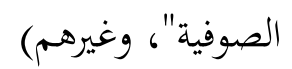

وسوف أنقل رد علماء السنة على هذه البدعة والشبهة المدعاة من غلاة الصوفية الضالين .

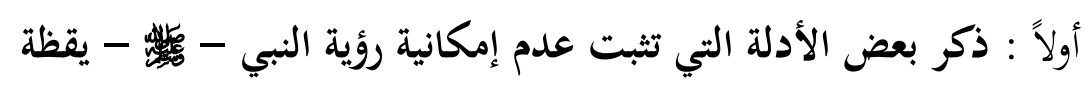
قال الشيخ محمد أحمد لوح :

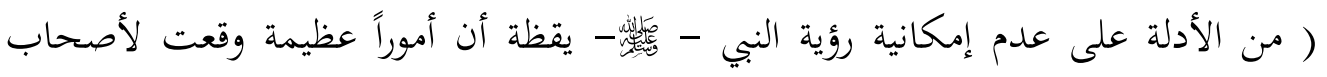
رسول الله - - ريّلة - وهم أفضل الأمة بعد نبيها كانوا في حاجة ماسة إلى وجوده بين أظهرهم ولم

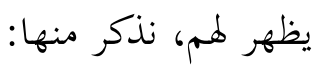
' - موسوعة الرد على الصوفية (YT / / ) ) ، وسوف أنقل منها بقية ما يتعلق بهذه الشبهة . 


\section{ITV}

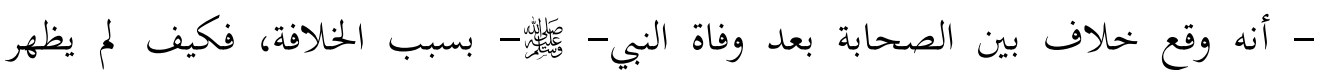
لأصحابه ويفصل النزاع بينهم.

- اختلاف أبي بكر الصديق مع فاطمة -رضي الله عنهما -على ميراث أبيها فاحتجت

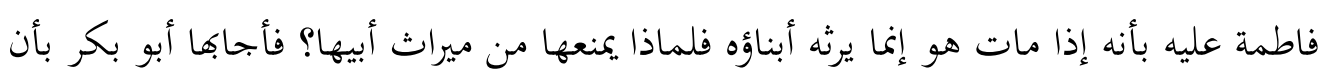

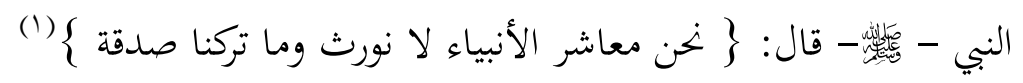

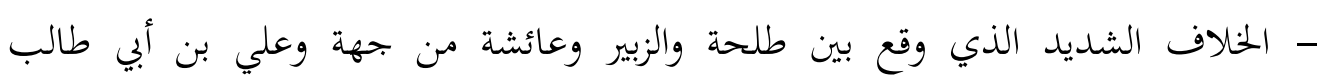

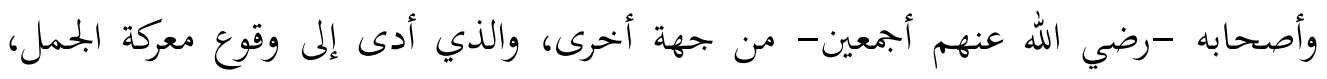

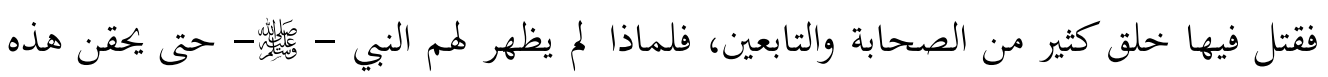
الدماء؟

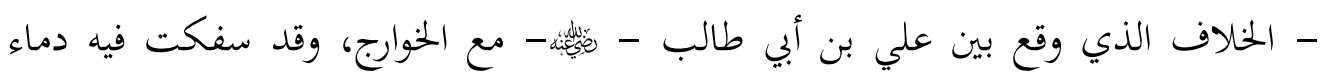

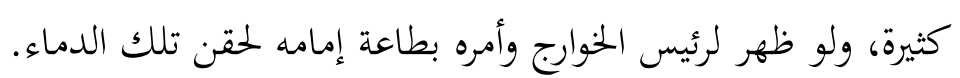

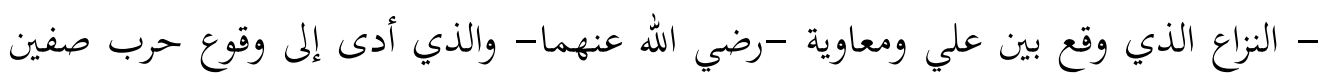

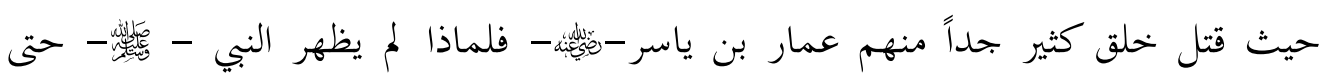

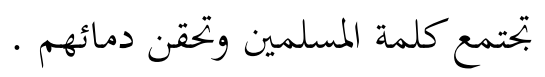

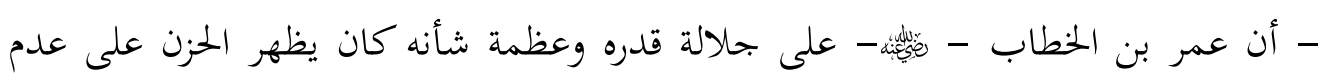

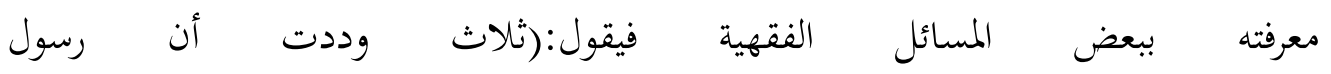

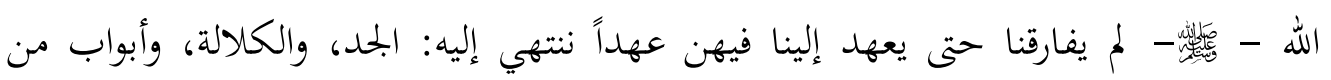

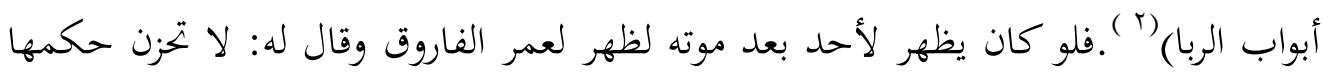
كذا وكذا) اهـ .

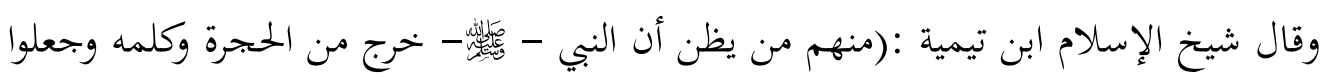
هذا من كراماته ، ومنهم من يعتقد أنه إذا سأل المقبور أجابه.

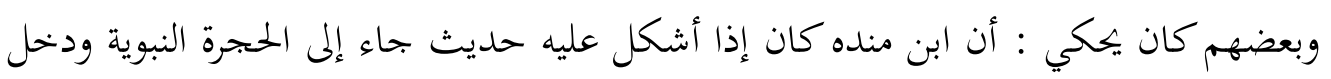

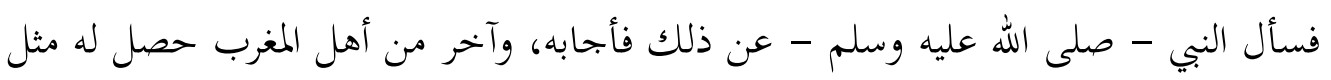

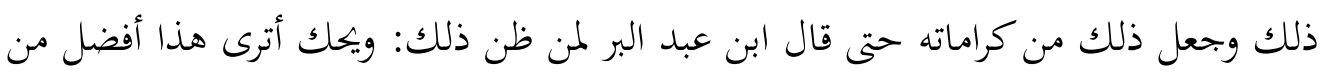

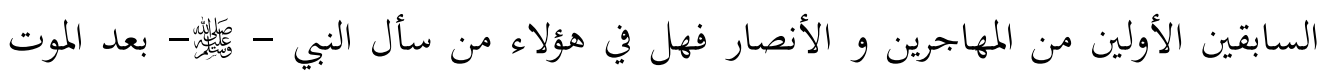

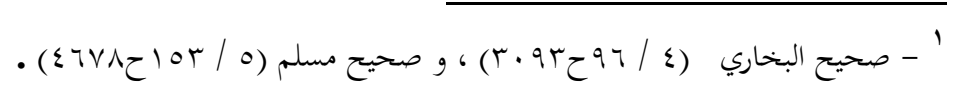

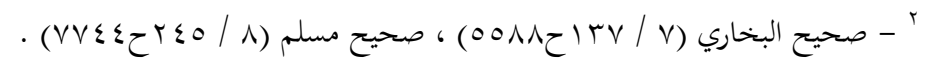




\section{HA}

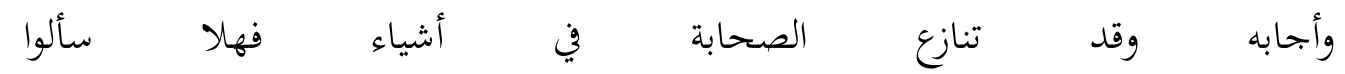

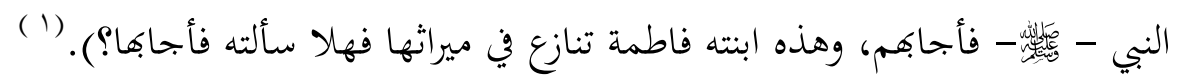

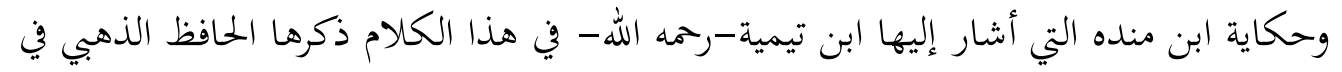

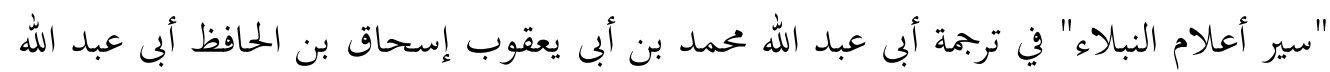

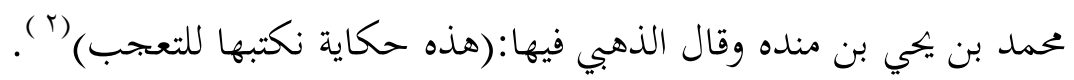

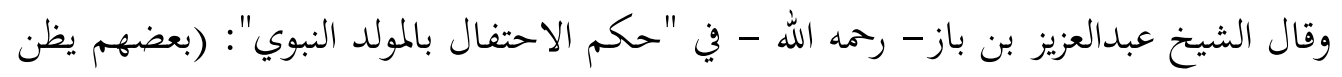

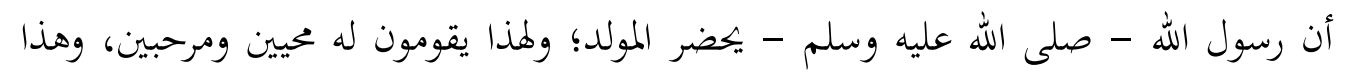

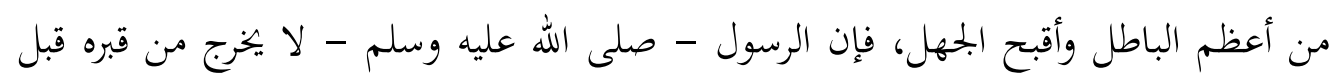

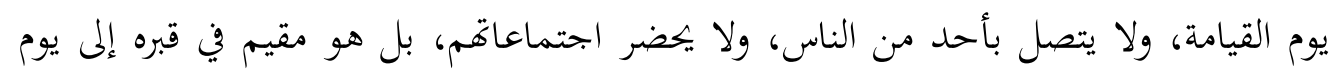

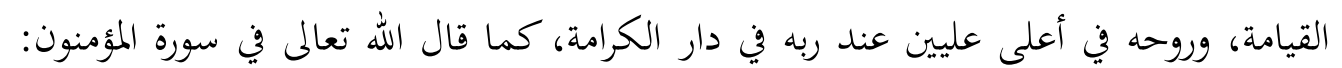

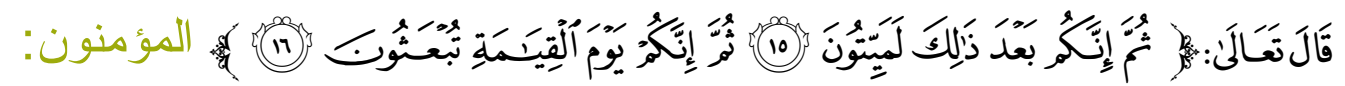

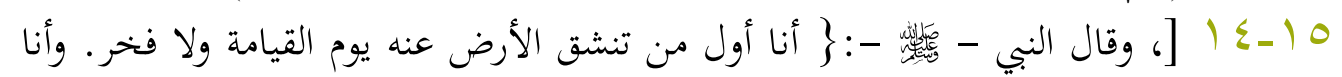

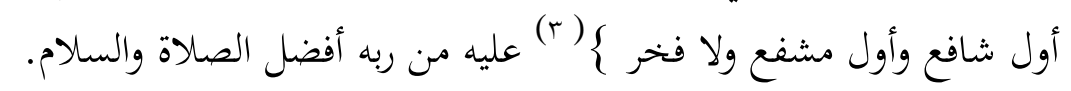
ومن شبه الصوفية الاستفتاح بصعاليك المهاجرين .

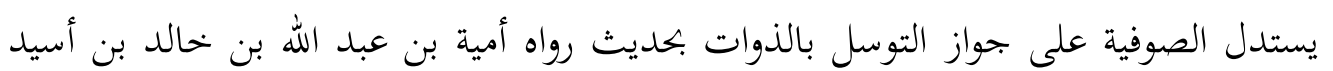

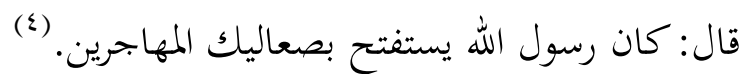

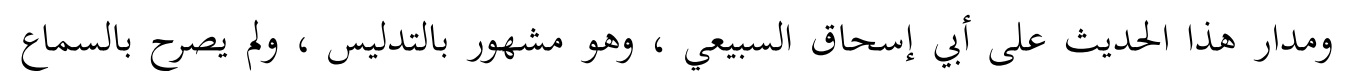
كمن فوقه في أي من طرق الحمديث الحديث.

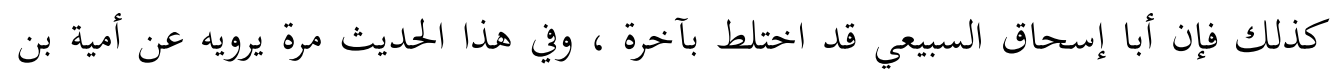

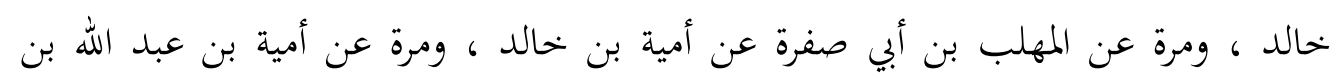

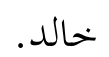

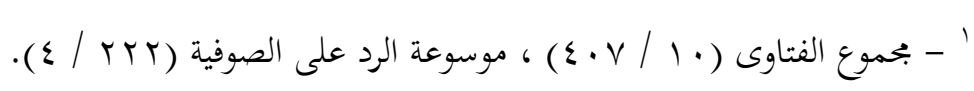

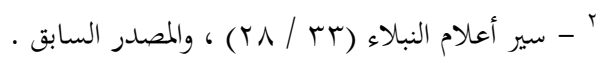

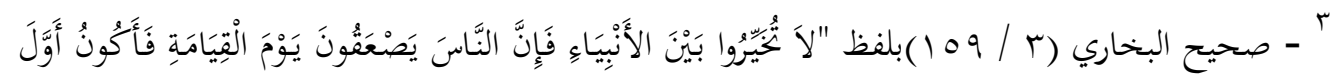

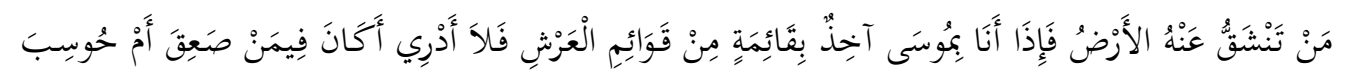

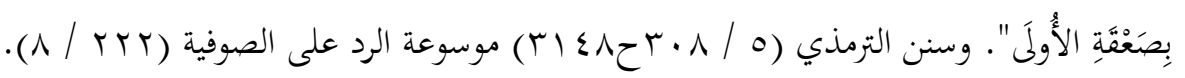

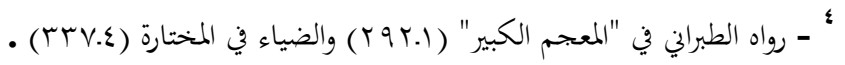




\section{$14 q$}

كذلك فإن "أمية بن خالد" لم تثبت صحبته ، فالحديث لو سلم من تدليس واختلاط أبي

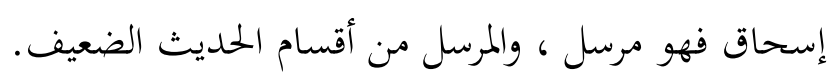

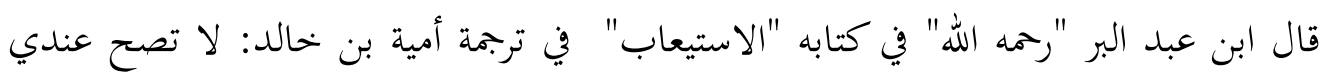
صحبته، والحديث مرسل. وقال الحافظ ابن حجر العسقلاني "رحمه الله" في كتابه "الإصابة": ليست له صحبة ولا رواية. (1)

ولو صح الحديث فإن معناه مخالف لما يقول به الصوفية ، قال القرطبي "رحه الله": وفي الحديث

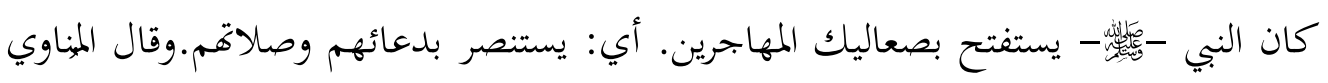
في شرح الجامع الصغير قوله: يستنصر بصعاليك المسلمين. أي :يطلب النصر بلدعاء فقرائهم تيمناً بهم ، .. قال القاري: أي بفقرائهم وببركة دعائهم (r).

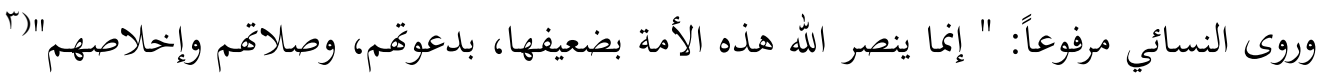

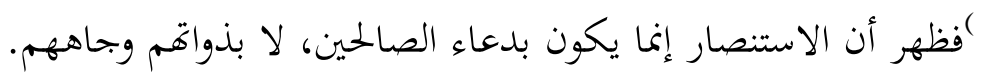

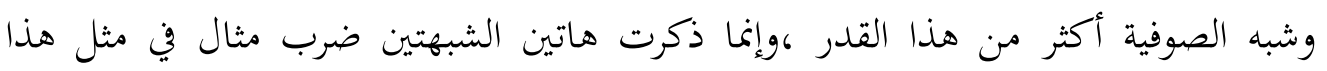
البحث المختصر . 


$$
\text { الفصل السادس: موقف العلماء من التصوف . }
$$

لقد اختلفت مواقف العلماء بتحه المعتقد الصوفي إلى ثلاث طوائف ذكرها

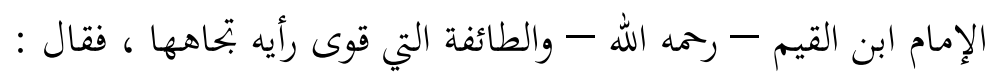

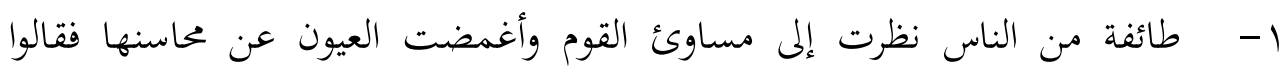
بضلال الصوفية وردوا كلامهم سواءً ما وافق الكتاب والسنة أو خالفهما وهذه الطائفة كما يقول ابن القيم: (حجبت عن محاسن هذه الطائفة ولطف نفوسهم وصدق معاملتهم فأهدروها لأجل هذه الشطحات وأنكروها غاية الإنكار وأساءوا الظن بهم).

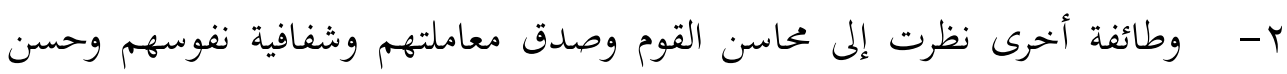

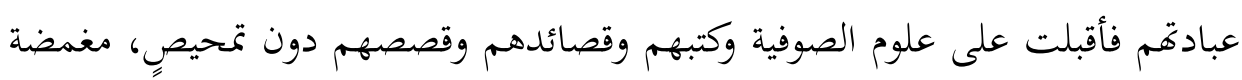

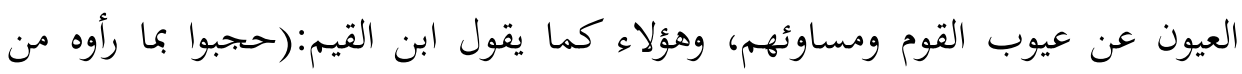
محاسن القوم وصفاء قلوكم وصحة عزائمهم وحسن معاملتهم عن رؤية شطحاتم ).

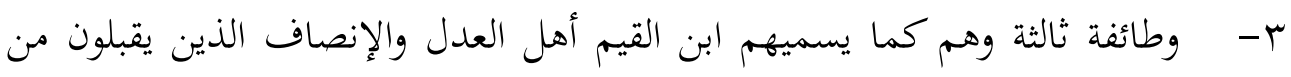

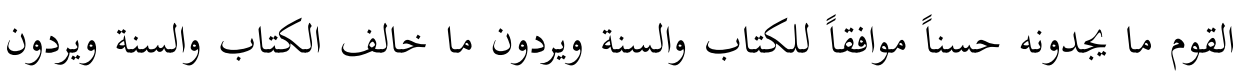
على شطحات القوم ، وهذا الموقف هو الذي يجب أن يقفه كل مسلمابل مسلم ،فلا تحملنا

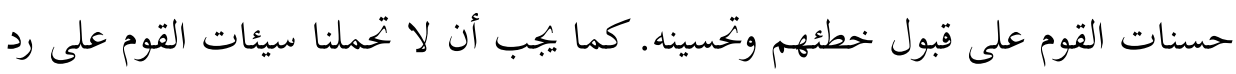
حق ذهبوا إليه أو قالوا به، بل الحكم العدل الذي بيننا هو الكتاب والسنة قَّالَ تَعَالَّ:

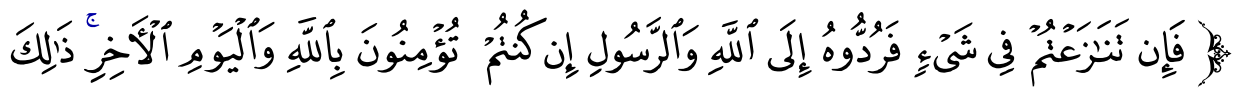

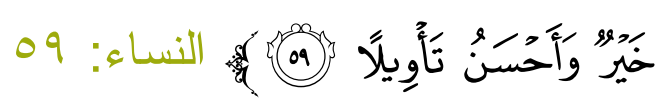

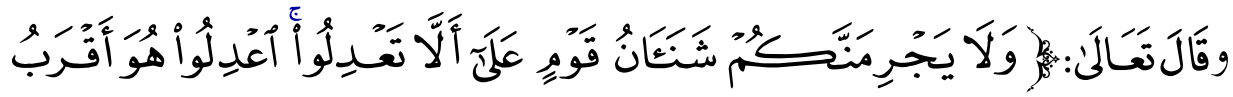

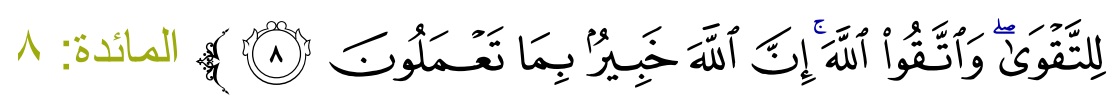

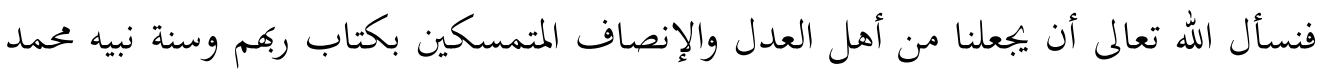
صلى الله عليه وسلم. (1)

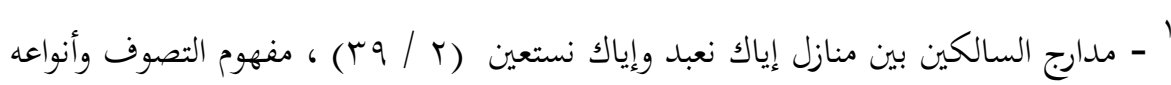

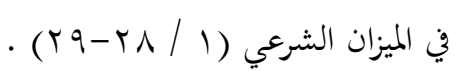


الحمد لله أهل الحمد والثناء ، والصلاة والسلام على خير الأنام وسيد الأنبياء ، محمد بن عبد

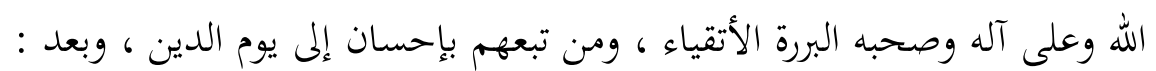

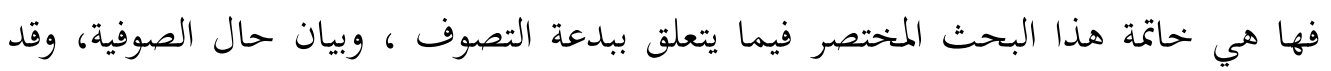
قضيت في إعداده الأيام والساعات ، حتى تم بناؤه على هذه الميئة . وإن واضع حجر أساسه ، ومنشئ الفكرة صاحب السعادة فضيلة الشيخ الأستاذ الدكتور موفق بن عبد الله - حفظه الله ورعاه- والذي تشرفنا بتدريسه لنا في السنة المنهجية من

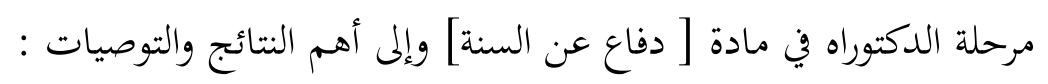
1- أن مفهوم التصوف مفهوم قديم ، وقد ظهر في القرون المفضلة منها.

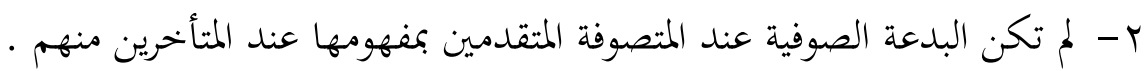
ץ- أن الغالب في متصوفة المتقدمين ، كان مفهوم التصوف عندهم ، هو الزهد في الدنيا والإقبال على الآخرة .

ع - - هناك علاقة قوية بين الصوفية والشيعة حتى في أصولهم الإعتقادية ، وإن اختلفت بينهم بعض مظاهرها . مان.

ه- ظهر للباحث أن كبار الصوفية الغالين ، من غير العرق العربي ، فكأفم فرس دخلاء

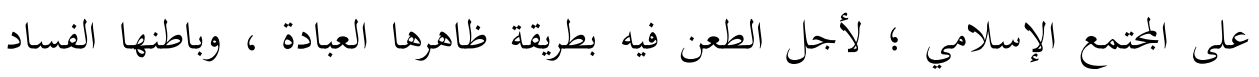
والإبادة .

ولذا أوصي بدراسة هذه البدعة وفهم طرقها الزائفة الزائغة عن الحق ؛ لأجل تحذير المحتمع من كيدهم وشرهم والله أعلم وهو الهادي إلى سواء السبيل ، وصلى الله وسلم وبارك على عبده ورسوله محمد والحمد لله رب العالمين وعلى آله وصحبه وسلم . 


\section{$1 \leqslant r$}

فهرست المصادر

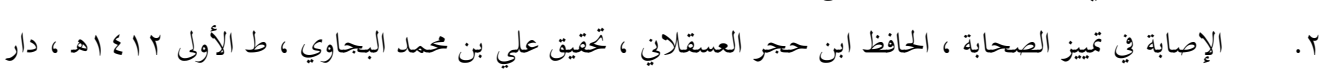

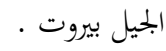
r. أصول مذهب الشيعة الإمامية الاثني عشرية عرض ونقد ، ناصر بن ع. أصول وتاريخ الفرق الإسلامية ، جمع وترتيب مصطفى محمد مصطفى. ه. الاعتصام ، العلامة إبراهيم بن موسى الشاطبي .

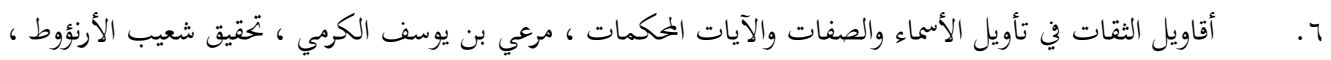

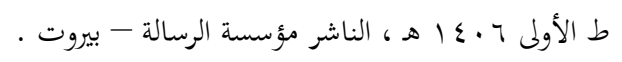

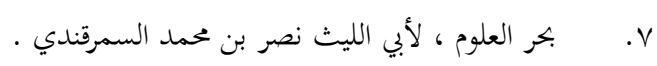

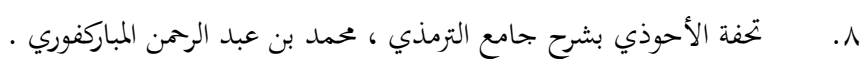
9. التصوف المنشأ والمصادر ، إحسان إلهي ظهير .

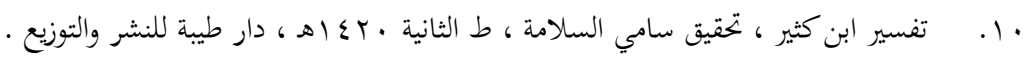

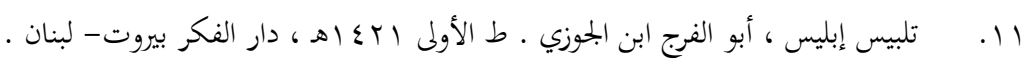

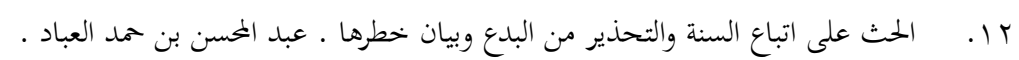

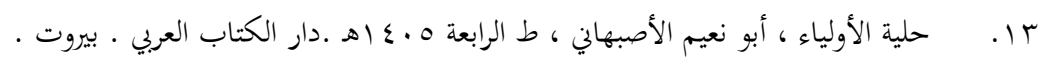

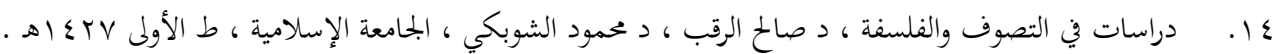

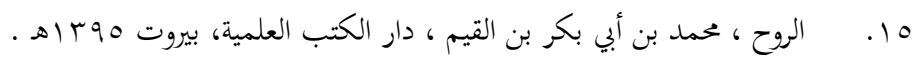

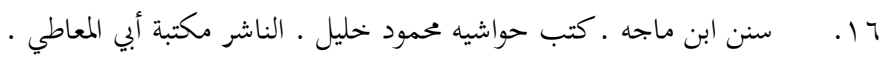

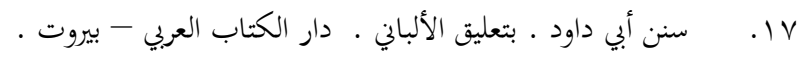

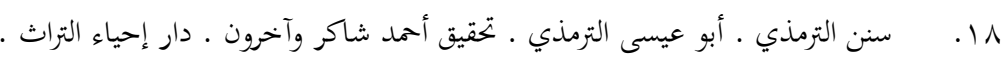

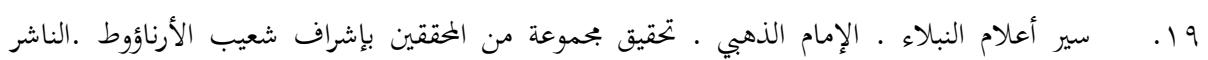
مؤسسة الرسالة .

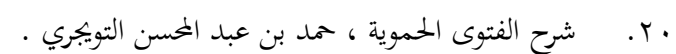

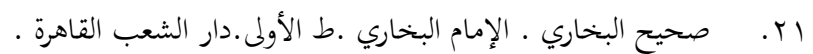

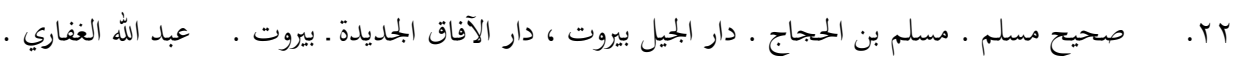

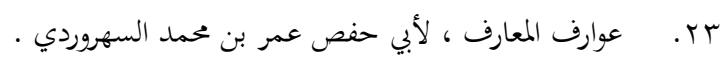

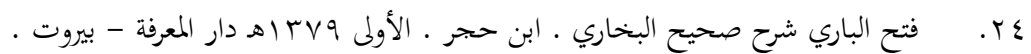

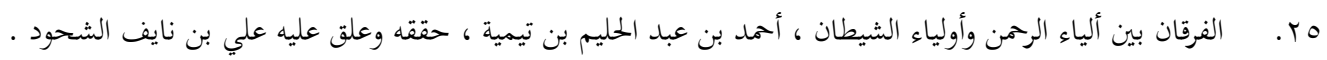

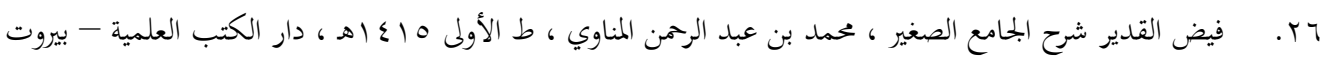

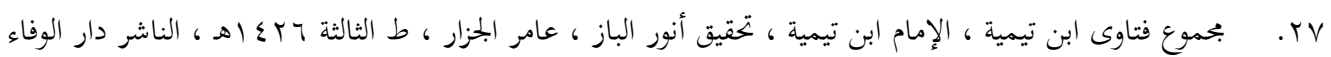
م r. مدارج السالكين بين منازل إياك نعبد وإياك نستعين ، أبو عبد الله بن القيم ، تحقيق محمد بن حامد فقي ، ط الثانية

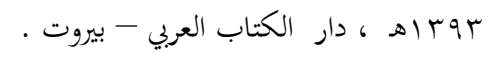




\section{$1 \leqslant r$}

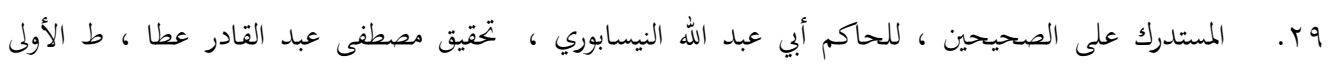

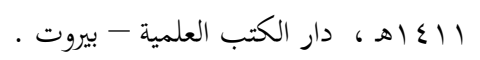

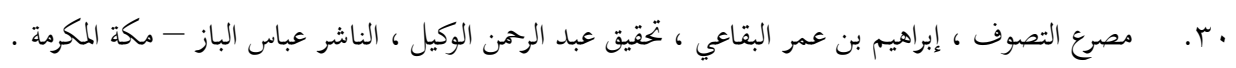

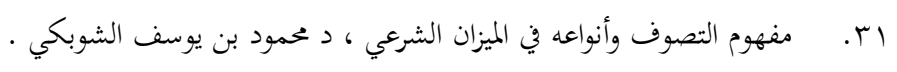

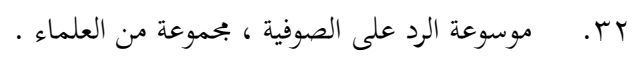

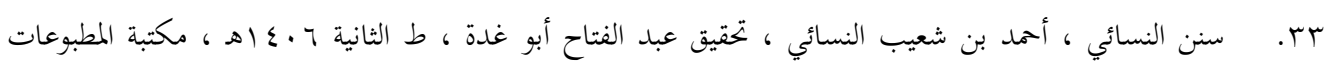

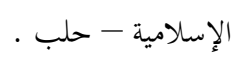

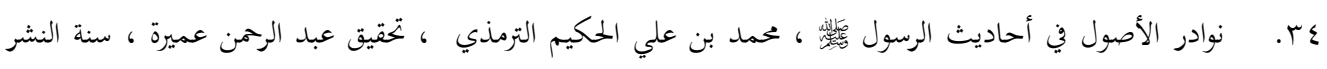
ب99 ام ، دار الجيل - بيروت . 